\title{
SYNTHESIS OF NATURAL FLOWS AT SELECTED SITES IN AND NEAR THE MILK RIVER BASIN, MONTANA, 1928-89
}

By Lawrence E. Cary and Charles Parrett

U.S. GEOLOGICAL SURVEY

Water-Resources Investigations Report 95-4022

Prepared in cooperation with the BUREAU OF RECLAMATION 


\section{U.S. DEPARTMENT OF THE INTERIOR \\ BRUCE BABBITT, Secretary}

U.S. GEOLOGICAL SURVEY

Gordon P. Eaton, Director

For additional information write to:

Copies of this report may be purchased from:

District Chief

U.S. Geological Survey

428 Federal Building

301 South Park Avenue

Drawer 10076

Helena, MT 59626-0076
U.S. Geological Survey

Earth Science Information Center

Open-File Reports Section

Box 25286, Mail Stop 517

Denver Federal Center

Denver, CO 80225 


\section{CONTENTS}

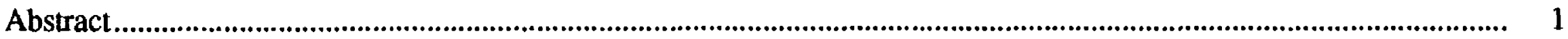

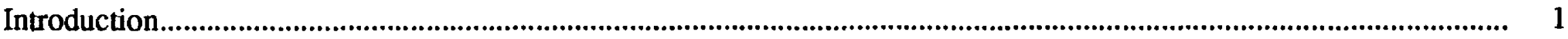

Synthesis of natural flows ................................................................................................................................... 4

Streamflow record extension ...................................................................................................................................... $\quad 7$

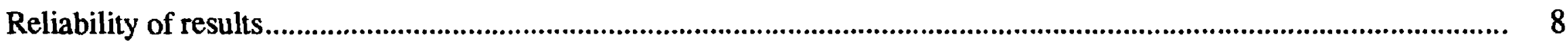

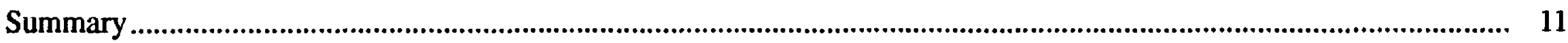

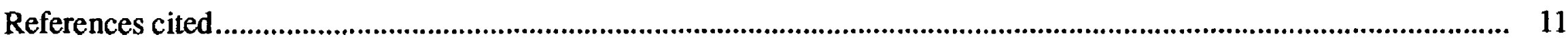

Supplemental data .............................................................................................................................................. 13

\section{ILLUSTRATIONS}

Figure 1. Map showing location of the St. Mary River Basin in Montana and Milk River Basin, streamflow accounting-model nodes, and streamflow-gaging stations used in data synthesis and extension of records

2. Graphs showing distribution of dimensionless monthly natural flows for two accounting-model nodes on the Milk River compared to distribution of dimensionless monthly flows for the North Fork Sun River near Augusta, Mont., and Poplar River near Poplar, Mont.

3. Graph showing comparison of means of synthesized monthly natural flows for the Milk River at mouth with means of recorded monthly flows for Milk River at Nashua. (1) 8 8 1 3 


\section{TABLES--Continued}

Page

Table 16. Synthesized streamflow volumes for Milk River at Vandalia diversion dam, Montana, 1928-89, in acre-feet.

17. Synthesized streamflow volumes for Milk River at mouth, Montana, 1928-89, in acre-feet.

\section{CONVERSION FACTORS}

\begin{tabular}{rcl}
\hline Multiply & By & To obtain \\
acre & & \\
acre-foot $\left(\mathrm{acre}^{-\mathrm{ft}}\right)$ & 0.4047 & hectare \\
mile $(\mathrm{mi})$ & 1,233 & cubic meter \\
cubic foot per second & 0.028317 & cubic meter per second \\
square mile $\left(\mathrm{mi}^{2}\right)$ & 1.609 & kilometer \\
\hline
\end{tabular}




\title{
SYNTHESIS OF NATURAL FLOWS AT SELECTED SITES IN AND NEAR THE MILK RIVER BASIN, MONTANA, 1928-89
}

\author{
By Lawrence E. Cary and Charles Parrett
}

\section{Abstract}

Natural monthly streamflows were synthesized for the years 1928-89 at 2 sites in the St. Mary River Basin and 11 sites in the Milk River Basin in north-central Montana. The sites are represented as nodes in a streamflow accounting model being developed by the Bureau of Reclamation for the Milk River Basin. Recorded flows at most sites have been affected by human activities, including reservoir storage and irrigation diversions. The flows at the model nodes were corrected for the effects of these activities to obtain synthesized flows. Recorded data at some sites do not include the entire study period, or are only seasonal. The synthesized flows at these sites were extended using a statistical technique.

The methods of synthesis varied, depending on upstream activities and information available. Flows at sites in the St. Mary River Basin and at Milk River at Eastern Crossing of International Boundary previously had been synthesized. However, at one St. Mary River site and at Milk River at Eastern Crossing, previously synthesized total natural flow for the period November through March or April needed to be disaggregated into monthly flows. The flows at mainstem sites downstream from the Milk River at Eastern Crossing were synthesized by adding synthesized natural runoff from intervening drainage areas to natural flows for Milk River at Eastern Crossing. Natural runoff from intervening drainage areas was estimated by multiplying recorded flows at selected index gaging stations on tributary streams by the ratio of the intervening drainage area to the combined drainage area of the index stations. The recorded flows for Milk River at Western Crossing of International Boundary and for Peoples Creek near Dodson, Montana, were assumed to be natural flows.

Selected results were compared with recorded near-natural flows from a representative mountain stream and a representative plains stream, and with recorded flows near the mouth of the Milk River. The monthly distribution of synthesized natural flows compared favorably with the distributions from the representative streams. The synthesized annual flows at the mouth compared favorably with the recorded flows near the mouth when the effects of upstream irrigation were considered.

\section{INTRODUCTION}

The Bureau of Reclamation (BOR) is developing a monthly streamflow accounting model to evaluate the effects of various water-allocation schemes on water availability at selected locations in the Milk River Basin in Montana. To make comparisons between schemes, a consistent data set of natural flows (unaffected by human use) is required. Accordingly, the BOR needs natural monthly flows at 13 sites for the base period 1928-89. Of the 13 sites (table 1), hereinafter referred to as nodes, 2 are in the St. Mary River Basin and 11 are in the Milk River Basin (fig. 1). Because six of the nodes are at U.S. Geological Survey (USGS) streamflow-gaging stations and because the USGS has synthesized natural flows for international apportionment purposes at several nodes in the study area, the BOR requested that the USGS synthesize monthly natural flows for use in the model.

This report, which was prepared in cooperation with the BOR, presents the results of the synthesis of natural flows for the 1928-89 base period for 13 nodes. Because the amount of streamflow and water-use data for the nodes varied, several methods were used to synthesize natural flows. The study area includes the St. Mary River Basin in Montana and the Milk River Basin. The Milk River originates along the east side of the St. Mary River Basin boundary in northwest Montana, flows northeast into Alberta, Canada, and then flows eastward for about $110 \mathrm{mi}$ before reentering Montana (fig. 1). The river continues flowing in a southeasterly direction until it joins the Missouri River downstream from Fort Peck Lake near Nashua in northeastern Montana. 


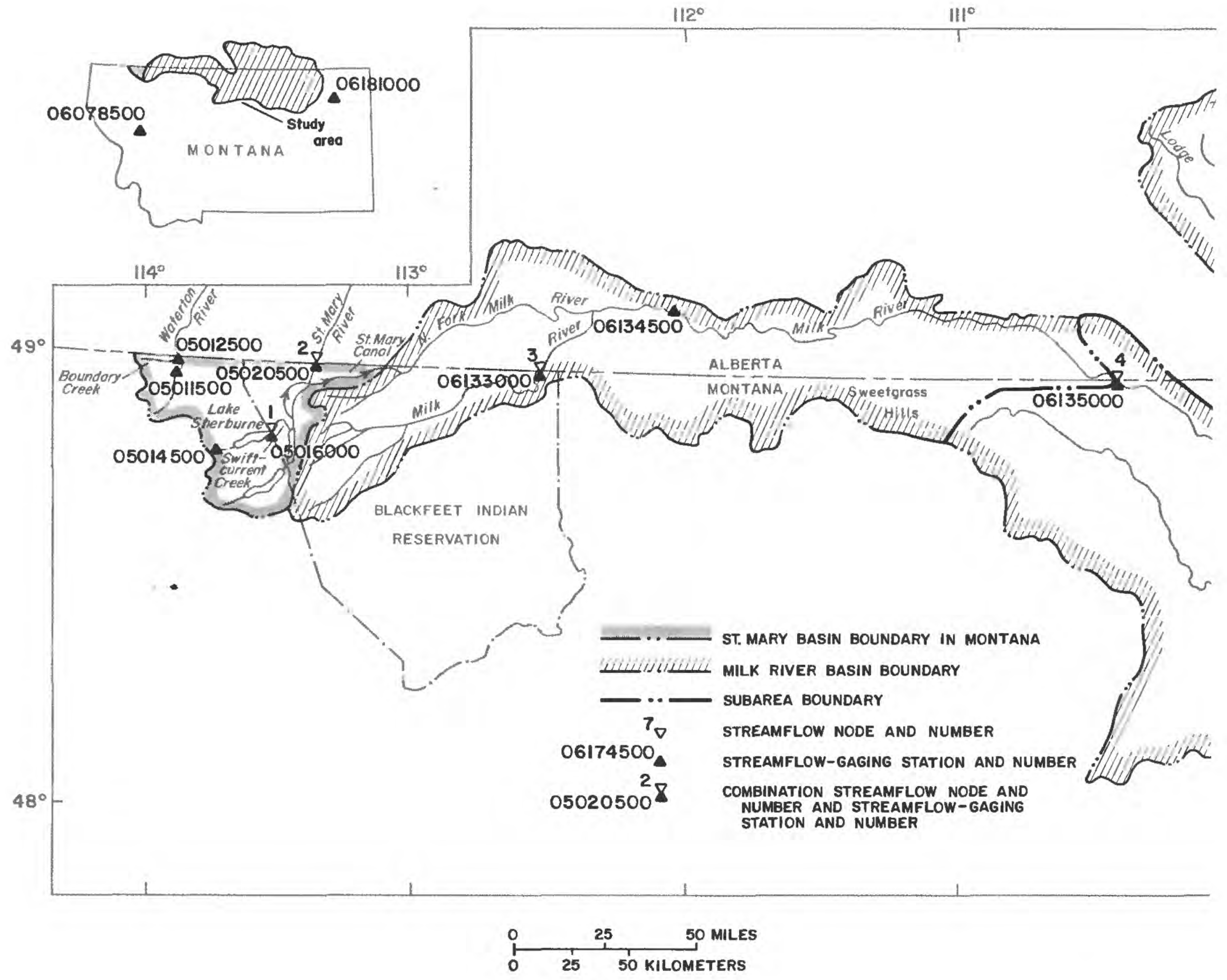

Figure 1. Location of the St. Mary River Basin in Montana and Milk River Basin, streamflow accounting- 


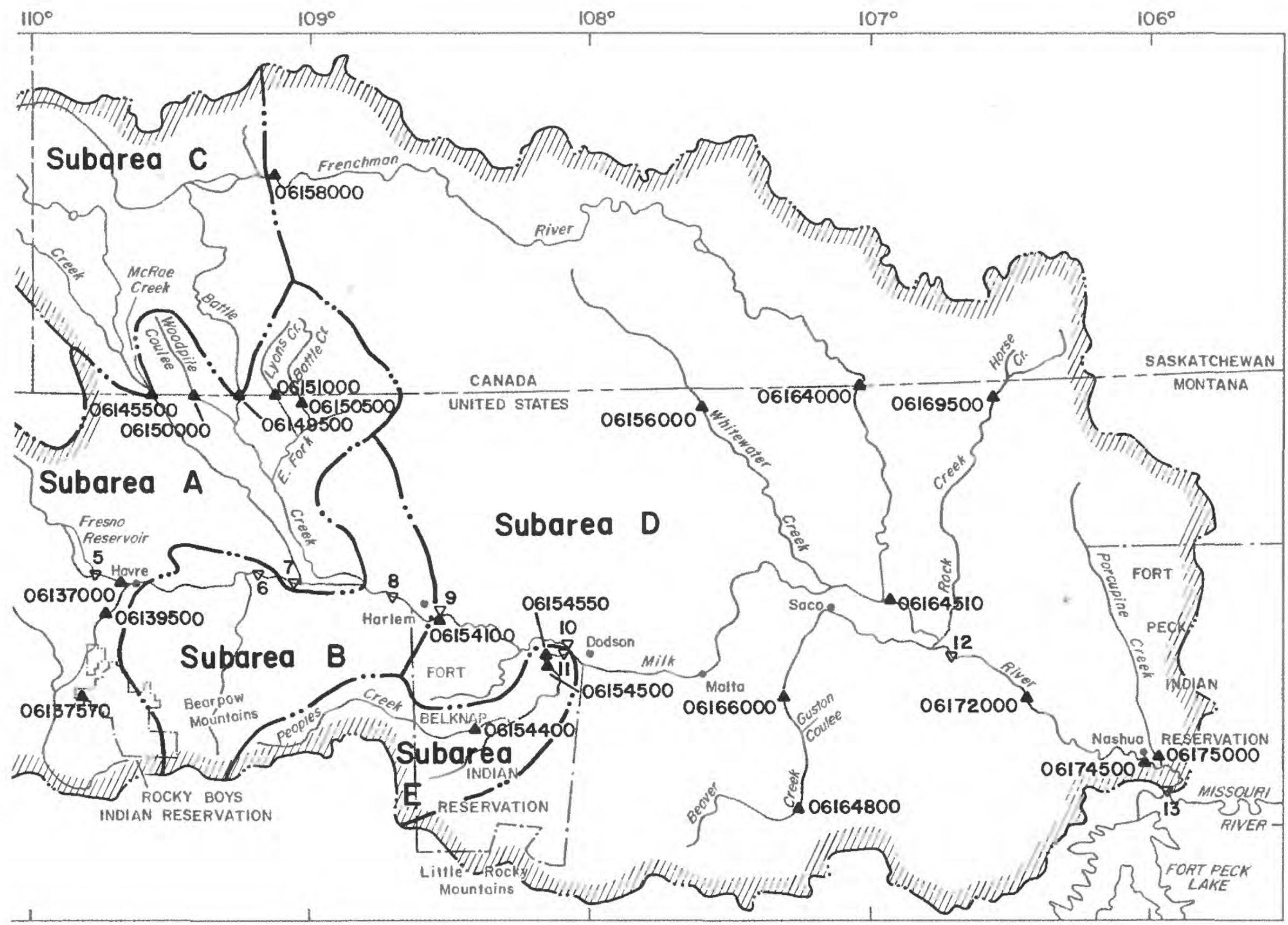

model nodes, and streamflow-gaging stations used in data synthesis and extension of records. 
Table 1. Streamflow accounting-model nodes and associated streamflow-gaging stations in the St. Mary and Milk River Basins, Montana

$[-$, no data $]$

\begin{tabular}{clcc}
\hline $\begin{array}{c}\text { Node } \\
\text { no. }\end{array}$ & \multicolumn{1}{c}{ Node name } & $\begin{array}{c}\text { Gaglng atation } \\
\text { no. }\end{array}$ & $\begin{array}{c}\text { Period of record aince } \\
\text { 1928 }\end{array}$ \\
\hline 1 & Swiftcurrent Creek at Sherburne & 05016000 & $1928-81 ;$ \\
& & & $1984-89^{1}$ \\
2 & St. Mary River at International Boundary & 05020500 & $1928-89$ \\
3 & Milk River at Western Crossing of International Boundary & 06133000 & $1931-89^{1}$ \\
4 & Milk River at Eastern Crossing of International Boundary & 06135000 & $1928-89^{1}$ \\
5 & Milk River below Fresno Reservoir & - & - \\
6 & Milk River at Ft. Belknap diversion dam & - & - \\
7 & Milk River at Paradise diversion dam & - & - \\
8 & Milk River at Harlem pumping plant & - & - \\
9 & Milk River near Harlem & & $1959-69$ \\
& & - & $1983-89$ \\
10 & Milk River upstream from Peoples Creek & $06154500^{3}$ & - \\
11 & Peoples Creek at mouth & - & $1951-73$ \\
12 & Milk River at Vandalia diversion dam & - & $1982-88$ \\
13 & Milk River at mouth & -- \\
\hline
\end{tabular}

${ }^{1}$ Monthly data are available only for March-October.

${ }^{2}$ Station data were not used to synthesize natural flows.

${ }^{3}$ Streamflow-gaging station, Peoples Creek near Dodson, Mont., is located about $7 \mathrm{mi}$ upstream from node.

The Milk River drains about $23,000 \mathrm{mi}^{2}$ in the United States and Canada, including mountains and plains areas. From the headwaters in the mountains to Fresno Reservoir, the tributaries drain plains areas and the Sweetgrass Hills. From Fresno Reservoir to the confluence of Peoples Creek, the tributaries joining from the south drain the Bearpaw and Little Rocky Mountains, whereas tributaries joining from the north drain plains areas. From the confluence of Peoples Creek to the mouth of the river, the tributaries joining from the north and south drain plains areas.

The major use of water in the Milk River Basin in both the United States and Canada is for irrigation. Some of the water used in the basin is from a transbasin diversion from the St. Mary River drainage in Montana. Water from Swiftcurrent Creek, a tributary to the St. Mary River, is stored in Lake Sherburne and released during the irrigation season to supplement flow of the St. Mary River. Water is diverted from the St. Mary River via the St. Mary Canal into the North Fork of the Milk River near the International Boundary.

Water is diverted from the Milk River and its tributaries for irrigation and municipal supply and is stored in reservoirs for future use. The largest reservoir (103,000 acre-ft) is Fresno Reservoir on the mainstem Milk River in Montana. Numerous smaller reservoirs are located on tributaries.

\section{SYNTHESIS OF NATURAL FLOWS}

At five nodes where gaged flow data were available, natural flows for the periods of record had either been previously synthesized by the U.S. Geological Survey and Water Survey of Canada (USGS/WSC) or were considered to be the same as the recorded flows (D.B. Hanson, U.S. Geological Survey, written commun., 1992). For the remaining eight nodes, a method developed by the Montana Reserved Water Rights Compact Commission (MRWRCC) that used flow records from selected (index) gaging stations was used to synthesize natural flows (Robert A. Levitan, Montana Reserved Water Rights Compact Commission, written commun., 1990). Because some gaging stations at nodes and some index gaging stations were operated seasonally and because the gaging stations had variable record lengths, a streamflow record-extension program was used to estimate missing monthly flows within the base period.

Nodes 1 and 2 are in the St. Mary River Basin where water use is negligible. However, Swiftcurrent Creek at Sherburne (node 1) and St. Mary River at International Boundary (node 2) are affected by regulation of Lake Sherburne. In addition, irrigation-season flows at node 2 are affected by diversions into the St. Mary Canal which supplies the Milk River with irrigation water: Monthly natural flows for nodes 1 and 2 were previously synthesized by the USGS/WSC for 
March or April through October for the base period. In addition, total natural flow for each year for the period of record for November through March was previously synthesized for node 2. Total natural flow for November through March of each year was disaggregated into monthly natural flows by multiplying the total by the ratios of recorded monthly flows to recorded total flow.

Nodes 3-13 are in the Milk River Basin. The first node in the Milk River Basin is Milk River at Western Crossing of International Boundary (node 3 ), where upstream water use is negligible and flows are not regulated. Therefore, the seasonal (March through October) flows recorded at the streamflow-gaging station, Milk River at Western Crossing of International Boundary (06133000), were considered to be natural flows for node 3.

For Milk River at Eastern Crossing of International Boundary (node 4), monthly natural flows for the period of record for March through October were previously synthesized by the USGS/WSC. In addition, total flow for each year for the period November through February, which was assumed to be natural, was determined by the USGS. At this node, total flow for November through February for each year in the base period was disaggregated into monthly flows by multiplying total flow by the ratios of monthly flow to total flow for the period November through February determined from an upstream, streamflow-gaging station, Milk River at Milk River, Alberta (06134500), which is operated year-round.

Monthly natural flows for all mainstem nodes from node 5 to node 13 were synthesized using a method developed by the MRWRCC for synthesis of flows at node 9 . The method developed by the MRWRCC was based on synthesizing natural runoff from the intervening drainage area between nodes 4 and 9 , then adding the runoff to previously synthesized natural flows at node 4. The MRWRCC divided the intervening drainage area between nodes 4 and 9 into three subareas $(A, B$, and $C$ ) based on runoff characteristics and historical flow data (fig. 1). Total monthly natural runoff from each subarea was synthesized by using recorded or synthesized monthly flows at one or more index gaging stations and an adjustment factor based on the ratio of total drainage area of the subarea to the combined drainage areas of the index stations. For example, if two index stations with a combined drainage area of $200 \mathrm{mi}^{2}$ were used to synthesize monthly runoff from a subarea with a drainage area of $500 \mathrm{mi}^{2}$, recorded flows for the index stations would be added together and multiplied by $(500 / 200)$ to obtain synthesized natural runoff from the subarea. The index stations used for each subarea, along with the associated drainage areas, are listed in table 2 . The intervening drainage area for each subarea, by node, is listed in table 3.

This method was used for the synthesis of natural flows at Milk River nodes because it eliminated the need to consider mainstem reservoir regulation or diversions. Application of the method to nodes between nodes 4 and 9 required some adjustment because the intervening drainage areas included only portions of subareas A, B, and C. Application of the method to Milk River nodes downstream from node 9 required the delineation of two additional subareas (D and $\mathrm{E})$.

Subarea A comprises generally low-runoff-producing plains where streams commonly flow only intermittently. Index stations within subarea A (table 2) having recorded flows that were considered to be near-natural and generally representative of total runoff from subarea A were Woodpile Coulee near International Boundary (06150000), East Fork Battle Creek near International Boundary (06150500), and Lyons Creek at International Boundary (06151000). In addition, Whitewater Creek near International Boundary $(06156000)$ was selected to be an index station for subarea $\mathrm{A}$, even though it is located in a different subarea, because its runoff characteristics were considered to be similar to those of most streams in subarea $A$. The total drainage area of subarea $A$ is $3,661 \mathrm{mi}^{2}$ (table 3 ). The total drainage area of the four index stations is 674 $\mathrm{mi}^{2}$. Total natural runoff for any month from subarea A was thus the combined flow for that month from the four index stations times $(3,661 / 674)$.

Although subarea $B$ is mostly plains, it includes the Bearpaw Mountains which produce more runoff than do the plains. The single index station (table 2) having flows that were considered to be near-natural and most representative of runoff from subarea $B$ is Peoples Creek near Dodson (06154500) which is located in subarea $E$. The total drainage area of subarea B is $1,628 \mathrm{mi}^{2}$ (table 3 ), and the drainage area of the index station is $670 \mathrm{mi}^{2}$. Total natural runoff for any month from subarea B was thus calculated as the recorded flow for that month at the index station times $(1,628 / 670)$.

Subarea $C$ includes the drainage basins of Lodge Creek below McRae Creek at the International Boundary (06145500) and Battle Creek at the International Boundary (06149500). Although recorded flows at these sites have been affected by upstream use, storage, and diversions, natural flows have previously been synthesized by the Canada Department of Environment (Environment Canada) for the period 1911-69 (Water Planning and Management Branch, 1972) and by the USGS/WSC for the period 1961-89. The total 
Table 2. Index stations and drainage areas for each subarea, Montana and Alberta and Saskatchewan, Canada

\begin{tabular}{|c|c|c|c|}
\hline Subarea & Station number & Statlon name & $\begin{array}{l}\text { Contributing } \\
\text { drainage area, in } \\
\text { square miles }\end{array}$ \\
\hline $\mathbf{A}$ & $\begin{array}{r}06150000 \\
06150500 \\
06151000 \\
06156000^{1}\end{array}$ & $\begin{array}{l}\text { Woodpile Coulee near International Boundary } \\
\text { East Fork Battle Creek near International Boundary } \\
\text { Lyons Creek at International Boundary } \\
\text { Whitewater Creek near International Boundary } \\
\text { Total for index stations representing subarea A (Index A) }\end{array}$ & $\begin{array}{l}60.2 \\
89.5 \\
66.7 \\
\frac{458}{674}\end{array}$ \\
\hline $\mathrm{C}$ & $\begin{array}{l}06145500 \\
06149500\end{array}$ & $\begin{array}{l}\text { Lodge Creek below McRae Creek, at International Boundary } \\
\text { Battle Creek at International Boundary } \\
\text { Total for index stations in subarea C (Index C) }\end{array}$ & $\begin{array}{r}738 \\
\underline{619} \\
1,357\end{array}$ \\
\hline $\mathrm{E}$ & 06154500 & $\begin{array}{l}\text { Peoples Creek near Dodson } \\
\text { Total for index station in subarea E (Index E) }\end{array}$ & $\frac{670}{670}$ \\
\hline
\end{tabular}

\footnotetext{
${ }^{1}$ Station located in subarea D.

${ }^{2}$ Station located in subarea $\mathrm{E}$.
}

Table 3. Intervening drainage areas in Montana and Alberta and Saskatchewan, Canada, from Milk River at Eastern Crossing of International Boundary to mouth of the Milk River, Montana

\begin{tabular}{|c|c|c|c|c|c|c|}
\hline \multirow{2}{*}{$\begin{array}{c}\text { Model } \\
\text { node } \\
\text { no. }\end{array}$} & \multirow[t]{2}{*}{ Model node name } & \multicolumn{5}{|c|}{$\begin{array}{l}\text { Intervening drainage areas within specifled aubareas } \\
\text { (square miles) }\end{array}$} \\
\hline & & A & $\mathbf{B}$ & $\mathbf{C}$ & $\mathrm{D}$ & E \\
\hline 4 & Milk River at Eastern Crossing of International Boundary & 0 & 0 & 0 & 0 & 0 \\
\hline 5 & Milk River below Fresno Reservoir & 960 & 0 & 0 & 0 & 0 \\
\hline 6 & Milk River at Ft. Belknap diversion dam & 2,488 & 502 & 0 & 0 & 0 \\
\hline 7 & Milk River at Paradise diversion dam & 2,646 & 660 & 0 & 0 & 0 \\
\hline 8 & Milk River at Harlem pumping plant & 3,661 & 1,326 & 1,357 & 0 & 0 \\
\hline 9 & Milk River near Harlem & 3,661 & 1,628 & 1,357 & 0 & 0 \\
\hline 10 & Milk River upstream from Peoples Creek & 3,661 & 1,628 & 1,357 & 635 & 0 \\
\hline 12 & Milk River at Vandalia diversion dam & 3,661 & 1,628 & 1,357 & 10,400 & 670 \\
\hline 13 & Milk River at mouth & 3,661 & 1,628 & 1,357 & 12,620 & 670 \\
\hline
\end{tabular}


drainage area of subarea $\mathrm{C}$ is $1,357 \mathrm{mi}^{2}$ and is coincident with the combined drainage areas of the two index stations (tables 2 and 3). Total natural runoff for any month from subarea $C$ is thus the combined synthesized natural flow for that month from the two index stations.

Subarea D consists of the intervening Milk River drainage between node 9 and the mouth, except for the drainage area of Peoples Creek, and comprises generally low-runoff-producing plains. Index stations (table 2) having recorded flows that are considered to be near-natural and generally representative of streams draining subarea $D$ are Beaver Creek below Guston Coulee, near Saco (station 06166000), Rock Creek below Horse Creek, near International Boundary (station 06169500), and Porcupine Creek at Nashua (station 06175000). In addition, Frenchman River at International Boundary (station 06164000), although heavily used and regulated upstream, was used as an index station because the USGS/WSC had previously synthesized natural flows for water apportionment purposes for the period 1937-89.

Subarea E, which is drained only by Peoples Creek, is separate from subarea $D$ because it includes part of the Bearpaw Mountains and because Peoples Creek near Dodson (06154500) is a separate node (node 11) for which synthesized natural flows were required. Peoples Creek is thus used as an index station for both subareas $B$ and $E$.

Natural runoff for any month at a node between node 4 and the mouth was synthesized using the following equation:

$$
\begin{aligned}
\text { Runoff }= & (\text { Area A / Index A) } \times \text { QA } \\
& +(\text { Area B / Index B }) \times Q B \\
& +(\text { Area C / Index C) } \times \text { QC } \\
& +(\text { Area D / Index D) } \times \text { QD } \\
& +(\text { Area E / Index E) } \times \text { QE }
\end{aligned}
$$

where Areas A, B, C, D, and E are the portions of intervening drainage area within subareas $A, B, C, D$, and $\mathrm{E}$, respectively. Index $\mathrm{A}, \mathrm{B}, \mathrm{C}, \mathrm{D}$, and $\mathrm{E}$ are the combined drainage areas of the index stations for subareas $A, B, C, D$, and $E$, respectively. QA, QB, QC, $\mathrm{QD}$, and $\mathrm{QE}$ are the combined flows of the index stations in subareas $A, B, C, D$, and $E$, respectively.

To illustrate the use of equation 1 , assume that the combined flow for some month for the 4 index stations in subarea $\mathrm{A}$ is $30 \mathrm{ft}^{3} / \mathrm{s}$. For the same month, the flow for the index station for subarea $B$ and $E$ is 25 $\mathrm{ft}^{3} / \mathrm{s}$, the combined flow for the 2 index stations for subarea $\mathrm{C}$ is $110 \mathrm{ft}^{3} / \mathrm{s}$, and the combined flow for the 4 index stations for subarea $D$ is $140 \mathrm{ft}^{3} / \mathrm{s}$. To synthesize natural runoff for the area between nodes 4 and 10, the portion of intervening area within each subarea is determined from table 3 as follows:

$$
\begin{aligned}
& \text { Area } A=3,661 \text { square miles } \\
& \text { Area } B=1,628 \text { square miles } \\
& \text { Area } C=1,357 \text { square miles } \\
& \text { Area } D=635 \text { square miles } \\
& \text { Area } E=\quad 0 \text { square miles }
\end{aligned}
$$

Because none of subarea $\mathrm{E}$ is included in the intervening drainage area between nodes 4 and 10 , subarea $E$ is not a part of subsequent calculations.

From table 2, the combined drainage areas of the index stations in subareas $A, B, C$, and $D$ are as follows:

$$
\begin{aligned}
& \text { Index } A=674 \text { square miles } \\
& \text { Index } B=670 \text { square miles } \\
& \text { Index } C=1,357 \text { square miles } \\
& \text { Index } D=4,048 \text { square miles }
\end{aligned}
$$

From equation 1, natural runoff for the intervening drainage area between nodes 4 and 10 for the specified month is computed as follows:

$$
\begin{aligned}
\text { Runoff }= & (3,661 / 674) \times 30.0+(1,628 / 670) \times \\
& 25.0+(1,357 / 1,357) \times 110+ \\
& (635 / 4,048) \times 140 \\
= & (5.43) \times 30.0+(2.43) \times \\
& 25.0+(1.00) \times 110+0.157 \times(140) \\
= & 163+60.8+110+22.0 \\
= & 356 \mathrm{ft}^{3} / \mathrm{s} .
\end{aligned}
$$

\section{STREAMFLOW RECORD EXTENSION}

To extend short-term and seasonal flow records to the 1928-89 base period, a streamflow recordextension program developed by Alley and Burns (1983) was used. This program selects the best nearby (base) station from all those available in a region to estimate, using a regression technique, each month of missing record at a node. Thus, if a node has several months of missing record, several different base stations may be used for estimating missing flows. The criterion for selection is to use the base station that results in the smallest standard error of prediction for that month. Only stations with flow record for a particular month and year were used to estimate missing flows at other nodes for that month and year, previously estimated flows were not used to estimate other missing flows. Flow records were extended to the 1928-89 base period at 3 nodes and 10 index stations used to synthesize natural flow at nodes in the St. Mary and Milk River Basins. 
The regression technique used in the streamflow record-extension program is the MOVE.1 (Maintenance of Variance Extension, Type 1) curve-fitting technique described by Hirsch (1982). This technique is analogous to ordinary least-squares (OLS) regression, but MOVE. 1, unlike OLS regression, results in an extended flow record with a variance comparable to that of the unextended flow record.

To extend flow records at the nodes and index stations, 24 stations were used as base stations in the record-extension program (table 4 at the back of the report). Included in the list of base stations are some nodes for which both recorded and natural-flow data are available. Based on the selection criteria, the recorded flow data were used to estimate missing record at some nodes, and the synthesized natural flows were used to estimate missing record at other nodes.

Because the synthesized natural-flow records for Lodge Creek below McRae Creek at International Boundary (06145500) and Battle Creek at International Boundary (06149500) were computed by two sources, the streamflow record-extension program was used at each node to ensure that natural flows would be consistent for the 1928-89 base period. The MOVE.1 technique was thus used at each node to regress natural flows determined by Environment Canada against natural flows determined by the USGS/WSC in order to extend natural-flow record determined by the USGS/ WSC. For convenience in the use of the streamflow record-extension program, synthesized natural-flow records at streamflow-gaging stations were assigned the same station numbers as the gages except for the last two digits. The last two digits of station numbers for natural-flow records synthesized by Environment Canada were 99, whereas the last two digits of station numbers for natural-flow records synthesized by the USGS/WSC were 88. Thus, for example, the station number assigned to the natural-flow record for Battle Creek that was synthesized by Environment Canada was 06145599, and the station number assigned to the natural-flow record at this station that was synthesized by the USGS/WSC was 06145588.

The results of streamflow synthesis are presented in tables 5-17 at the back of the report. One table was prepared for each node and shows the synthesized total monthly flow volume, in acre-feet, for each calendar year of the base period.

\section{RELIABILITY OF RESULTS}

Owing to man's activities in the Milk River Basin that predate the establishment of streamflow-gaging stations, no data were available to which the results of the synthesis of natural flows could be directly compared. However, some qualitative comparisons could be made based on the seasonal distribution of flows from a typical mountain stream and a typical plains stream that were little affected by irrigation. In addition, a comparison between synthesized and historical flows near the mouth of the Milk River provided insight as to the correctness of the magnitude and distribution of synthesized natural flows.

Reservoir releases and irrigation-return flows weeks or months after the water was diverted or stored result in an alteration in the monthly distribution of flows. However, the monthly distribution of synthesized natural flows should be similar to the monthly distribution of flows from similar streams that are not affected by diversions or storage.

Monthly flow distributions for the North Fork Sun River near Augusta, Mont. (06078500), a station on a mountain stream, and the Poplar River near Poplar, Mont. (06181000), a station on a plains stream, were compared with the monthly distributions of synthesized natural flows for two nodes on the Milk River. Neither comparison station has significant upstream irrigation diversions. A small reservoir provides some control of the flows of a tributary to the Poplar River, but its effect on monthly distribution of flow is believed to be minor.

Dimensionless monthly flows were computed for the two comparison stations and for the natural-flow records for Milk River at Eastern Crossing of International Boundary (node 4) and Milk River at mouth (node 13) by dividing the means of the monthly flows by the mean annual flow. A graphical comparison of the dimensionless monthly flows at the comparison stations to the dimensionless monthly natural flows at the two Milk River nodes is shown in fig. 2. As shown in figure 2A, the Milk River at Eastern Crossing of International Boundary (node 4) has a monthly distribution of flows that is intermediate between the distributions of the North Fork Sun and Poplar Rivers. The distribution was similar to those for both the North Fork Sun River and Poplar River from about August through January. The increase in flow owing to spring runoff for the Milk River at Eastern Crossing is similar to that of the Poplar River. From March through July the distribution is generally intermediate between the two comparison stations. The distribution of synthesized natural flows for Milk River at mouth (node 13) is similar to that of the Poplar River throughout the year, indicating that the synthesized natural flows are typical of natural flows of a plains stream.

Finally, the means of synthesized monthly natural flows for the Milk River at mouth (node 13) were compared to the means of recorded monthly flows for the streamflow-gaging station, Milk River at Nashua (station 06174500) for the period of gaged record 


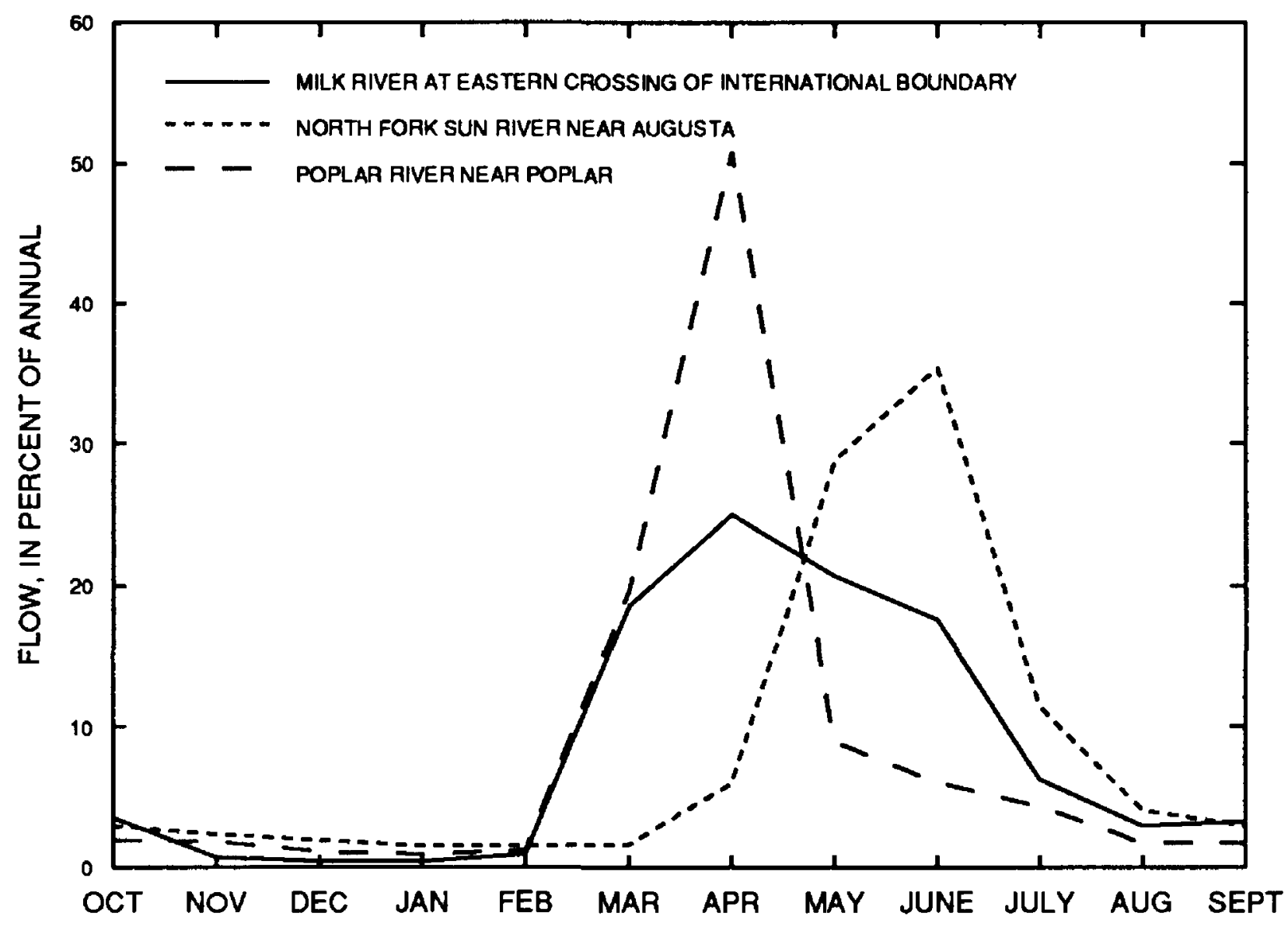

A. Comparison for Milk River at Eastern Crossing of International Boundary (node 4)

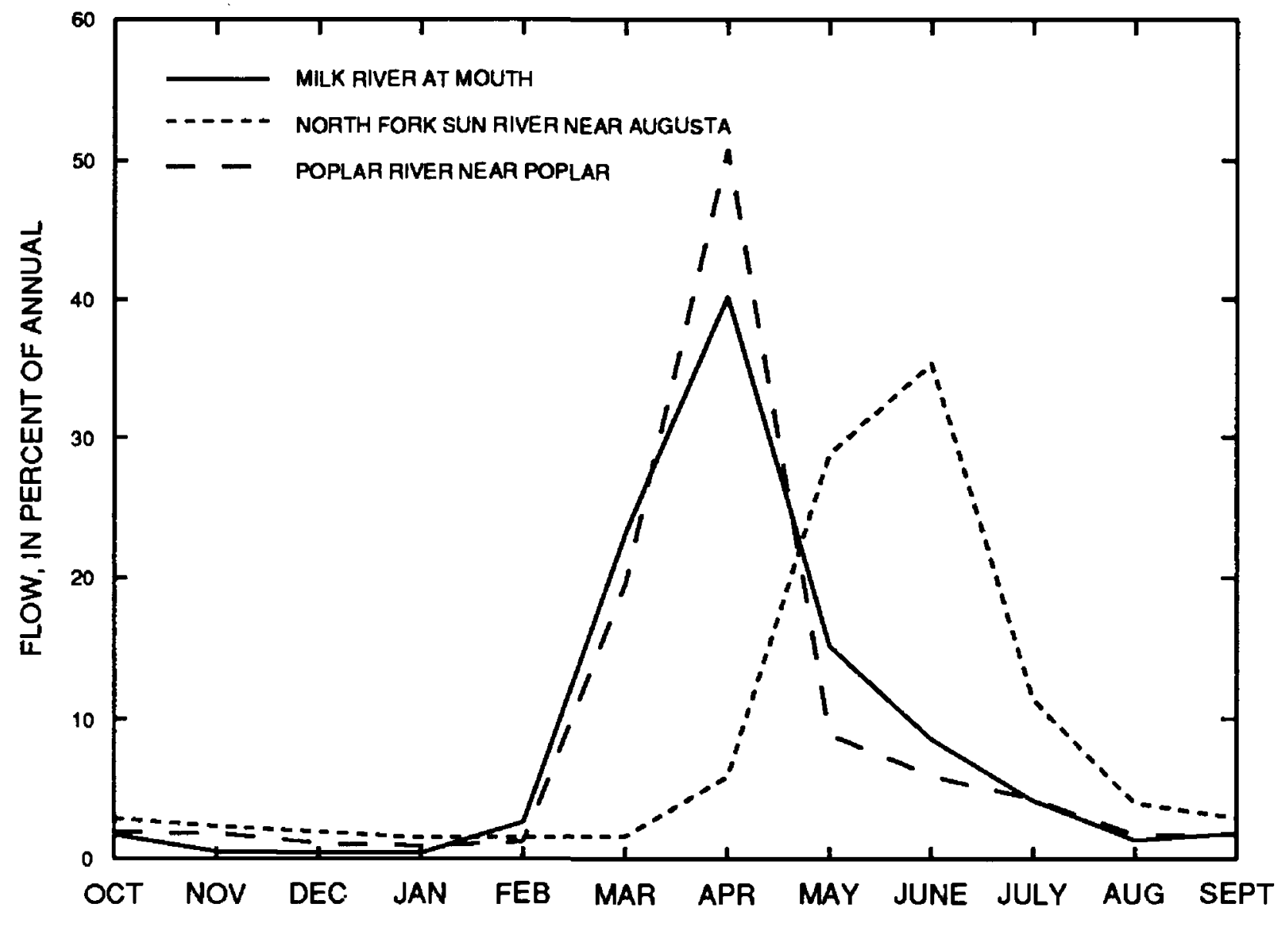

B. Comparison for Milk River at mouth (node 13)

Figure 2. Distribution of dimensionless monthly natural flows for two accounting-model nodes on the Milk River compared to distribution of dimensionless monthly flows for the North Fork Sun River near Augusta, Mont., and Poplar River near Poplar, Mont. 
(1941-90). As shown in figure 3, recorded flows were larger than synthesized flows for October through January, probably as a result of irrigation return flows. Synthesized flows were larger than recorded flows from February through June, probably because of the storage of spring runoff in the numer- ous reservoirs in the basin. From July through September, the hydrographs are nearly the same, indicating that the diversion of water from the St. Mary River Basin and the release of stored water about equaled the water consumptively used by irrigation in the Milk River Basin.

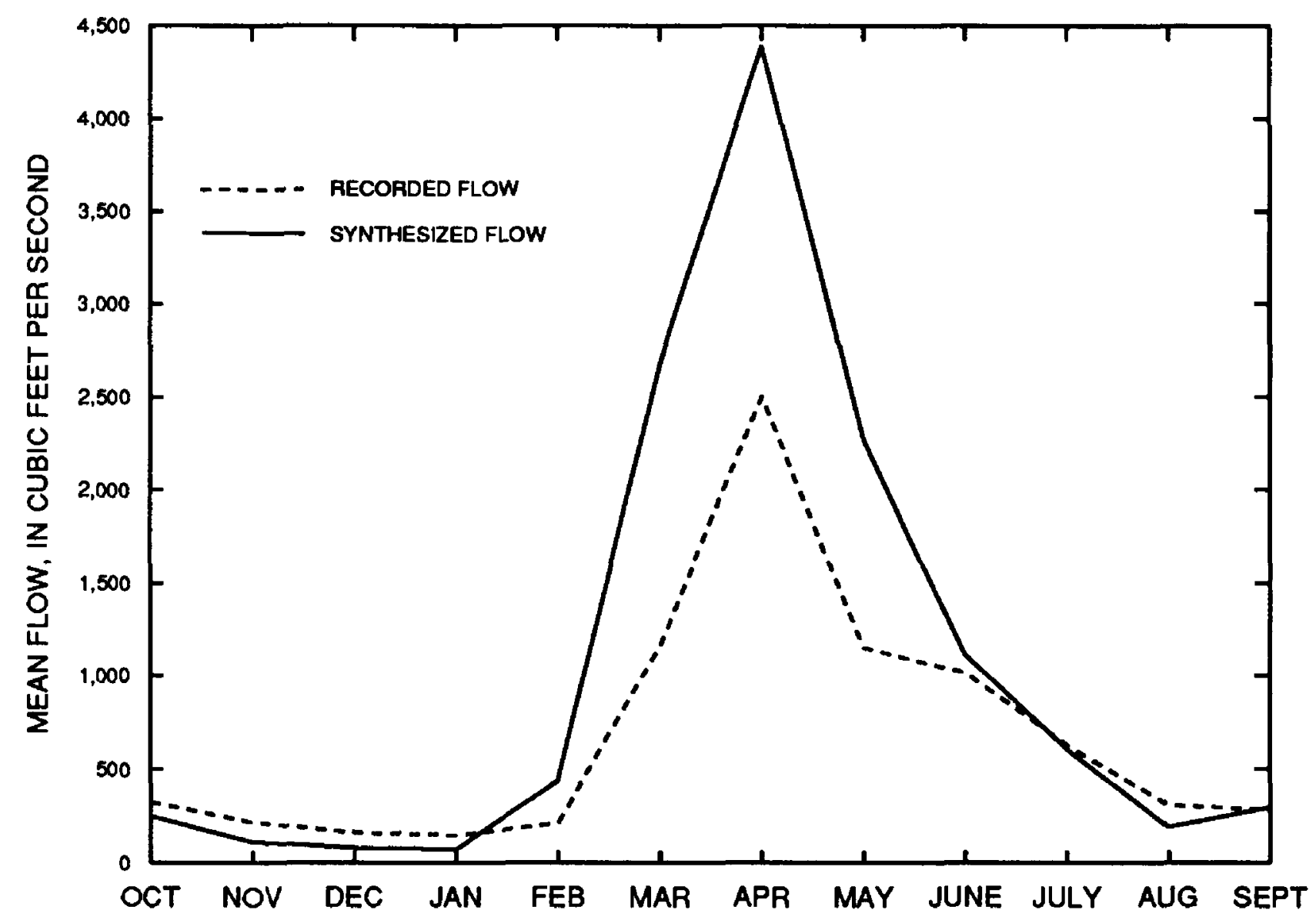

Figure 3. Comparison of means of synthesized monthly natural flows for the Milk River at mouth (accounting-model node 13) with means of recorded monthly flows for Milk River at Nashua (station 06174500). 


\section{SUMMARY}

Natural monthly streamflows were synthesized for 2 sites in the St. Mary River Basin and 11 sites in the Milk River Basin in north-central Montana. The sites are represented as nodes in a streamflow accounting model being developed by the Bureau of Reclamation. The data were synthesized for 1928-89. The methods of synthesis varied depending on the degree of human activities upstream and data availability.

Flows at nodes in the St. Mary River Basin were affected by storage in Lake Sherbume, and flows at the node St. Mary River at International Boundary also were affected by diversion into the St. Mary Canal. Natural flows were previously synthesized by the USGS/WSC for March or April through October. In addition, total flow for November through March had been synthesized for the St. Mary River at International Boundary. The total flow was disaggregated into monthly flows by multiplying the total by the ratios of recorded monthly flows to recorded total flow.

The recorded flows of the Milk River at Westem Crossing of Intemational Boundary were assumed to be the natural flows. Water use and flow regulation upstream from the seasonal streamflow-gaging station were considered to be negligible.

Natural flows for the Milk River at Eastern Crossing of Intemational Boundary were previously synthesized by the USGS. Total flows for November through February were disaggregated to monthly mean flows using percentages computed from recorded winter flows for Milk River at Milk River, Alberta.

The flows at the main-stem nodes downstream from Eastem Crossing were synthesized by adding the synthesized runoff from subareas to natural flows for Milk River at Eastem Crossing. Natural runoff was synthesized by adding the flows from index stations and multiplying by a drainage-area ratio. Flows for Peoples Creek, a tributary to the Milk River, were assumed to be natural flows.
A streamflow record-extension program was used to extend short-term and seasonal flow records to the 1928-89 base period. Flow records were extended at 3 nodes and 10 index stations in the St. Mary and Milk River Basins.

Although the results could not be verified independently, two comparisons were made to check the validity of the results. Dimensionless monthly flows at two nodes, Milk River at Eastem Crossing of International Boundary and Milk River at mouth, were compared with dimensionless monthly flows from a mountain stream (North Fork Sun River) and a plains stream (Poplar River) that were little affected by human use. The monthly distribution of natural flows for Milk River at Eastem Crossing of International Boundary was intermediate between distributions of flow for the mountain and plains streams. The monthly distribution of natural flows for Milk River at mouth resembled that of a plains stream. Synthesized monthly natural flows at the mouth were also compared to recorded flows at Nashua. Synthesized flows were smaller than recorded flows for October through January and were larger than recorded flows for February through June. Synthesized and recorded flows were about the same for July through September. Differences are probably attributable to storage and irrigation effects.

\section{REFERENCES CITED}

Alley, W.M., and Burns, A.W., 1983, Mixed-station extension of monthly streamflow records: American Society of Civil Engineers, Journal of Hydraulic Engineering, v. 109, no. 10, p. 1,272-1,284.

Hirsch, R.M., 1982, A comparison of four streamflow record extension techniques: Water Resources Research, $v$. 18 , no. 4 , p. $1,081-1,088$.

Water Planning and Management Branch, 1972, Water use and water supply studies of Battle and Lodge Creek basins: Canada Department of the Environment, v. 1 and 2, $223 \mathrm{p}$. 


\section{Supplemental Data}


Table 4. Streamflow-gaging stations used in extension of monthly streamflow records at accounting-model nodes and index stations in the St. Mary and Milk River Basins

\begin{tabular}{|c|c|c|c|}
\hline \multicolumn{2}{|r|}{ Statlon whose record was extended } & \multicolumn{2}{|r|}{ Stations used in extenslon } \\
\hline No. & Name & No. & Name \\
\hline 05016000 & Swiftcurrent Creek at Sherburne & $\begin{array}{l}05011500 \\
05012500 \\
05014500 \\
05020500\end{array}$ & $\begin{array}{l}\text { Waterton River near International } \\
\text { Boundary } \\
\text { Boundary Creek at International Boundary } \\
\text { Swiftcurrent Creek at Many Glacier } \\
\text { St. Mary River at International Boundary }\end{array}$ \\
\hline 06133000 & $\begin{array}{l}\text { Milk River at Western Crossing of } \\
\text { International Boundary }\end{array}$ & $\begin{array}{l}05020500 \\
06133500 \\
06134500 \\
06174500\end{array}$ & $\begin{array}{l}\text { St. Mary River at International Boundary } \\
\text { North Fork Milk River above St. Mary } \\
\text { Canal, near Browning } \\
\text { Milk River at Milk River, Alberta } \\
\text { Milk River at Nashua }\end{array}$ \\
\hline 06145588 & $\begin{array}{l}\text { Lodge Creek below McRae Creek, at } \\
\text { International Boundary, natural } \\
\text { flows (USGS) }\end{array}$ & $\begin{array}{l}06145599 \\
06149599 \\
06150000 \\
06154100 \\
06156000 \\
06169500 \\
06174500\end{array}$ & $\begin{array}{l}\text { Lodge Creek below McRae Creek, at } \\
\text { International Boundary, natural } \\
\text { flows (Environment Canada) } \\
\text { Battle Creek at International Boundary, } \\
\text { natural flows (Environment Canada) } \\
\text { Woodpile Coulee near International } \\
\text { Boundary } \\
\text { Milk River near Harlem } \\
\text { Whitewater Creek near International } \\
\text { Boundary } \\
\text { Rock Creek below Horse Creek, near } \\
\text { International Boundary } \\
\text { Milk River at Nashua }\end{array}$ \\
\hline 06149588 & $\begin{array}{l}\text { Battle Creek at International } \\
\text { Boundary, natural flows (USGS) }\end{array}$ & $\begin{array}{l}06149599 \\
06169500\end{array}$ & $\begin{array}{l}\text { Lodge Creek below McRae Creek, at } \\
\text { International Boundary, natural flows } \\
\text { (USGS/WSC) } \\
\text { Battle Creek at International Boundary, } \\
\text { natural flows (Environment Canada) } \\
\text { Rock Creek below Horse Creek, near } \\
\text { International Boundary }\end{array}$ \\
\hline 06150000 & $\begin{array}{l}\text { Woodpile Coulee near International } \\
\text { Boundary }\end{array}$ & $\begin{array}{l}06151000 \\
06154100 \\
06164088 \\
06169500\end{array}$ & $\begin{array}{l}\text { Lodge Creek below McRae Creek, at } \\
\text { International Boundary, natural flows } \\
\text { (USGS/WSC) } \\
\text { Lyons Creek at International Boundary } \\
\text { Milk River near Harlem } \\
\text { Frenchman River at International } \\
\text { Boundary, natural flows (USGS/WSC) } \\
\text { Rock Creek below Horse Creek, near } \\
\text { International Boundary }\end{array}$ \\
\hline
\end{tabular}


Table 4. Streamflow-gaging stations used in extension of monthly streamflow records at accounting-model nodes and index stations in the St. Mary and Milk River Basins (Continued)

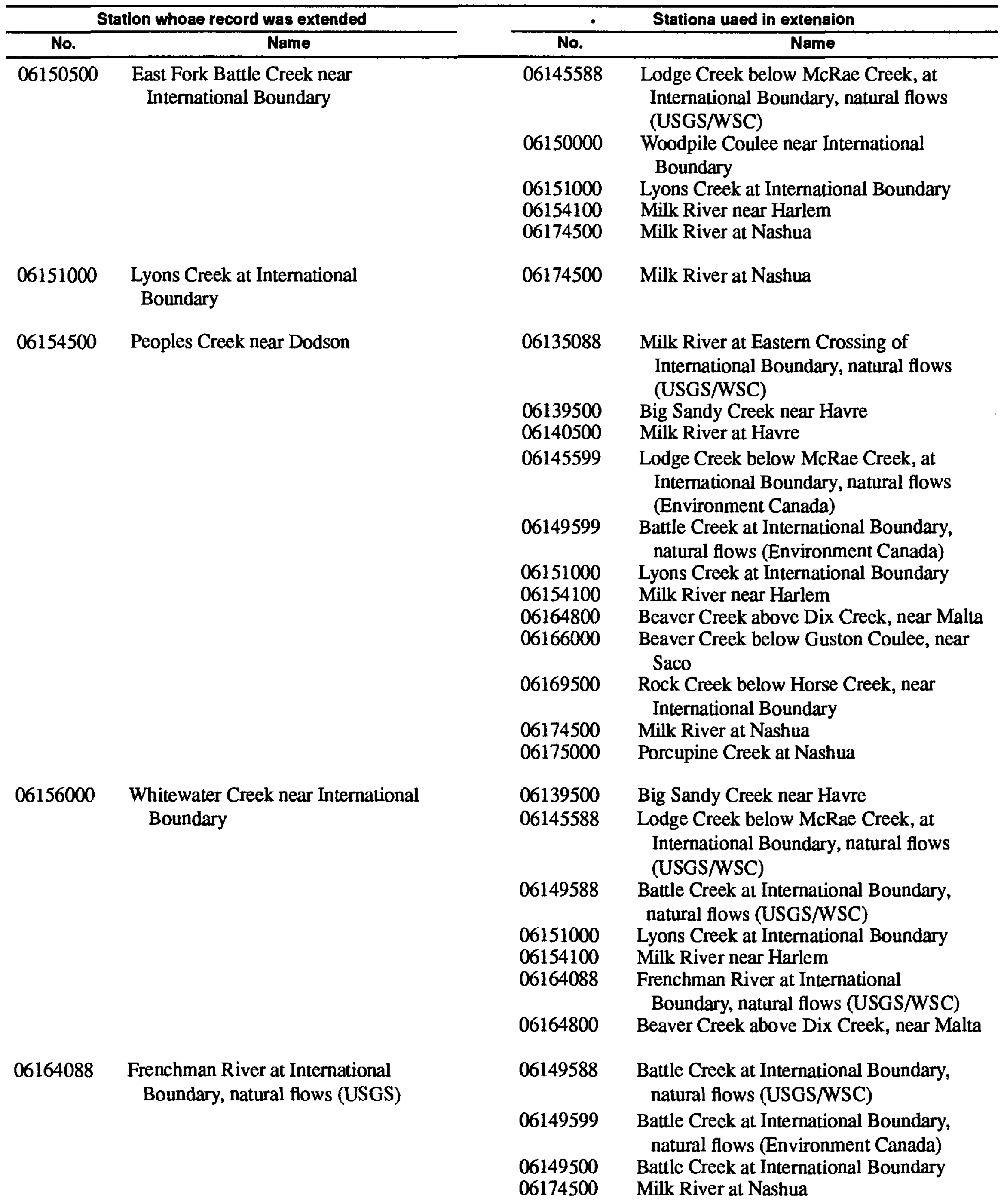


Table 4. Streamflow-gaging stations used in extension of monthly streamflow records at accounting-model nodes and index stations in the St. Mary and Milk River Basins (Continued)

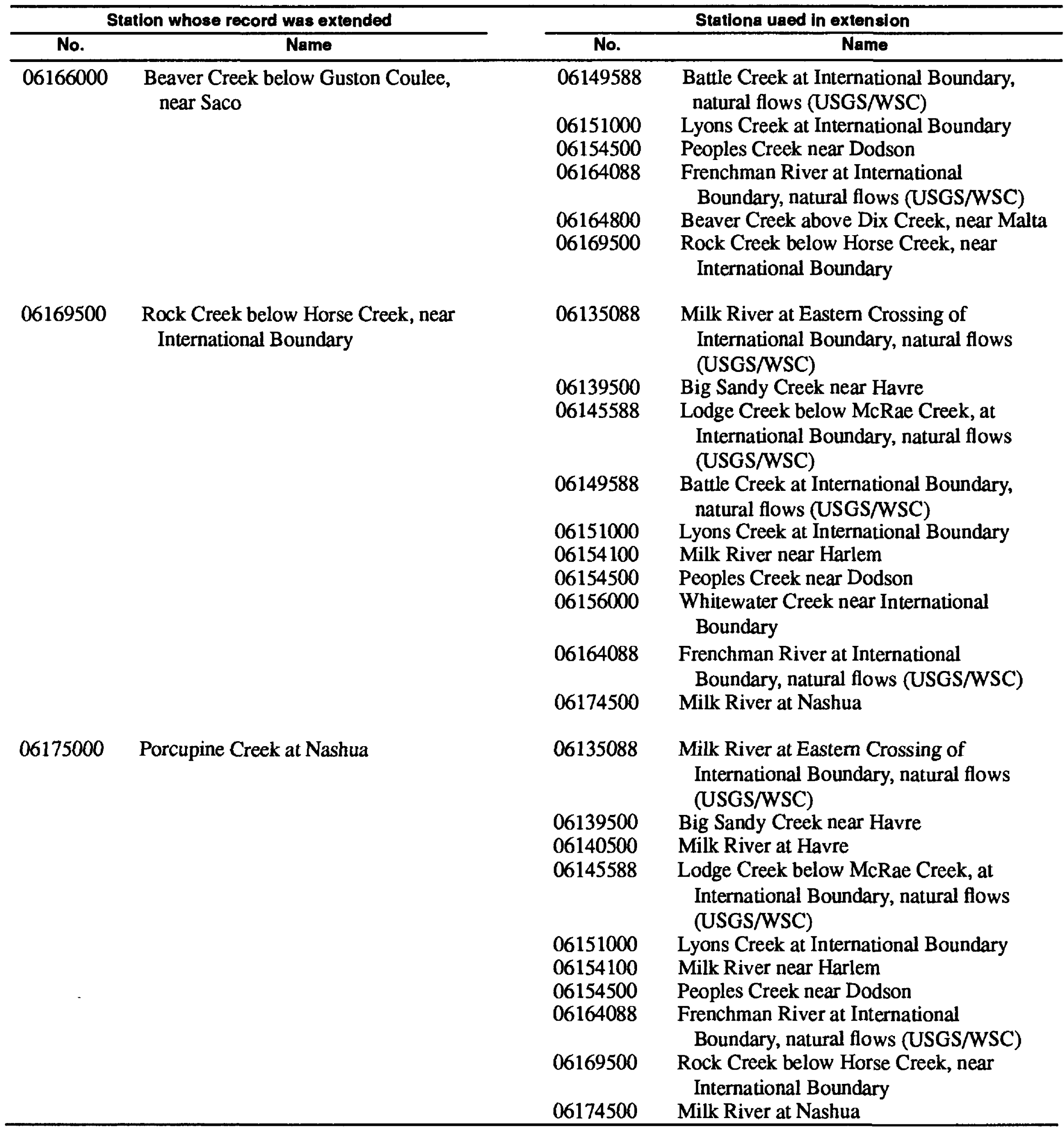


Table 5. Synthesized streamflow volumes for Swiftcurrent Cre日k at Sherburne, Montana, 1928-89, in acre-feet

\begin{tabular}{|c|c|c|c|c|c|c|c|c|c|c|c|c|c|}
\hline YEAR & JAN. & FEB. & MAR. & APR. & MAY & JUNE & JULY & AUG. & SEPT. & OCT. & NOV. & DEC. & TOTAL \\
\hline 1928 & 5,300 & 2,970 & 8,020 & 10,400 & 59,500 & 38,400 & 31,700 & 11,500 & 4,640 & 15,100 & 8,240 & 4,170 & 200,000 \\
\hline 1929 & 2,160 & 1,760 & 3,600 & 5,360 & 34,200 & 30,900 & 17,600 & 8,420 & 3,630 & 4,180 & 2,530 & 1,520 & 116,000 \\
\hline 1930 & 1,630 & 3,640 & 4.790 & 25,000 & 30,700 & 34,200 & 17.700 & 8,920 & 4,280 & 4,860 & 3,110 & 1,810 & 141,000 \\
\hline 1931 & 1,070 & 2,020 & 2,100 & 2,900 & 34,000 & 26,100 & 13,600 & 9,900 & 6,310 & 7,930 & 3,750 & 3,520 & 113,000 \\
\hline 1932 & 1,870 & 3,790 & 8,130 & 7,630 & 38,900 & 37,100 & 18,000 & 10,200 & 4,400 & 9,220 & 4,790 & 4,090 & 148,000 \\
\hline 1933 & 3,410 & 1,490 & 1,850 & 6,860 & 50,600 & 61,900 & 27,400 & 12,900 & 9,100 & 17,600 & 17,900 & 8,650 & 220,000 \\
\hline 1934 & 10,700 & 7,120 & 7,800 & 32,000 & 52,900 & 34,600 & 17,200 & 8,980 & 3,450 & 5,170 & 14,700 & 5,340 & 200,000 \\
\hline 1935 & 5,260 & 6,800 & 5,670 & 7,780 & 29,800 & 35,800 & 22,900 & 11,200 & 6,310 & 4,430 & 1,590 & 1,340 & 139,000 \\
\hline 1936 & 1,560 & 667 & 2,390 & 8,200 & 31,500 & 31,100 & 14,100 & 6,330 & 2,680 & 2,460 & 1.420 & 2,280 & 105,000 \\
\hline 1937 & 2,000 & 1,710 & 2,080 & 3,450 & 31,700 & 25,100 & 42,800 & 8,300 & 4,340 & 5,350 & 7,020 & 2,910 & 137,000 \\
\hline 1938 & 2,280 & 2,100 & 2,670 & 15,700 & 42,200 & 40,200 & 18,600 & 8,050 & 5,650 & 5,600 & 4,280 & 3,080 & 150,000 \\
\hline 1939 & 2,560 & 1,830 & 4,990 & 7,400 & 36,700 & 22,500 & 16,500 & 7,750 & 4,820 & 3,200 & 1,410 & 2,140 & 112,000 \\
\hline 1940 & 1,990 & 1,330 & 2,100 & 9,810 & 51,000 & 23,200 & 10,700 & 4,920 & 8,090 & 5,780 & 2,550 & 2,470 & 124,000 \\
\hline 1941 & 1.950 & 1.280 & 2,240 & 9,400 & 22,600 & 20,000 & 12,200 & 5,040 & 12,000 & 10,500 & 5,030 & 8.970 & 111,000 \\
\hline 1942 & 3,660 & 2,170 & 2,120 & 13,600 & 27,900 & 36,800 & 23,200 & 9,590 & 7,740 & 3.940 & 4,860 & 3,820 & 139,000 \\
\hline 1943 & 2,280 & 2,240 & 1,520 & 19,600 & 30,300 & 4,600 & 31,500 & 9,280 & 4,760 & 5,040 & 2,800 & 1,800 & 158,000 \\
\hline 1944 & 972 & 1,290 & 1,430 & 6,900 & 23,400 & 20,000 & 9.410 & 7,990 & 6,780 & 5,230 & 3,320 & 2,100 & 88,800 \\
\hline 1945 & 1,670 & 1,500 & 1,810 & 3,510 & 38,600 & 42,300 & 18,800 & 6,090 & 8,090 & 6,520 & 10,100 & 3,230 & 142,000 \\
\hline 1946 & 2,500 & 1,840 & 3,110 & 16,200 & 40,500 & 37.400 & 20,800 & 8,180 & 6,840 & 8,420 & 6,650 & 3,620 & 156,000 \\
\hline 1947 & 3,270 & 3,390 & 5,610 & 12,600 & 40,400 & 35,100 & 21,200 & 9,900 & 8,450 & 20,500 & 9,880 & 5,900 & 176,000 \\
\hline 1948 & 4,970 & 2,070 & 1,820 & 8,680 & 43,200 & 54,800 & 16,900 & 9,590 & 4,170 & 3,320 & 2,930 & 2,770 & 155,000 \\
\hline 1949 & 2,510 & 2,190 & 2,700 & 9,820 & 37,400 & 27,000 & 13,100 & 7,320 & 9,460 & 5,530 & 10,100 & 9,110 & 136,000 \\
\hline 1950 & 3,850 & 3,450 & 3,950 & 5,240 & 33,600 & 61,900 & 38,600 & 14,200 & 6,190 & 20,100 & 12,900 & 9,250 & 213,000 \\
\hline 1951 & 5,740 & 6,310 & 3,810 & 12,500 & 43,200 & 38,700 & 35,000 & 12,600 & 17,000 & 18,000 & 5,530 & 3,940 & 202,000 \\
\hline 1952 & 2,570 & 2,620 & 1,960 & 16,700 & 32,000 & 29,900 & 18,600 & 11,400 & 6,010 & 2,890 & 2,340 & 2,320 & 129,000 \\
\hline 1953 & 6,150 & 4,680 & 3,320 & 10,400 & 37,500 & 59,500 & 31,700 & 12,200 & 6,720 & 4,060 & 6,770 & 4,830 & 188,000 \\
\hline 1954 & 3,140 & 3,120 & 3,010 & 5,590 & 46,500 & 47,400 & 41,900 & 17,000 & 11,300 & 12,700 & 9,680 & 6,200 & 208,000 \\
\hline 1955 & 4,260 & 2,650 & 2,690 & 3,580 & 20,600 & 49,000 & 28,900 & 11,100 & 5,530 & 15,200 & 9,500 & 5,510 & 159,000 \\
\hline 1956 & 4,190 & 2,590 & 3,190 & 8,270 & 44,100 & 43,600 & 24,700 & 11,000 & 6,720 & 9,840 & 5,470 & 4,780 & 127,000 \\
\hline 1957 & 3,070 & 2,750 & 3,700 & 6,010 & 51,100 & 36,000 & 14,300 & 7,130 & 4,170 & 5,530 & 4,860 & 2,740 & 141,000 \\
\hline 1958 & 1,360 & 1,790 & 2,450 & 6,660 & 44,800 & 33,000 & 14,300 & 8.490 & 8,750 & 7,990 & 6,910 & 5,220 & 142,000 \\
\hline 1959 & 6,040 & 2,950 & 2,150 & 12,300 & 31,200 & 53,800 & 26,900 & 11,300 & 19,800 & 16,700 & 8,290 & 6,030 & 197,000 \\
\hline 1960 & 1,700 & 1,690 & 3,270 & 10,600 & 25,100 & 43,400 & 20,800 & 9,720 & 6,660 & 4,060 & 4,930 & 4,240 & 136,000 \\
\hline 1961 & 3,730 & 3,270 & 3,070 & 8,090 & 40,200 & 48,100 & 17,300 & 8,790 & 5,240 & 11,800 & 5,770 & 4,320 & 160,000 \\
\hline 1962 & 3,040 & 2,300 & 1,780 & 15,500 & 28,700 & 31,900 & 15,300 & 9,780 & 6,430 & 9,900 & 8,820 & 8,140 & 142,000 \\
\hline 1963 & 2,530 & 5,130 & 3,140 & 8,390 & 26,900 & 46,800 & 24,900 & 7,130 & 4,760 & 5,350 & 4,630 & 3,610 & 143,000 \\
\hline 1964 & 2,100 & 1,530 & 1,330 & 2,920 & 31,100 & 74,400 & 23,500 & 7,810 & 9,340 & 12,300 & 4,780 & 2,830 & 174,000 \\
\hline 1965 & 2,310 & 2,380 & 2,210 & 10,000 & 32,400 & 51,400 & 24,800 & 11,500 & 7,140 & 8,730 & 4,340 & 3,260 & 161,000 \\
\hline 1966 & 2,540 & 1,560 & 2,710 & 10,800 & 34,500 & 40,800 & 22,500 & 8,790 & 4,400 & 6,330 & 5,070 & 3,780 & 144,000 \\
\hline 1967 & 2,570 & 2,790 & 1,600 & 3,210 & 39,500 & 52,000 & 29,200 & 9.900 & 2,680 & 5,780 & 8,530 & 3,170 & 16,1000 \\
\hline 1968 & 4,080 & 3,380 & 5,530 & 6,660 & 30,100 & 43,000 & 21,900 & 11,800 & 17,900 & 9,720 & 6,810 & 3,180 & 164,000 \\
\hline 1969 & 2,670 & 1,550 & 1,480 & 13,800 & 31,500 & 40,500 & 21,200 & 7,750 & 2,800 & 8,610 & 4,860 & 2,450 & 139,000 \\
\hline 1970 & 2,040 & 1,730 & 1,540 & 2,260 & 39,700 & 60,700 & 15,500 & 9,040 & 5,000 & 4,060 & 2,880 & 2,610 & 147,000 \\
\hline
\end{tabular}


Table 5. Synthesized streamflow volumes for Swiftcurrent Creek at Sherburne, Montana, 1928-89, in acre-feet (Continued)

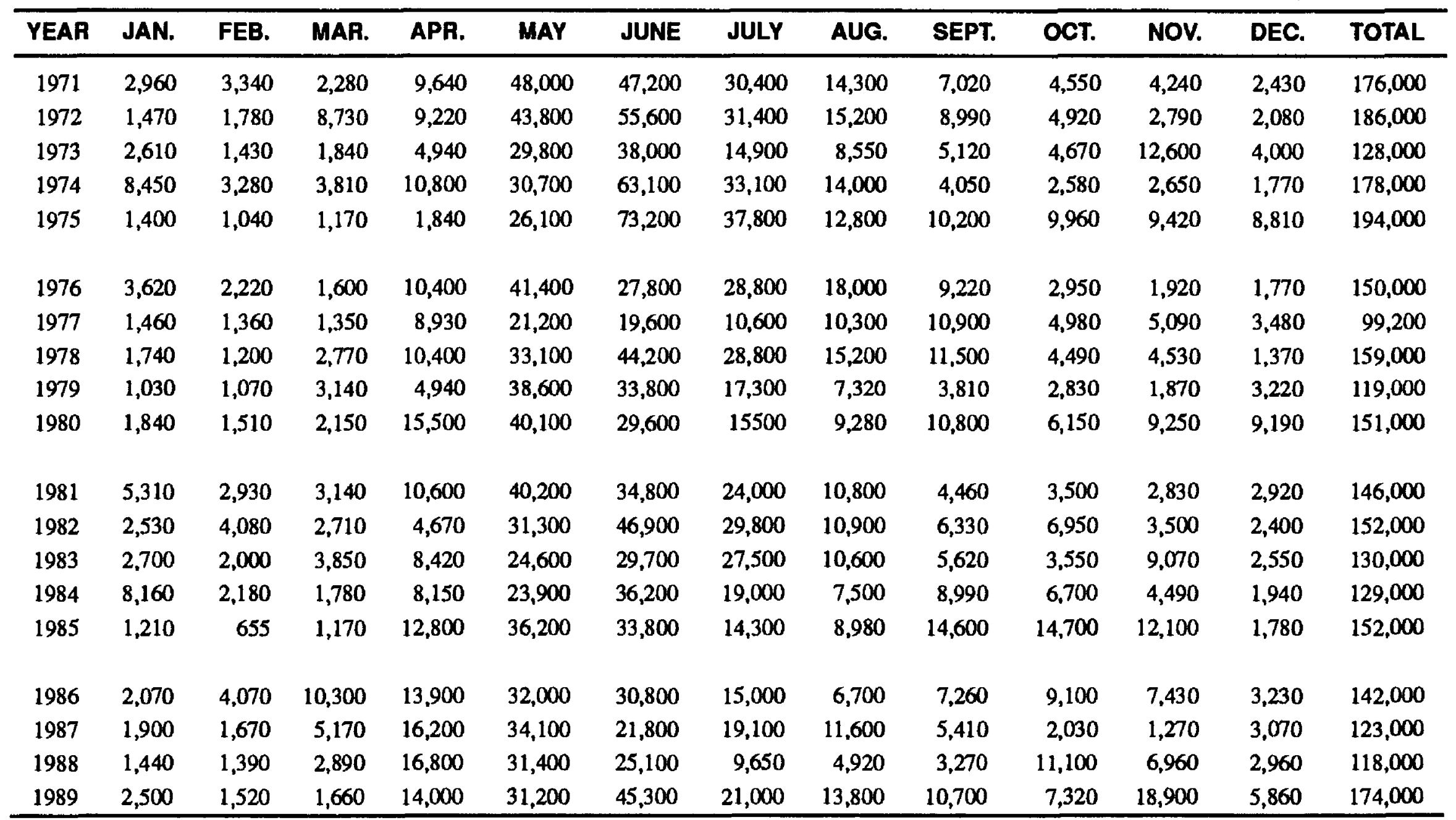


Table 6. Synthesized streamflow volumes for St. Mary River at International Boundary, 1928-1989, in acre-feet

\begin{tabular}{|c|c|c|c|c|c|c|c|c|c|c|c|c|c|}
\hline YEAR & JAN. & FEB. & MAR. & APR. & MAY & JUNE & JULY & AUG. & SEPT. & OCT. & NOV. & DEC. & TOTAL \\
\hline 1928 & 20,000 & 10,300 & 25,300 & 32,500 & 227,000 & 175,000 & 160,000 & 56,600 & 30,500 & 53,100 & 26,100 & 12,600 & 829,000 \\
\hline 1929 & 7,750 & 7,220 & 12,400 & 18,700 & 113,000 & 152,000 & 78,200 & 30,300 & 17,300 & 17,800 & 8,210 & 7,010 & 470,000 \\
\hline 1930 & 7,380 & 14,100 & 15,700 & 87,900 & 149,000 & 148,000 & 77,700 & 31,400 & 22,000 & 19,300 & 12,100 & 5,960 & 591,000 \\
\hline 1931 & 4,610 & 7,940 & 8,180 & 13,300 & 120,000 & 109,000 & 48,900 & 36,400 & 27,600 & 18,100 & 16,200 & 13,900 & 425,000 \\
\hline 1932 & 8,050 & 15,700 & 29,800 & 33,700 & 154,000 & 172,000 & 86,600 & 36,600 & 18,300 & 14,800 & 20,300 & 16,900 & 607,000 \\
\hline 1933 & 14,400 & 7,610 & 8,360 & 24,800 & 108,000 & 258,000 & 133,000 & 47,100 & 29,300 & 42,100 & 57,400 & 27,400 & 758,000 \\
\hline 1934 & 33,800 & 25,000 & 24,700 & 103,000 & 212,000 & 174,000 & 71,000 & 33,200 & 19,200 & 16,500 & 63,600 & 19,100 & 795,000 \\
\hline 1935 & 17,200 & 22,800 & 13,800 & 23,300 & 113,000 & 162,000 & 93,200 & 38,700 & 23,000 & 14,400 & 6,430 & 6,090 & 534,000 \\
\hline 1936 & 5,900 & 3,050 & 8,490 & 36,700 & 149,000 & 128,000 & 50,600 & 25,800 & 15,000 & 9,960 & 5,240 & 7,870 & 445,000 \\
\hline 1937 & 6,640 & 7,160 & 7,070 & 15,900 & 110,000 & 223,000 & 86,600 & 29,200 & 17,700 & 17,500 & 21,200 & 13,100 & 556,000 \\
\hline 1938 & 11,600 & 9,270 & 10,100 & 41,400 & 161,000 & 198,000 & 99,700 & 31,400 & 21,400 & 19,800 & 17,200 & 9,840 & 630,000 \\
\hline 1939 & 8,050 & 7,550 & 16,700 & 38,100 & 140,000 & 102,000 & 65,700 & 28,200 & 17,400 & 11,600 & 8,570 & 8,980 & 453,000 \\
\hline 1940 & 6,760 & 5,000 & 8,550 & 22,700 & 114,000 & 107,000 & 45,300 & 23,500 & 25,400 & 25,500 & 8,930 & 7,990 & 401,000 \\
\hline 1941 & 6,210 & 4,500 & 5,170 & 21,700 & 82,000 & 85,000 & 54,000 & 22,100 & 30,900 & 39,000 & 22,100 & 39,800 & 413,000 \\
\hline 1942 & 14,300 & 9,550 & 8,550 & 40,200 & 116,000 & 165,000 & 112,000 & 46,400 & 31,300 & 24,400 & 19,100 & 16,000 & 603,000 \\
\hline 1943 & 9,470 & 9,830 & 8,920 & 73,800 & 123,000 & 221,000 & 165,000 & 49,800 & 22,400 & 20,200 & 12,100 & 7,930 & 724,000 \\
\hline 1944 & 4,610 & 5,060 & 6,580 & 11,700 & 78,300 & 97,200 & 49,700 & 33,000 & 25,200 & 23,000 & 14,400 & 9,720 & 359,000 \\
\hline 1945 & 7,260 & 7,500 & 7,500 & 9,100 & 123,000 & 201,000 & 89,500 & 28,100 & 28,900 & 25,900 & 32,500 & 13,200 & 574,000 \\
\hline 1946 & 9,530 & 8,780 & 12,800 & 39,200 & 145,000 & 163,000 & 92,200 & 35,100 & 29,500 & 32,000 & 27,500 & 14,700 & 609,000 \\
\hline 1947 & 13,100 & 14,900 & 16,700 & 54,300 & 168,000 & 154,000 & 100,000 & 40,400 & 31,300 & 76,900 & 29,100 & 16,500 & 715,000 \\
\hline 1948 & 9,590 & 7,360 & 8,790 & 37,000 & 182,000 & 326,000 & 96,900 & 46,600 & 19,600 & 16,400 & 8,330 & 5,720 & 765,000 \\
\hline 1949 & 5,170 & 7,050 & 9,160 & 31,300 & 144,000 & 135,000 & 60,900 & 29,000 & 31,700 & 24,800 & 29,800 & 28,300 & 536,000 \\
\hline 1950 & 13,800 & 11,200 & 13,100 & 27,500 & 121,000 & 270,000 & 194,000 & 67,600 & 29,300 & 57,100 & 48,600 & 33,000 & 887,000 \\
\hline 1951 & 21,300 & 20,200 & 18,200 & 48,700 & 207,000 & 204,000 & 199,000 & 69,400 & 71,900 & 85,500 & 31,800 & 16,900 & 994,000 \\
\hline 1952 & 11,400 & 10,600 & 12,200 & 57,700 & 148,000 & 131,000 & 88,100 & 51,600 & 24,300 & 16,200 & 8,030 & 5,660 & 565,000 \\
\hline 1953 & 15,700 & 18,400 & 14,800 & 37,800 & 167,000 & 329,000 & 155,000 & 54,500 & 26,100 & 17,400 & 16,800 & 10,500 & 863,000 \\
\hline 1954 & 9,900 & 13,000 & 12,300 & 25,900 & 199,000 & 216,000 & 196,000 & 67,600 & 45,900 & 45,300 & 36,100 & 19,500 & 887,000 \\
\hline 1955 & 9,040 & 8,000 & 6,580 & 15,900 & 91,700 & 223,000 & 138,000 & 49,100 & 21,600 & 49,800 & 28,000 & 24,800 & 666,000 \\
\hline 1956 & 14,300 & 9,380 & 12,500 & 31,200 & 172,000 & 216,000 & 125,000 & 50,900 & 26,200 & 31,500 & 18,300 & 12,500 & 719,000 \\
\hline 1957 & 8,490 & 9,500 & 10,600 & 16,400 & 219,000 & 175,000 & 66,200 & 29,400 & 18,000 & 20,400 & 21,100 & 10,800 & 606,000 \\
\hline 1958 & 6,210 & 9,330 & 11,100 & 23,900 & 169,000 & 169,000 & 72,700 & 34,200 & 28,700 & 32,500 & 22,300 & 24,500 & 604,000 \\
\hline 1959 & 20,500 & 13,300 & 12,900 & 41,800 & 130,000 & 241,000 & 131,000 & 49,100 & 61,600 & 60,200 & 36,500 & 22,700 & 821,000 \\
\hline 1960 & 13,100 & 9,320 & 13,700 & 40,900 & 85,300 & 181,000 & 98,600 & 39,700 & 22,300 & 14,600 & 13,900 & 10,800 & 544,000 \\
\hline 1961 & 8,550 & 12,200 & 13,100 & 24,700 & 137,000 & 225,000 & 81,400 & 34,800 & 24,200 & 40,500 & 19,200 & 10,600 & 630,000 \\
\hline 1962 & 9,100 & 12,400 & 9,280 & 48,000 & 113,000 & 154,000 & 77,800 & 44,800 & 25,900 & 31,700 & 28,600 & 24,000 & 579,000 \\
\hline 1963 & 11,800 & 23,500 & 11,600 & 20,700 & 108,000 & 202,000 & 105,000 & 34,100 & 24,100 & 16,700 & 13,000 & 9,960 & 581,000 \\
\hline 1964 & 6,210 & 8,280 & 6,830 & 11,800 & 122,000 & 382,000 & 129,000 & 41,100 & 35,300 & 43,300 & 21,800 & 12,000 & 819,000 \\
\hline 1965 & 9,530 & 12,300 & 12,300 & 39,600 & 131,000 & 247,000 & 125,000 & 53,800 & 37,700 & 37,400 & 22,600 & 15,100 & 743,000 \\
\hline 1966 & & 8,550 & & & & & 109,000 & & 900 & 22,200 & & 15,000 & 643,000 \\
\hline 1967 & 11,400 & 11,300 & 10,600 & 16,600 & 152,000 & 270,000 & 152,000 & 49,100 & 23,000 & 18,900 & 28,000 & 15,100 & 758,000 \\
\hline 1968 & 14,300 & 16,800 & 20,400 & 17,300 & 117,000 & 192,000 & 98,000 & 48,100 & 62,800 & 49,300 & 27,200 & 14,300 & 678,000 \\
\hline 1969 & 13,000 & 10,200 & 14,300 & 54,900 & 125,000 & 182,000 & 103,000 & 31,000 & 19,200 & 28,200 & 18,300 & 9,900 & 609,000 \\
\hline 1970 & 8,360 & 8,110 & 9,100 & 11,500 & 150,000 & 271,000 & 87,400 & 36,300 & 24,200 & 18,000 & 11,900 & 13,000 & 649,000 \\
\hline
\end{tabular}


Table 6. Synthesized streamflow volumes for St. Mary River at International Boundary, 1928-1989, in acre-feet (Continued)

\begin{tabular}{|c|c|c|c|c|c|c|c|c|c|c|c|c|c|}
\hline YEAR & JAN. & FEB. & MAR. & APR. & MAY & JUNE & JULY & AUG. & SEPT. & OCT. & NOV. & DEC. & TOTAL \\
\hline 1971 & 11,800 & 18,600 & 12,100 & 34,300 & 179,000 & 219,000 & 140,000 & 64,700 & 26,600 & 26,600 & 17,900 & 10,300 & 760,000 \\
\hline 1972 & 7,560 & 11,000 & 39,700 & 44,700 & 170,000 & 259,000 & 141,000 & 75,000 & 35,800 & 28,100 & 13,700 & 9,590 & 834,000 \\
\hline 1973 & 11,400 & 10,800 & 9,220 & 16,100 & 106,000 & 152,000 & 67,700 & 31,400 & 19,200 & 14,800 & 32,500 & 16,400 & 487,000 \\
\hline 1974 & 25,800 & 18,000 & 13,100 & 32,800 & 123,000 & 271,000 & 159,000 & 59,600 & 30,200 & 13,100 & 10,400 & 9,410 & 766,000 \\
\hline 1975 & 6,640 & 7,110 & 7,010 & 9,820 & 108,000 & 379,000 & 188,000 & 64,900 & 40,100 & 40,600 & 34,400 & 41,100 & 926,000 \\
\hline 1976 & 18,800 & 14,000 & 12,100 & 43,300 & 161,000 & 130,000 & 123,000 & 73,100 & 31,800 & 18,000 & 9,400 & 8,300 & 643,000 \\
\hline 1977 & 6,830 & 6,940 & 6,580 & 20,300 & 80,200 & 80,500 & 44,600 & 41,600 & 43,500 & 18,800 & 14,500 & 18,400 & 383,000 \\
\hline 1978 & 9,280 & 7,280 & 9.470 & 33,100 & 130,000 & 183,000 & 132,000 & 62,400 & 54,600 & 25,900 & 19,000 & 11,400 & 678,000 \\
\hline 1979 & 6,580 & 6,720 & 17,200 & 28,300 & 153,000 & 169,000 & 80,700 & 32,200 & 21,100 & 10,900 & 7,910 & 10,400 & 545,000 \\
\hline 1980 & 7,130 & 6,100 & 4,980 & 47,500 & 180,000 & 149,000 & 66,000 & 36,300 & 45,100 & 27,200 & 28,300 & 24,300 & 622,000 \\
\hline 1981 & 28,200 & 16,100 & 11,800 & 32,700 & 180,000 & 156,000 & 103,000 & 42,200 & 18,800 & 13,500 & 8,930 & 7,750 & 620,000 \\
\hline 1982 & 5,720 & 11,100 & 12,900 & 17,400 & 104,000 & 212,000 & 128,000 & 48,900 & 22,700 & 22,400 & 14,100 & 9,350 & 609,000 \\
\hline 1983 & 8,920 & 7,280 & 8,920 & 21,800 & 92,200 & 133,000 & 97,200 & 42,500 & 22,000 & 11,100 & 23,300 & 9,590 & 478,000 \\
\hline 1984 & 21,200 & 8,340 & 4,980 & 25,900 & 78,000 & 148,000 & 88,500 & 38,900 & 28,100 & 26,000 & 17,000 & 8,180 & 493,000 \\
\hline 1985 & 6,640 & 5,330 & 3,870 & 32,000 & 140,000 & 160,000 & 63.900 & 35,300 & 58,400 & 54,200 & 48,900 & 13,200 & 622,000 \\
\hline 1986 & 11,300 & 20,400 & 39,900 & 51,900 & 110,000 & 157,000 & 63,300 & 29,200 & 31,100 & 35,800 & 26,100 & 13,200 & 589,000 \\
\hline 1987 & 10,100 & 7,890 & 12,900 & 48,700 & 154,000 & 104,000 & 88,100 & 53,200 & 27,600 & 11,000 & 6,250 & 7,260 & 531,000 \\
\hline 1988 & 5,530 & 6,500 & 6,390 & 48,900 & 120,000 & 117,000 & 47,300 & 22,700 & 12,000 & 34,700 & 27,000 & 11,900 & 459,000 \\
\hline 1989 & 9,530 & 7,280 & 9,720 & 44,000 & 128,000 & 209,000 & 107,000 & 57,400 & 51,700 & 32,300 & 79,100 & 32,100 & 766,000 \\
\hline
\end{tabular}


Table 7. Synthesized streamflow volumes for Milk River at Western Crossing of International Boundary, 1928-1989, in acrefeet

\begin{tabular}{|c|c|c|c|c|c|c|c|c|c|c|c|c|c|}
\hline YEAR & JAN. & FEB. & MAR. & APR. & MAY & JUNE & JULY & AUG. & SEPT. & OCT. & NOV. & DEC. & TOTAL \\
\hline 1928 & 1,640 & 380 & 15,800 & 13,400 & 20,600 & 7,400 & 21,500 & 8,760 & 988 & 1,750 & 411 & 105 & 92,800 \\
\hline 1929 & 43 & 17 & 9,970 & 15,400 & 22,000 & 6,400 & 5,410 & 1,610 & 71 & 2,260 & 161 & 55 & 63,400 \\
\hline 1930 & 6.1 & 2,490 & 8,420 & 21,900 & 13,900 & 6,370 & 1,970 & 824 & 280 & 1,190 & 54 & 80 & 57,400 \\
\hline 1931 & 25 & 33 & 2,320 & 3,840 & 2,100 & 530 & 166 & 228 & 405 & 578 & 71 & 0 & 10,300 \\
\hline 1932 & 0 & 345 & 5,850 & 6,660 & 7,930 & 4,850 & 947 & 596 & 303 & 689 & 18 & 0 & 28,200 \\
\hline 1933 & 0 & 0 & 2,170 & 8,750 & 15,200 & 6,840 & 1,490 & 572 & 684 & 1,200 & 220 & 0 & 37,200 \\
\hline 1934 & 105 & 1,440 & 9,040 & 17,600 & 10,500 & 11,600 & 2,710 & 633 & 982 & 2,220 & 71 & 0 & 56,900 \\
\hline 1935 & 49 & 2,050 & 2,470 & 20,200 & 11,400 & 4,650 & 947 & 295 & 393 & 658 & 0 & 0 & 43,100 \\
\hline 1936 & 0 & 0 & 3,060 & 13,200 & 3,540 & 976 & 0 & 12 & 0 & 0 & 0 & 0 & 20,700 \\
\hline 1937 & 0 & 0 & 621 & 15,400 & 10,300 & 14,300 & 1,520 & 547 & 494 & 861 & 0 & 0 & 44,000 \\
\hline 1938 & 0 & 0 & 4,760 & 10,500 & 12,200 & 7,020 & 4,800 & 1,080 & 559 & 928 & 309 & 0 & 42,200 \\
\hline 1939 & 0 & 0 & 6,520 & 5,390 & 3,280 & 2,380 & 191 & 0 & 0 & 129 & 214 & 898 & 19,000 \\
\hline 1940 & 135 & 426 & 2,700 & 5,270 & 2,410 & 399 & 221 & 12 & 0 & 301 & 934 & 590 & 13,400 \\
\hline 1941 & 406 & 355 & 1,480 & 2,470 & 818 & 1,860 & 1,020 & 12 & 351 & 615 & 666 & 1,090 & 11,100 \\
\hline 1942 & 228 & 317 & 1,330 & 14,600 & 8,120 & 11,200 & 2,820 & 1,540 & 1,330 & 1,110 & 2,040 & 978 & 45,600 \\
\hline 1943 & 824 & 733 & 6,940 & 18,400 & 14,900 & 19,200 & 5,890 & 1,710 & 1,060 & 1,330 & 2,370 & 1,170 & 74,600 \\
\hline 1944 & 769 & 690 & 959 & 3,530 & 1,440 & 1,170 & 295 & 49 & 0 & 86 & 934 & 510 & 10,400 \\
\hline 1945 & 406 & 1,060 & 1,530 & 2,520 & 4,810 & 8,810 & 1,690 & 105 & 321 & 670 & 464 & 461 & 22,800 \\
\hline 1946 & 473 & 1,380 & 2,960 & 4,240 & 4,270 & 2,870 & 1,130 & 178 & 744 & 1,650 & 417 & 523 & 20,800 \\
\hline 1947 & 744 & 600 & 17,300 & 18,300 & 14,700 & 7,850 & 2,260 & 1,450 & 2,170 & 2,320 & 1,070 & 873 & 69,700 \\
\hline 1948 & 664 & 339 & 1,570 & 29,800 & 22,900 & 45,300 & 11,200 & 4,210 & 1,800 & 2,080 & 1,960 & 381 & 122,000 \\
\hline 1949 & 135 & 128 & 2,410 & 16,400 & 8,610 & 3,310 & 1,150 & 178 & 571 & 1,610 & 506 & 184 & 35,200 \\
\hline 1950 & 123 & 189 & 2,430 & 22,800 & 26,900 & 22,600 & 9,280 & 3,040 & 1,300 & 2,080 & 684 & 486 & 92,000 \\
\hline 1951 & 418 & 439 & 4,590 & 30,200 & 31,000 & 30,300 & 21,400 & 8,730 & 10,000 & 8,180 & 2,730 & 1,450 & 149,000 \\
\hline 1952 & 818 & 1,950 & 9,780 & 32,800 & 14,300 & 6,490 & 3,340 & 1,540 & 1,120 & 1,220 & 1,610 & 830 & 75,800 \\
\hline 1953 & 658 & 733 & 3,210 & 26,700 & 27,700 & 52,200 & 8,790 & 3,330 & 2,300 & 2,230 & 1,890 & 1,290 & 131,000 \\
\hline 1954 & 1,010 & 4,870 & 4,560 & 22,300 & 36,300 & 16,000 & 5,280 & 3,090 & 2,960 & 3,810 & 2,640 & 2,130 & 105,000 \\
\hline 1955 & 1,190 & 983 & 2,200 & 17,500 & 27,500 & 11,800 & 7,380 & 1,460 & 774 & 1,540 & 1,840 & 1,450 & 75,600 \\
\hline 1956 & 1,230 & 1,020 & 6,020 & 13,000 & 18,600 & 8,990 & 7,750 & 2,850 & 1,370 & 1,430 & 1,150 & 959 & 64,300 \\
\hline 1957 & 750 & 811 & 4,430 & 13,000 & 21,100 & 8,990 & 1,350 & 437 & 881 & 1,490 & 1,390 & 984 & 55,600 \\
\hline 1958 & 805 & 600 & 2,720 & 16,400 & 5,850 & 6,960 & 3,530 & 855 & 655 & 1,400 & 643 & 824 & 41,200 \\
\hline 1959 & 492 & 572 & 7,870 & 17,000 & 20,500 & 9,220 & 2,690 & 805 & 1,090 & 2,230 & 994 & 1,420 & 65,000 \\
\hline 1960 & 646 & 2,100 & 17,600 & 6,550 & 12,400 & 3,590 & 744 & 547 & 0 & 301 & 893 & 590 & 46,000 \\
\hline 1961 & 590 & 555 & 4,180 & 4,390 & 10,600 & 2,960 & 664 & 80 & 179 & 1,060 & 565 & 264 & 26,100 \\
\hline 1962 & 301 & 461 & 7,010 & 15,900 & 6,640 & 3,300 & 609 & 295 & 137 & 633 & 768 & 842 & 36,900 \\
\hline 1963 & 529 & 5,500 & 2,710 & 3,250 & 3,190 & 4,670 & 2,560 & 6.1 & 0 & 0 & 887 & 670 & 24,000 \\
\hline 1964 & 670 & 656 & 1,340 & 7,200 & 20,800 & 32,600 & 4,620 & 1,130 & 2,240 & 2,350 & 684 & 916 & 75,300 \\
\hline 1965 & 781 & 855 & 6,150 & 31,400 & 17,500 & 15,900 & 5,340 & 1,600 & 3,280 & 1,990 & 4,200 & 2,240 & 91,300 \\
\hline 1966 & 1,260 & 1,110 & 9,470 & 11,400 & 7,990 & 17,000 & 5,020 & 1,610 & 958 & 1,880 & 1,360 & 1,020 & 60,100 \\
\hline 1967 & 916 & 883 & 7,260 & 12,700 & 41,800 & 26,500 & 5,280 & 1,400 & 589 & 1,290 & 833 & 1,280 & 101,000 \\
\hline 1968 & 861 & 1,130 & 6,460 & 6,780 & 12,300 & 9,580 & 2,660 & 1,980 & 5,880 & 3,640 & 2,550 & 1,150 & 55,000 \\
\hline 1969 & 750 & 977 & 5,610 & 36,600 & 8,050 & 13,900 & 6,150 & 615 & 309 & 1,560 & 1,020 & 1,280 & 76,800 \\
\hline 1970 & 781 & 739 & 1,420 & 7,140 & 24,700 & 11,600 & 2,580 & 879 & 768 & 1,170 & 1,340 & 996 & 54,100 \\
\hline
\end{tabular}


Table 7. Synthesized streamflow volumes for Milk River at Western Crossing of International Boundary, 1928-1989, in acrefeet (Continued)

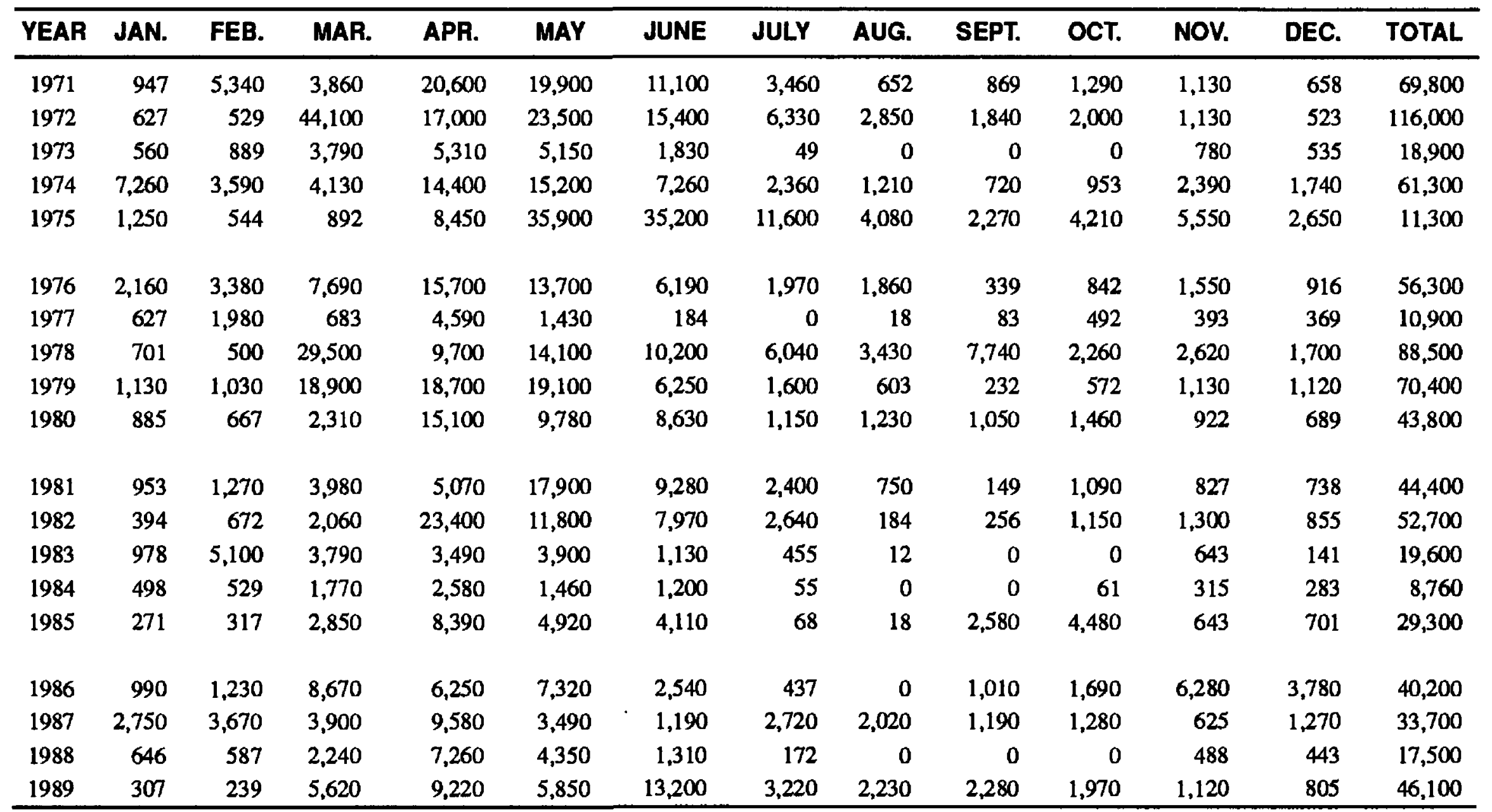


Table 8. Synthesized streamflow volumes for Milk River at Eastern Crossing of International Boundany, 1928-89, in acre-feet

\begin{tabular}{|c|c|c|c|c|c|c|c|c|c|c|c|c|c|}
\hline YEAR & JAN. & FEB. & MAR. & APR. & MAY & JUNE & JULY & AUG. & SEPT. & OCT. & NOV. & DEC. & TOTAL \\
\hline 1928 & 16,100 & 6,970 & 68,400 & 36,400 & 28,500 & 27,500 & 37,000 & 9,040 & 9,220 & 8,490 & 7,120 & 3,570 & 258,000 \\
\hline 1929 & 2,590 & 2,210 & 27,100 & 40,800 & 38,700 & 37,000 & 2,840 & 55 & 1,300 & 3,950 & 4,070 & 2,670 & 163,000 \\
\hline 1930 & 1,890 & 21,000 & 25,900 & 35,800 & 25,900 & 9,280 & 2,370 & 1,390 & 3,940 & 3,330 & 2,810 & 3,170 & 137,000 \\
\hline 1931 & 2,260 & 2,500 & 7,990 & 6,550 & 4,100 & 4,470 & 2,280 & 3,730 & 3,640 & 0 & 2,760 & 842 & 41,100 \\
\hline 1932 & 1,030 & 5,830 & 15,200 & 16,400 & 14,700 & 22,800 & 2,730 & 2,110 & 2,750 & 1,620 & 2,160 & 695 & 88,000 \\
\hline 1933 & 588 & 1,230 & 16,400 & 38,000 & 28,500 & 11,400 & 438 & 0 & 0 & 3,420 & 4,880 & 1,290 & 106,000 \\
\hline 1934 & 3,380 & 15,100 & 22,500 & 21,700 & 16,500 & 22,700 & 4,750 & 1,200 & 4,660 & 3,580 & 5,660 & 3,780 & 126,000 \\
\hline 1935 & 8,520 & 17,900 & 12,400 & 34,800 & 19,000 & 7,620 & 3,420 & 1,680 & 768 & 2,380 & 79 & 143 & 109,000 \\
\hline 1936 & 66 & 17 & 20,800 & 29,900 & 7,010 & 5,270 & 738 & 2,410 & 839 & 793 & 1,950 & 207 & 70,000 \\
\hline 1937 & 62 & 62 & 4,240 & 34,800 & 19,100 & 23,700 & 5,040 & 601 & 2,130 & 3,980 & 1,090 & 560 & 95,300 \\
\hline 1938 & 883 & 512 & 28,100 & 24,400 & 25,800 & 15,400 & 9,720 & 2,020 & 3,820 & 1.710 & 3,430 & 676 & 116,000 \\
\hline 1939 & 397 & 235 & 12,900 & 7,850 & 4,500 & 10,000 & 3,830 & 1,510 & 2,290 & 812 & 2,130 & 159 & 46,600 \\
\hline 1940 & 38 & 17 & 19,100 & 16,200 & 9,840 & 4,120 & 5,290 & 885 & 2,370 & 1,740 & 2,430 & 283 & 62,300 \\
\hline 1941 & 183 & 226 & 6,270 & 4,580 & 4,190 & 6,960 & 2,160 & 849 & 1,360 & 1,990 & 1,290 & 1,770 & 31,800 \\
\hline 1942 & 366 & 1,330 & 5,080 & 31,500 & 15,100 & 24,100 & 6,270 & 689 & 1,980 & 3,830 & 1,740 & 1,980 & 93,900 \\
\hline 1943 & 524 & 1,140 & 21,800 & 36,800 & 21,000 & 25,200 & 7,500 & 2,050 & 1,200 & 3,880 & 4,210 & 1,400 & 127,000 \\
\hline 1944 & 766 & 1,190 & 3,310 & 8,630 & 3,780 & 3,830 & 1,920 & 2,250 & 1,080 & 898 & 1,030 & 800 & 29,500 \\
\hline 1945 & 319 & 659 & 13,700 & 4,770 & 8,300 & 14,100 & 2,320 & 12 & 1,010 & 2,480 & 1,360 & 1,330 & 50,300 \\
\hline 1946 & 750 & 1,390 & 11,500 & 5,610 & 6,890 & 8,570 & 2,900 & 941 & 2,680 & 5,710 & 1,540 & 1,080 & 49,500 \\
\hline 1947 & 1,000 & 3,580 & 73,200 & 41,200 & 23,700 & 13,600 & 2,720 & 3,710 & 5,190 & 4,990 & 2,390 & 1,720 & 177,000 \\
\hline 1948 & 1,980 & 631 & 10,200 & 66,600 & 40,500 & 57,500 & 20,200 & 7,260 & 1,090 & 5,430 & 3,930 & 2,350 & 218,000 \\
\hline 1949 & 1,200 & 942 & 8,300 & 23,900 & 15,600 & 5,450 & 1,250 & 71 & 863 & 4,330 & 3,120 & 1,120 & 66,100 \\
\hline 1950 & 65 & 700 & 8,300 & 38,000 & 31,100 & 28,400 & 10,500 & 4,270 & 750 & 2,530 & 4,640 & 1,690 & 131,000 \\
\hline 1951 & 1,350 & 959 & 32,600 & 59,500 & 47,800 & 52,800 & 35,100 & 15,400 & 19,500 & 17,700 & 12,900 & 7,950 & 304,000 \\
\hline 1952 & 5,140 & 9,360 & 59,000 & 85,100 & 30,300 & 13,400 & 7,810 & 3,170 & 2,390 & 3,420 & 3,360 & 3,400 & 226,000 \\
\hline 1953 & 3,550 & 4,590 & 10,100 & 48,300 & 52,000 & 117,000 & 18,500 & 4,950 & 3,470 & 6,010 & 5,210 & 3,670 & 277,000 \\
\hline 1954 & 2,500 & 8,930 & 9,960 & 44,100 & 44,400 & 24,000 & 5,920 & 6,270 & 8,570 & 7,190 & 4,470 & 2,880 & 169,000 \\
\hline 1955 & 1,180 & 1,330 & 5,600 & 48,100 & 53,500 & 20,500 & 27,500 & 474 & 2,130 & 5,000 & 1,830 & 2,520 & 170,000 \\
\hline 1956 & 1,890 & 2,350 & 18,800 & 29,100 & 24,500 & 13,700 & 14,800 & 7,930 & 2,800 & 4,100 & 4,550 & 1,480 & 126,000 \\
\hline 1957 & 1,150 & 2,810 & 26,700 & 22,800 & 29,700 & 15,500 & 928 & 1,700 & 3,490 & 6,890 & 4,900 & 2,940 & 120,000 \\
\hline 1958 & 1,900 & 3,440 & 12,400 & 67,800 & 11,800 & 12,900 & 5,190 & 824 & 1,580 & 3,620 & 3,120 & 3,310 & 128,000 \\
\hline 1959 & 2,310 & 2,380 & 42,900 & 31,400 & 27,600 & 15,700 & 5,210 & 1,690 & 3,170 & 4,720 & 3,880 & 4,860 & 146,000 \\
\hline 1960 & 2,050 & 2,500 & 46,300 & 18,300 & 26,100 & 5,620 & 492 & 1,130 & 922 & 2,490 & 2,090 & 1,820 & 110,000 \\
\hline 1961 & 2,150 & 2,780 & 7,560 & 5,190 & 15,800 & 7,020 & 461 & 504 & 1,060 & 3,350 & 2,320 & 619 & 48,800 \\
\hline 1962 & 2,400 & 4,470 & 18,100 & 22,500 & 9,720 & 6,430 & 1,110 & 18 & 2,230 & 1,430 & 1,560 & 1,400 & 71,400 \\
\hline 1963 & 628 & 10,400 & 6,700 & 3,490 & 4,950 & 6,900 & 4,640 & 916 & 1,510 & 1,650 & 762 & 483 & 43,000 \\
\hline 1964 & 424 & 1,260 & 2,720 & 15,900 & 45,300 & 43,400 & 8,420 & 2.650 & 3,470 & 6,030 & 3,900 & 1,830 & 135,000 \\
\hline 1965 & 757 & 5,900 & 19,800 & 101,000 & 30,400 & 46,200 & 15,900 & 3,970 & 8,450 & 7,560 & 4,140 & 4,380 & 248,000 \\
\hline 1966 & 683 & 1,810 & 29,800 & 23,800 & 14,700 & 28,900 & 11.700 & 4,160 & 1,920 & 6,950 & 3,500 & 2,550 & 130,000 \\
\hline 1967 & 2,670 & 4,780 & 39,000 & 41,400 & 109,000 & 47,200 & 7,190 & 3,170 & 1,720 & 4,510 & 4,070 & 2,860 & 268,000 \\
\hline 1968 & 2,760 & 5,710 & 24,800 & 13,500 & 22,100 & 16,400 & 7,810 & 6,950 & 11,100 & 13,200 & 7,110 & 4,430 & 136,000 \\
\hline 1969 & 1,600 & 2,500 & 57,600 & 72,600 & 19,200 & 18,600 & 18,400 & 1,570 & 2,020 & 4,610 & 4,170 & 2,570 & 205,000 \\
\hline 1970 & 945 & 2,160 & 16,000 & 17,600 & 32,100 & 21,500 & 5,070 & 3,500 & 4,340 & 3,810 & 3,880 & 1,280 & 112,000 \\
\hline
\end{tabular}


Table 8. Synthesized streamflow volumes for Milk River at Eastern Crossing of International Boundary, 1928-89, in acre-feet (Continued)

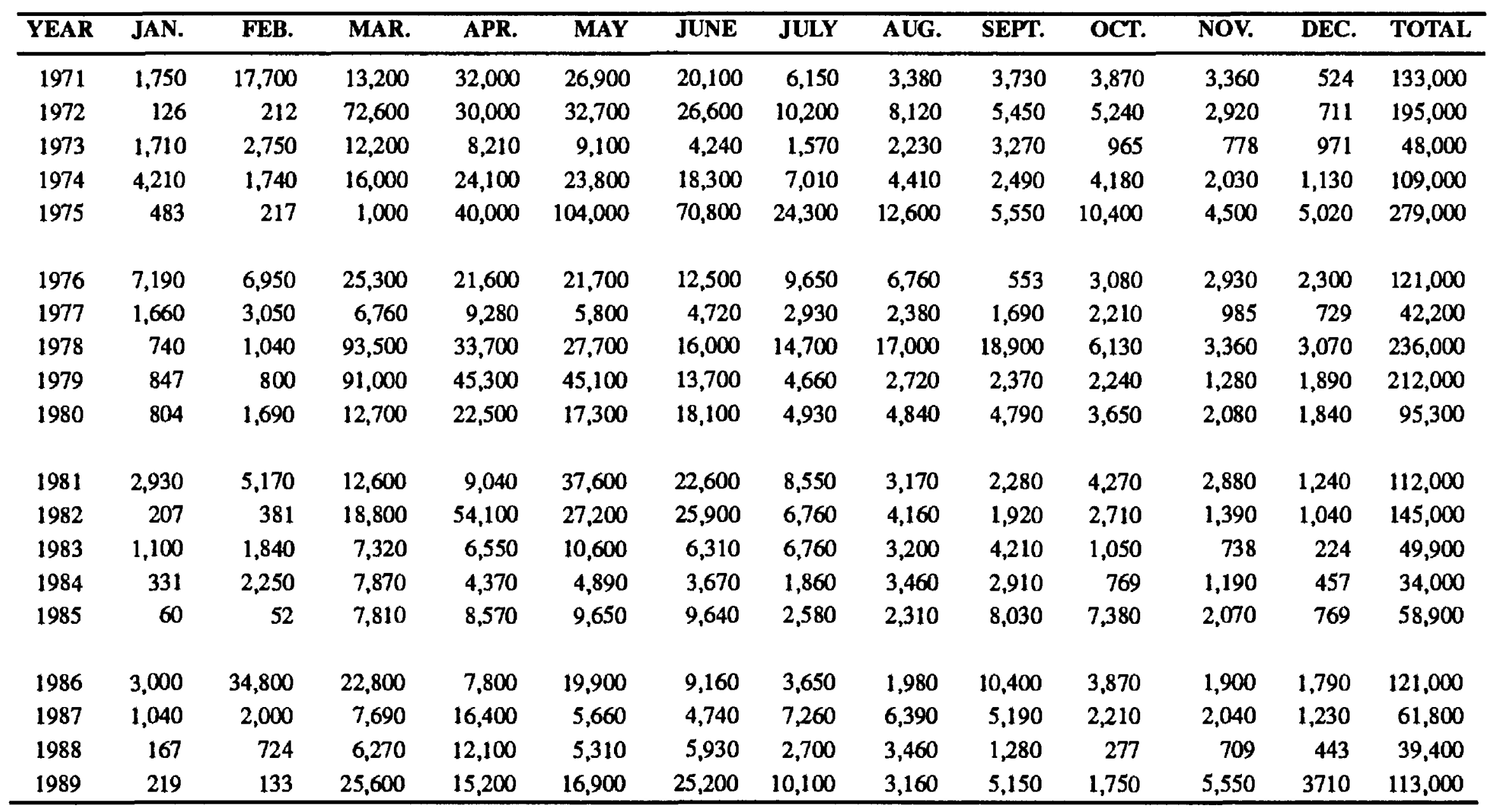


Table 9. Synthesized streamflow volumes for Milk River below Fresno Reservoir, Montana, 1928-89, in acre feet

\begin{tabular}{|c|c|c|c|c|c|c|c|c|c|c|c|c|c|}
\hline YEAR & JAN. & FEB. & MAR. & APR. & MAY & JUNE & JULY & AUG. & SEPT. & OCT. & NOV. & DEC. & TOTAL \\
\hline 1928 & 16,100 & 6,970 & 84,400 & 51,400 & 28,600 & 27,600 & 39,100 & 9,210 & 9,260 & 8,520 & 7,120 & 3,570 & 292,000 \\
\hline 1929 & 2,590 & 2,200 & 27,200 & 41,200 & 39,200 & 37,500 & 2,840 & 55 & 1,300 & 3,970 & 4,070 & 2,660 & 165,000 \\
\hline 1930 & 1,890 & 21,200 & 40,900 & 42,200 & 26,000 & 9,290 & 2,460 & 1,390 & 3,950 & 3,330 & 2,810 & 3,170 & 159,000 \\
\hline 1931 & 2,260 & 2,500 & 8,020 & 6,570 & 4,110 & 4,940 & 2,430 & 3,740 & 3,650 & 6.1 & 2,760 & 842 & 41,800 \\
\hline 1932 & 1,030 & 5,830 & 16,100 & 16,700 & 14,800 & 23,500 & 2,740 & 2,110 & 2,760 & 1,640 & 2,150 & 695 & 90,000 \\
\hline 1933 & 590 & 1,230 & 16,400 & 38,000 & 28,500 & 11,600 & 480 & 37 & 6.0 & 3,430 & 4,880 & 1,290 & 106,000 \\
\hline 1934 & 3,380 & 15,700 & 24,500 & 21,900 & 16,500 & 22,700 & 4,750 & 1,200 & 4,670 & 3,590 & 5,660 & 3,790 & 128,000 \\
\hline 1935 & 8,520 & 17,800 & 16,500 & 39,800 & 19,000 & 7,620 & 5,120 & 1,680 & 774 & 2,390 & 77 & 141 & 119,000 \\
\hline 1936 & 68 & 17 & 20,900 & 42,000 & 7,020 & 5,270 & 738 & 2,410 & 839 & 799 & 1,960 & 209 & 82,200 \\
\hline 1937 & 61 & 61 & 4,910 & 39,400 & 19,100 & 23,700 & 5,050 & 603 & 2,170 & 3,990 & 1,090 & 560 & 101,000 \\
\hline 1938 & 885 & 511 & 33,500 & 27,100 & 26,200 & 16,000 & 10,100 & 2,020 & 3,820 & 1,710 & 3,430 & 676 & 126,000 \\
\hline 1939 & 400 & 233 & 36,500 & 7,940 & 4,690 & 13,400 & 3,860 & 1,510 & 2,290 & 818 & 2,130 & 160 & 73,900 \\
\hline 1940 & 37 & 17 & 19,100 & 37,500 & 10,600 & 4,560 & 5,290 & 885 & 2,370 & 1,750 & 2.430 & 283 & 84,800 \\
\hline 1941 & 184 & 228 & 21,100 & 4,670 & 4,210 & 7,020 & 2,280 & 849 & 1,360 & 1,990 & 1,290 & 1,760 & 46,900 \\
\hline 1942 & 369 & 1,330 & 8,200 & 32,400 & 15,100 & 27,500 & 6,540 & 689 & 1,990 & 3,840 & 1,740 & 1,990 & 102,000 \\
\hline 1943 & 523 & 1,140 & 50,700 & 39,000 & 21,100 & 25,200 & 7,530 & 2,050 & 1,200 & 3,880 & 4,210 & 1,400 & 158,000 \\
\hline 1944 & 769 & 1,190 & 6,060 & 8,750 & 3,810 & 3,860 & 2,360 & 5,370 & 1,080 & 904 & 1,020 & 799 & 36,000 \\
\hline 1945 & 320 & 661 & 16,800 & 4,790 & 8,320 & 14,100 & 2,320 & 12 & 1,010 & 2,480 & 1,360 & 1,330 & 53,600 \\
\hline 1946 & 750 & 1,390 & 17,400 & 5,630 & 6,890 & 8,950 & 2,900 & 941 & 2,680 & 5,720 & 1,540 & 1,080 & 55,900 \\
\hline 1947 & 1,000 & 3,580 & 78,400 & 42,500 & 23,700 & 13,600 & 2,720 & 3,710 & 5,190 & 4,990 & 2,390 & 1,720 & 184,000 \\
\hline 1948 & 1,970 & 633 & 10,200 & 66,700 & 40,500 & 57,500 & 20,200 & 7,260 & 1,090 & 5,430 & 3,930 & 2,360 & 218,000 \\
\hline 1949 & 1,200 & 944 & 8,360 & 23,900 & 15,600 & 5,450 & 1,250 & 74 & 863 & 4,330 & 3,120 & 1,120 & 66,200 \\
\hline 1950 & 61 & 700 & 8,300 & 67,300 & 31,100 & 28,500 & 10,500 & 4,270 & 750 & 2,540 & 4,640 & 1,680 & 160,000 \\
\hline 1951 & 1,350 & 961 & 32,600 & 66,600 & 49,200 & 52,800 & 35,100 & 15,400 & 19,500 & 17,700 & 12,900 & 7,950 & 312,000 \\
\hline 1952 & 5,140 & 9,360 & 59,000 & 190,000 & 30,600 & 13,400 & 8,260 & 3,170 & 2,400 & 3,420 & 3,360 & 3,400 & 332,000 \\
\hline 1953 & 3,550 & 4,590 & 10,600 & 48,500 & 52,600 & 117,000 & 18,600 & 4,950 & 3,470 & 6,010 & 5,210 & 3,660 & 279,000 \\
\hline 1954 & 2,500 & 8,920 & 10,000 & 59,200 & 44,500 & 24,200 & 5,930 & 6,360 & 8,600 & 7,270 & 4,470 & 2,880 & 185,000 \\
\hline 1955 & 1,180 & 1,330 & 10,800 & 71,900 & 54,300 & 20,900 & 47,400 & 603 & 2,140 & 5,020 & 1,830 & 2,520 & 220,000 \\
\hline 1956 & 1,890 & 2,350 & 19,100 & 29,800 & 24,700 & 13,700 & 14,800 & 7,930 & 2,800 & 4,100 & 4,550 & 1,480 & 127,000 \\
\hline 1957 & 1,150 & 2,810 & 27,200 & 26,900 & 29,700 & 15,500 & 1,160 & 1,700 & 3,490 & 6,890 & 4,900 & 2,940 & 124,000 \\
\hline 1958 & 1,900 & 3,440 & 22,700 & 71,500 & 11,800 & 12,900 & 5,190 & 824 & 1,580 & 3,620 & 3,120 & 3,310 & 142,000 \\
\hline 1959 & 2,310 & 2,380 & 49,700 & 32,000 & 27,600 & 17,100 & 5,260 & 1,690 & 3,170 & 4,730 & 3,880 & 4,860 & 155,000 \\
\hline 1960 & 2,050 & 2,500 & 64,900 & 18,700 & 26,700 & 5,620 & 492 & 1,130 & 922 & 2,500 & 2,080 & 1,820 & 129,000 \\
\hline 1961 & 2,150 & 2,780 & 15,400 & 5,220 & 15,800 & 7,450 & 461 & 504 & 1,060 & 3,360 & 2,320 & 621 & 57,100 \\
\hline 1962 & 2,400 & 4,480 & 24,000 & 22,900 & 9,730 & 6,650 & 11,100 & 61 & 2,230 & 1,450 & 1,560 & 1,400 & 88,000 \\
\hline 1963 & 627 & 10,500 & 7,330 & 3,550 & 4,970 & 6,940 & 4,640 & 916 & 1,510 & 1,660 & 762 & 486 & 43,800 \\
\hline 1964 & 424 & 1,250 & 2,720 & 16,000 & 45,300 & 43,400 & 8,420 & 2,650 & 3,480 & 6,040 & 3,900 & 1,830 & 135,000 \\
\hline 1965 & 756 & 5,900 & 19,800 & 107,000 & 30,500 & 46,300 & 16,000 & 3,970 & 8,460 & 7,580 & 4,140 & 4,380 & 255,000 \\
\hline 1966 & 683 & 1,810 & 40,900 & 24,400 & 14,800 & 28,900 & 11,700 & 4,160 & 1,920 & 6,950 & 3,500 & 2,550 & 142,000 \\
\hline 1967 & 2,660 & 4,780 & 44,700 & 56,500 & 115,000 & 47,300 & 7,190 & 3,170 & 1,720 & 4,520 & 4,070 & 2,850 & 294,000 \\
\hline 1968 & 2,760 & 5,710 & 24,900 & 13,500 & 22,200 & 16,400 & 7,810 & 6,950 & 11,100 & 13,200 & 7,110 & 4,430 & 136,000 \\
\hline 1969 & 1,590 & 2,500 & 57,600 & 86,500 & 19,400 & 18,600 & 18,500 & 1,570 & 2,020 & 4,610 & 4,170 & 2,570 & 220,000 \\
\hline 1970 & 947 & 2,150 & 16,600 & 17,700 & 32,200 & 21,600 & 5,070 & 3,500 & 4,340 & 3,810 & 3,880 & 1,280 & 113,000 \\
\hline
\end{tabular}


Table 9. Synthesized streamflow volumes for Milk River below Fresno Reservoir, Montana, 1928-89, in acre feet (Continued)

\begin{tabular}{|c|c|c|c|c|c|c|c|c|c|c|c|c|c|}
\hline YEAR & JAN. & FEB. & MAR. & APR. & MAY & JUNE & JULY & AUG. & SEPT. & OCT. & NOV. & DEC. & TOTAL \\
\hline 1971 & 1,750 & 17,700 & 13,200 & 32,500 & 27,000 & 20,100 & 6,150 & 3,380 & 3,730 & 3,890 & 3,360 & 523 & 133,000 \\
\hline 1972 & 129 & 213 & 74,400 & 30,000 & 32,700 & 26,600 & 10,200 & 8,120 & 5,450 & 5,250 & 2,920 & 713 & 197,000 \\
\hline 1973 & 1,710 & 2,750 & 12,300 & 8,270 & 9,120 & 4,250 & 1,570 & 2,230 & 3,270 & 972 & 780 & 972 & 48,200 \\
\hline 1974 & 4,210 & 1,740 & 27.900 & 28,500 & 29,300 & 18,400 & 7,010 & 4,410 & 2,500 & 4,190 & 2,030 & 1,130 & 131,000 \\
\hline 1975 & 486 & 217 & 1,030 & 44,100 & 106,000 & 72,300 & 24,700 & 13,500 & 5,570 & 10,400 & 4,500 & 5,020 & 288,000 \\
\hline 1976 & 7,190 & 6,950 & 35,800 & 21,700 & 21,700 & 12,500 & 9,650 & 6,760 & 553 & 3,090 & 2,930 & 2,310 & 131,000 \\
\hline 1977 & 1,660 & 3,050 & 6,810 & 9,350 & 5,820 & 4,730 & 2,930 & 2,380 & 1,690 & 2,220 & 988 & 732 & 42,400 \\
\hline 1978 & 738 & 1,040 & 95,400 & 58,600 & 28,300 & 16,000 & 14,700 & 17,000 & 18,900 & 6,140 & 3,360 & 3,070 & 263,000 \\
\hline 1979 & 849 & 800 & 101,000 & 50,400 & 45,400 & 14,500 & 7,450 & 2,720 & 2,370 & 2,250 & 1,280 & 1,890 & 231,000 \\
\hline 1980 & 805 & 1,690 & 15,000 & 22,600 & 17,300 & 18,100 & 4,930 & 4,840 & 4,790 & 3,650 & 2,090 & 1,850 & 97,600 \\
\hline 1981 & 2,940 & 5,170 & 12,600 & 9,050 & 37,700 & 22,600 & 8,550 & 3,180 & 2,280 & 4,280 & 2,890 & 1,240 & 112,000 \\
\hline 1982 & 215 & 389 & 19,200 & 74,800 & 28,700 & 28,300 & 6,770 & 4,170 & 1,920 & 2,720 & 1,400 & 1,050 & 170,000 \\
\hline 1983 & 1,110 & 1,850 & 7,320 & 6,550 & 10,700 & 6,310 & 7,140 & 3,210 & 4,210 & 1,060 & 744 & 234 & 50,500 \\
\hline 1984 & 338 & 2,260 & 7,880 & 4,380 & 4,900 & 3,730 & 1,860 & 3.470 & 2,910 & 775 & 1,200 & 467 & 34,200 \\
\hline 1985 & 68 & 61 & 7,820 & 8,570 & 9,660 & 9,650 & 2,580 & 2,310 & 8,040 & 7,380 & 2,080 & 775 & 59,000 \\
\hline 1986 & 3,010 & 34,800 & 45,400 & 7,800 & 21,700 & 9,510 & 3,700 & 1,990 & 28,500 & 3,890 & 1,910 & 1,800 & 164,000 \\
\hline 1987 & 1,050 & 2,000 & 9,560 & 16,500 & 5,710 & 4,820 & 7,280 & 6,400 & 5,190 & 2,220 & 2,050 & 1,240 & 64,000 \\
\hline 1988 & 178 & 731 & 6,280 & 12,100 & 5,350 & 5,930 & 2,710 & 3,460 & 1,280 & 283 & 720 & 449 & 39,500 \\
\hline 1989 & 228 & 139 & 25,600 & 15,200 & 16,900 & 25,200 & 10,100 & 3,170 & 5,150 & 1,760 & 5,560 & 3,720 & 113,000 \\
\hline
\end{tabular}


Table 10. Synthesized streamflow volumes for Milk River at Ft. Belknap diversion dam, Montana, 1928-89, in acre-feet

\begin{tabular}{|c|c|c|c|c|c|c|c|c|c|c|c|c|c|}
\hline YEAR & JAN. & FEB. & MAR. & APR. & MAY & JUNE & JULY & AUG. & SEPT. & OCT. & NOV. & DEC. & TOTAL \\
\hline 1928 & 16,100 & 6,980 & 118,000 & 81,000 & 29,400 & 29,700 & 43,800 & 10,100 & 9,370 & 8,880 & 7,120 & 3,790 & 364,000 \\
\hline 1929 & 2,600 & 2,210 & 32,800 & 43,600 & 43,100 & 40,100 & 3,360 & 68 & 1,370 & 4,100 & 4,080 & 2,830 & 180,000 \\
\hline 1930 & 1,890 & 21,600 & 69,600 & 55,900 & 26,100 & 9,600 & 2,920 & 1,430 & 4,020 & 3,480 & 2,810 & 3,360 & 203,000 \\
\hline 1931 & 2,270 & 2,500 & 9,800 & 6,650 & 4,140 & 5,740 & 2,690 & 3,760 & 3,720 & 25 & 2,770 & 867 & 44,900 \\
\hline 1932 & 1,030 & 5,840 & 21,200 & 17,600 & 15,000 & 25,200 & 2,960 & 2,120 & 2,830 & 1,740 & 2,160 & 701 & 98,400 \\
\hline 1933 & 590 & 1,230 & 19,300 & 38,800 & 29,700 & 12,200 & 885 & 98 & 77 & 3,450 & 4,890 & 1,330 & 113,000 \\
\hline 1934 & 3,380 & 16,500 & 31,100 & 22,800 & 16,500 & 23,200 & 4,780 & 1,210 & 4,740 & 3,610 & 5,670 & 3,890 & 137,000 \\
\hline 1935 & 8,530 & 17,900 & 24,700 & 49,300 & 19,200 & 7,970 & 7,830 & 1,690 & 845 & 2,400 & 83 & 172 & 140,000 \\
\hline 1936 & 74 & 23 & 22,700 & 63,900 & 7,130 & 5,330 & 744 & 2,420 & 899 & 818 & 1,970 & 209 & 106,000 \\
\hline 1937 & 148 & 139 & 6,470 & 47,700 & 19,200 & 26,000 & 8,020 & 603 & 2,240 & 4,010 & 1,090 & 560 & 106,000 \\
\hline 1938 & 972 & 994 & 43,100 & 32,200 & 27,500 & 20,100 & 11,400 & 2,050 & 3,960 & 1,790 & 3,590 & 756 & 148,000 \\
\hline 1939 & 523 & 328 & 78,000 & 8,160 & 5,820 & 35,400 & 6,220 & 1,510 & 2,290 & 842 & 2,160 & 246 & 141,000 \\
\hline 1940 & 86 & 109 & 27,300 & 74,900 & 12,800 & 5,700 & 5,400 & 885 & 2,370 & 1,760 & 2,430 & 307 & 134,000 \\
\hline 1941 & 184 & 311 & 49,700 & 5,300 & 4,580 & 11,600 & 2,590 & 916 & 1,380 & 2,270 & 1,680 & 1,820 & 82,300 \\
\hline 1942 & 369 & 3,140 & 17,200 & 43,500 & 18,200 & 33,900 & 7,120 & 793 & 2,020 & 4,110 & 2,010 & 2,080 & 134,000 \\
\hline 1943 & 553 & 35,600 & 102,000 & 44,100 & 23,600 & 28,400 & 8,850 & 2,110 & 1,200 & 4,060 & 4,360 & 1,560 & 256,000 \\
\hline 1944 & 2,810 & 3,530 & 11,200 & 9,920 & 4,310 & 6,280 & 4,190 & 10,400 & 1,120 & 1,160 & 1,210 & 922 & 57,100 \\
\hline 1945 & 381 & 4,330 & 23,100 & 7,380 & 11,400 & 33,000 & 4,020 & 55 & 1,140 & 2,620 & 1,480 & 1,330 & 90,200 \\
\hline 1946 & 750 & 6,400 & 28,300 & 5,930 & 8,020 & 9,780 & 3,010 & 1,140 & 2,710 & 6,310 & 1,660 & 1,190 & 75,200 \\
\hline 1947 & 1,000 & 3,750 & 101,000 & 47,900 & 24,700 & 14,800 & 2,820 & 3,810 & 5,280 & 5,560 & 2,610 & 1,800 & 215,000 \\
\hline 1948 & 1,990 & 1,040 & 19,600 & 85,100 & 48,600 & 59,200 & 20,500 & 7,960 & 1,130 & 6,070 & 4,370 & 2,360 & 258,000 \\
\hline 1949 & 1,200 & 1,090 & 8,970 & 25,500 & 19,800 & 6,360 & 1,370 & 80 & 899 & 4,480 & 3,250 & 1,170 & 74,200 \\
\hline 1950 & 86 & 822 & 10,000 & 120,000 & 32,100 & 28,800 & 10,500 & 4,640 & 774 & 2,640 & 4,780 & 1,730 & 217,000 \\
\hline 1951 & 1,600 & 1,290 & 39,700 & 81,200 & 52,200 & 52,900 & 35,300 & 15,400 & 19,700 & 17,800 & 13,000 & 8,230 & 338,000 \\
\hline 1952 & 5,190 & 12,500 & 76,300 & 379,000 & 32,400 & 14,300 & 9,490 & 3,250 & 2,420 & 3,500 & 3,390 & 3,400 & 545,000 \\
\hline 1953 & 3,550 & 4,620 & 12,200 & 48,900 & 60,200 & 133,000 & 21,100 & 5,420 & 3,500 & 6,110 & 5,690 & 4,060 & 308,000 \\
\hline 1954 & 2,660 & 11,100 & 11,100 & 87,700 & 46,000 & 25,600 & 6,390 & 6,600 & 8,940 & 7,760 & 4,890 & 3,220 & 222,000 \\
\hline 1955 & 1,270 & 1,420 & 22,700 & 124,000 & 67,000 & 24,800 & 80,900 & 1,010 & 2,190 & 5,110 & 1,910 & 2,520 & 335,000 \\
\hline 1956 & 1,890 & 2,350 & 21,000 & 32,100 & 25,400 & 13,800 & 14,900 & 7,940 & 2,800 & 4,110 & 4,550 & 1,480 & 132,000 \\
\hline 1957 & 1,150 & 2,840 & 29.400 & 34,400 & 30,500 & 15,800 & 1,560 & 1,700 & 3,520 & 6,890 & 4,920 & 2,960 & 136,000 \\
\hline 1958 & 1,900 & 3,750 & 40,600 & 77,700 & 11,800 & 12,900 & 5,190 & 824 & 1,580 & 3,620 & 3,120 & 3,470 & 167,000 \\
\hline 1959 & 2,320 & 2,380 & 67,900 & 33,900 & 27,900 & 19,800 & 5,560 & 1,690 & 3,240 & 4,860 & 3,920 & 4,950 & 178,000 \\
\hline 1960 & 2,190 & 2,810 & 102,000 & 20,600 & 28,500 & 6,220 & 781 & 1,180 & 952 & 2,530 & 2,090 & 1,820 & 171,000 \\
\hline 1961 & 2,150 & 2,780 & 28,000 & 5,310 & 16,200 & 8,290 & 461 & 504 & 1,060 & 3,380 & 2,320 & 621 & 71,100 \\
\hline 1962 & 2,400 & 4,600 & 35,000 & 23,600 & 10,400 & 7,380 & 27,700 & 154 & 2,230 & 1,480 & 1,560 & 1,420 & 118,000 \\
\hline 1963 & 633 & 15,600 & 9,150 & 4,000 & 5,230 & 7,120 & 4,770 & 922 & 1,550 & 1,680 & 762 & 486 & 51,900 \\
\hline 1964 & 473 & 1,270 & 2,750 & 16,200 & 49,500 & 47,300 & 9,030 & 2,860 & 3,730 & 6,430 & 4,250 & 1,890 & 146,000 \\
\hline 1965 & 756 & 7,590 & 21,300 & 140,000 & 39,102 & 52,300 & 21,800 & 5,150 & 10,300 & 8,730 & 4,990 & 4,950 & 317,000 \\
\hline 1966 & 750 & 1,900 & 70,700 & 27,300 & 15,500 & 29,200 & 11,800 & 4,240 & 1,920 & 6,950 & 3,530 & 2,610 & 176,000 \\
\hline 1967 & 2,790 & 5,160 & 68,300 & 85,000 & 128,000 & 49,300 & 7,670 & 3,340 & 2,930 & 5,050 & 4,450 & 3,110 & 365,000 \\
\hline 1968 & 4,450 & 7,760 & 27,200 & 14,600 & 22,600 & 17,600 & 8,010 & 7,360 & 11,500 & 13,600 & 7,430 & 4,580 & 147,000 \\
\hline 1969 & 1,600 & 2,500 & 66,800 & 114,000 & 22,000 & 22,200 & 23,500 & 1,920 & 2,090 & 5,150 & 4,810 & 3,170 & 270,000 \\
\hline 1970 & 1,030 & 2,600 & 21,400 & 20,300 & 53,800 & 30,900 & 6,670 & 3,880 & 4,660 & 4,480 & 4,440 & 1,590 & 156,000 \\
\hline
\end{tabular}


Table 10. Synthesized streamflow volumes for Milk River at Ft. Belknap diversion dam, Montana, 1928-89, in acre-feet (Continued)

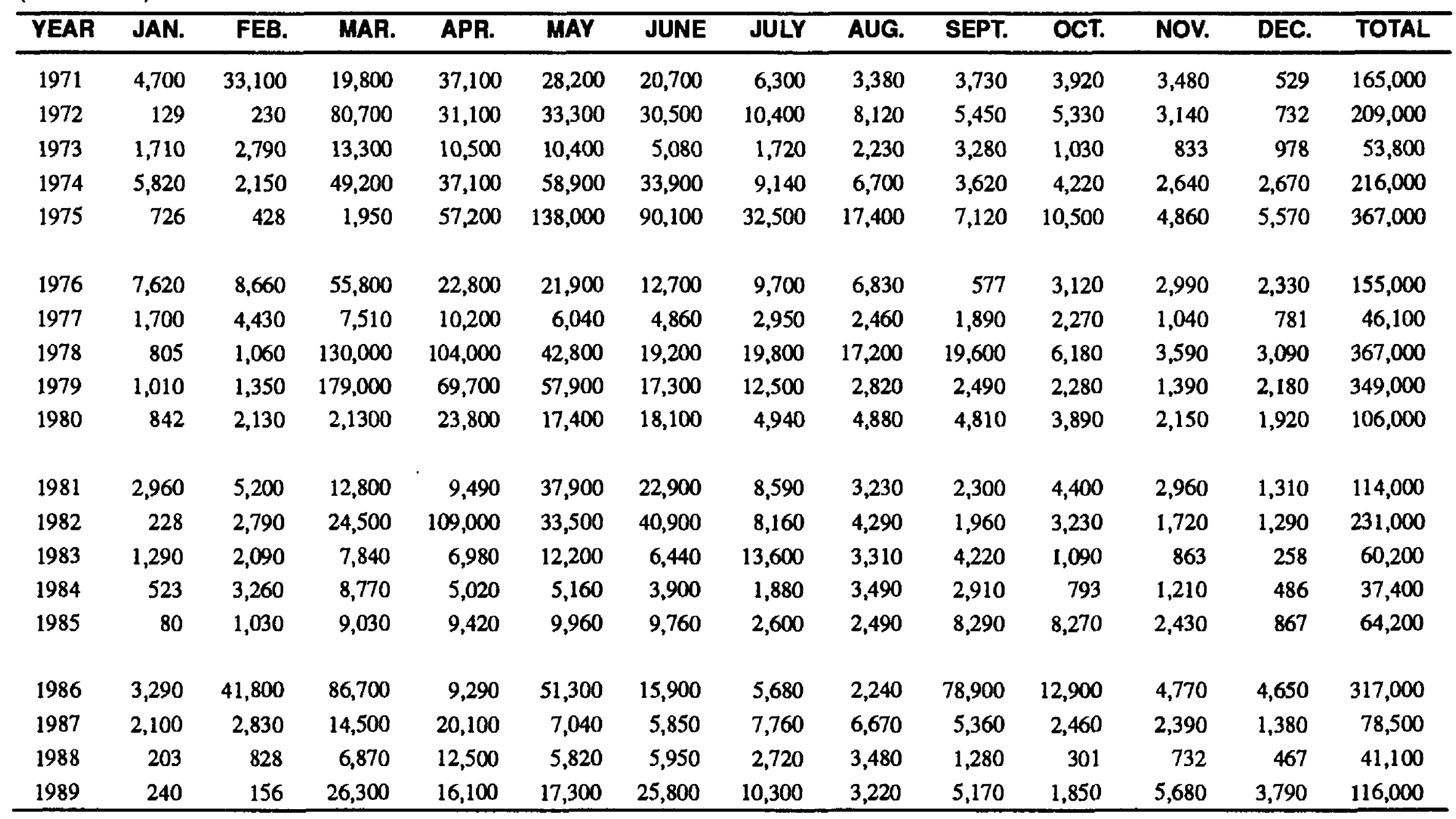


Table 11. Synthesized streamflow volumes for Milk River at Paradise diversion dam, Montana, 1928-89, in acre-feet

\begin{tabular}{|c|c|c|c|c|c|c|c|c|c|c|c|c|c|}
\hline YEAR & JAN. & FEB. & MAR. & APR. & MAY & JUNE & JULY & AUG. & SEPT. & OCT. & NOV. & DEC. & TOTAL \\
\hline 1928 & 16,100 & 6,980 & 123,000 & 85,300 & 29,600 & 30,300 & 44,600 & 10,300 & 9,400 & 8,980 & 7.120 & 3,870 & 376,000 \\
\hline 1929 & 2,600 & 2,210 & 34,600 & 44,200 & 44,200 & 40,700 & 3,540 & 74 & 1,400 & 4,140 & 4,080 & 2,880 & 185,000 \\
\hline 1930 & 1,890 & 21,700 & 73,600 & 58,100 & 26,100 & 9,700 & 3,040 & 1,440 & 4,040 & 3,530 & 2,810 & 3,420 & 209,000 \\
\hline 1931 & 2,270 & 2,500 & 10,400 & 6,660 & 4,140 & 5,840 & 2,720 & 3,760 & 3,740 & 25 & 2,770 & 873 & 45,700 \\
\hline 1932 & 1,030 & 5,840 & 22,500 & 17,900 & 15,000 & 25,400 & 3,030 & 2.120 & 2,850 & 1,770 & 2,160 & 701 & 100,000 \\
\hline 1933 & 596 & 1,230 & 20,100 & 39,100 & 30,100 & 12,400 & 996 & 105 & 101 & 3,450 & 4,890 & 1,350 & 114,000 \\
\hline 1934 & 3,390 & 16,600 & 32,500 & 23,000 & 16,500 & 23,300 & 4,800 & 1,210 & 4,760 & 3,610 & 5,670 & 3,920 & 139,000 \\
\hline 1935 & 8,530 & 17,900 & 25,900 & 50,600 & 19,200 & 8,080 & 8,120 & 1.690 & 869 & 2.400 & 83 & 184 & 144,000 \\
\hline 1936 & 74 & 23 & 23,300 & 66,800 & 7,160 & 5,350 & 744 & 2,420 & 916 & 818 & 1,980 & 209 & 110,000 \\
\hline 1937 & 178 & 167 & 6,740 & 48,800 & 19,200 & 26.700 & 8,960 & 603 & 2,250 & 4,010 & 1,090 & 560 & 119,000 \\
\hline 1938 & 996 & 1,150 & 44,300 & 32,900 & 27,800 & 21,300 & 11,700 & 2,060 & 4,000 & 1,820 & 3,650 & 781 & 152,000 \\
\hline 1939 & 560 & 355 & 83,100 & 8,200 & 6,110 & 41,300 & 6,960 & 1510 & 2,290 & 849 & 2,170 & 277 & 154,000 \\
\hline 1940 & 105 & 144 & 29,900 & 79,600 & 13,200 & 5,910 & 5,430 & 885 & 2,370 & 1.760 & 2.430 & 314 & 142,000 \\
\hline 1941 & 184 & 333 & 53,700 & 5.460 & 4,690 & 13,100 & 2,660 & 941 & 1,380 & 2,360 & 1,800 & 1,840 & 88,400 \\
\hline 1942 & 369 & 3,720 & 19,000 & 46,700 & 19,200 & 34,900 & 7.210 & 830 & 2,030 & 4,200 & 2,090 & 2,120 & 142,000 \\
\hline 1943 & 566 & 46,600 & 108,000 & 45,000 & 24,500 & 29,400 & 9,270 & 2,130 & 1,200 & 4,120 & 4,420 & 1,600 & 277,000 \\
\hline 1944 & 3,460 & 4,270 & 11,900 & 10,300 & 4,460 & 7,050 & 4,620 & 11,000 & 1,130 & 1,240 & 1,270 & 959 & 61,600 \\
\hline 1945 & 400 & 5,500 & 24,000 & 8,190 & 12,400 & 39,000 & 4,560 & 74 & 1,180 & 2,660 & 1,520 & 1,330 & 101,000 \\
\hline 1946 & 750 & 8,000 & 29,700 & 6,020 & 8,380 & 9,910 & 3,050 & 1,210 & 2,720 & 6,490 & 1,700 & 1,230 & 79,200 \\
\hline 1947 & 1,000 & 3,820 & 107,000 & 49,200 & 24,900 & 15,200 & 2,850 & 3,840 & 5,310 & 5,750 & 2,690 & 1,830 & 223,000 \\
\hline 1948 & 1,990 & 1,170 & 22,600 & 91,000 & 51,200 & 59,700 & 20,500 & 8,190 & 1,150 & 6,280 & 4,500 & 2,360 & 271,000 \\
\hline 1949 & 1,200 & 1,140 & 9,140 & 26,100 & 21,100 & 6,650 & 1,400 & 86 & 910 & 4,530 & 3,300 & 1,190 & 76,700 \\
\hline 1950 & 92 & 861 & 10,500 & 127,000 & 32.400 & 28,900 & 10,500 & 4,770 & 785 & 2,670 & 4,830 & 1,750 & 226,000 \\
\hline 1951 & 1,680 & 1,400 & 42,000 & 83,400 & 52,700 & 52,900 & 35,300 & 15,400 & 19,700 & 17,900 & 13,000 & 8,320 & 344,000 \\
\hline 1952 & 5,200 & 13,400 & 81,800 & 404,000 & 32,900 & 14,500 & 9.720 & 3,270 & 2,430 & 3,530 & 3,400 & 3,400 & 577,000 \\
\hline 1953 & 3,550 & 4,630 & 12,500 & 48,900 & 62,400 & 137,000 & 21,900 & 5,560 & 3,510 & 6.150 & 5,840 & 4,180 & 31,7000 \\
\hline 1954 & 2,710 & 11,700 & 11,400 & 91,600 & 46,400 & 26,000 & 6,540 & 6,640 & 9,040 & 7,900 & 5,020 & 3,330 & 228,000 \\
\hline 1955 & 1,300 & 1.440 & 24,800 & 132,000 & 70,800 & 26,000 & 84,900 & 1,090 & 2,210 & 5,130 & 1,940 & 2,520 & 354,000 \\
\hline 1956 & 1,890 & 2,350 & 21,500 & 32,600 & 25,500 & 13,900 & 14,900 & 7,940 & 2,800 & 4,120 & 4,550 & 1.480 & 134,000 \\
\hline 1957 & 1,150 & 2,850 & 30,000 & 35,500 & 30,700 & 15,800 & 1,600 & 1,700 & 3,530 & 6,890 & 4,920 & 2,970 & 138,000 \\
\hline 1958 & 1,900 & 3,850 & 42,800 & 78,500 & 11,800 & 12,900 & 5,190 & 824 & 1,580 & 3,620 & 3,120 & 3,530 & 170,000 \\
\hline 1959 & 2,320 & 2,380 & 71,400 & 34,300 & 28,000 & 20,200 & 5,640 & 1.690 & 3,270 & 4,890 & 3,930 & 4,970 & 183,000 \\
\hline 1960 & 2,240 & 2,900 & 107,000 & 21,000 & 28,900 & 6,410 & 873 & 1,200 & 964 & 2,540 & 2,090 & 1,820 & 178,000 \\
\hline 1961 & 2,150 & 2,780 & 29,400 & 5,340 & 16,300 & 8.410 & 461 & 504 & 1,060 & 3,380 & 2,320 & 621 & 72,700 \\
\hline 1962 & 2,400 & 4,640 & 36,400 & 23,600 & 10,600 & 7,530 & 29,600 & 172 & 2,230 & 1,480 & 1,560 & 1,430 & 122,000 \\
\hline 1963 & 633 & 17,300 & 9,510 & 4,140 & 5,300 & 7.160 & 4,820 & 928 & 1,560 & 1,680 & 762 & 486 & 54,200 \\
\hline 1964 & 492 & 1,270 & 2,770 & 16,300 & 50,800 & 48,500 & 9,220 & 2,930 & 3,810 & 6,540 & 4,360 & 1,910 & 149,000 \\
\hline 1965 & 756 & 8,130 & 21,800 & 149,000 & 41,900 & 54,200 & 23,600 & 5,530 & 10,800 & 9,090 & 5,260 & 5,130 & 335,000 \\
\hline 1966 & 769 & 1,930 & 76,400 & 28,000 & 15,700 & 29,200 & 11,900 & 4,260 & 1,920 & 6,950 & 3,530 & 2,630 & 183,000 \\
\hline 1967 & 2,830 & 5,280 & 74,000 & 89,000 & 130,000 & 50,000 & 7,830 & 3,390 & 3,310 & 5.210 & 4,580 & 3,190 & 379,000 \\
\hline 1968 & 4,990 & 8,420 & 27,900 & 14,900 & 22,700 & 18,000 & 8,080 & 7,490 & 11,600 & 13,700 & 7,530 & 4,630 & 150,000 \\
\hline 1969 & 1,600 & 2,500 & 69,700 & 118,000 & 22,800 & 23,300 & 25,100 & 2,040 & 2,110 & 5,320 & 5,020 & 3,370 & 281,000 \\
\hline 1970 & 1,060 & 2,750 & 22,800 & 21,200 & 60,600 & 33,900 & 7,180 & 4,000 & 4,750 & 4,690 & 4,620 & 1,690 & 169,000 \\
\hline
\end{tabular}


Table 11. Synthesized streamflow volumes for Milk River at Paradise diversion dam, Montana, 1928-89, in acre-feet (Continued)

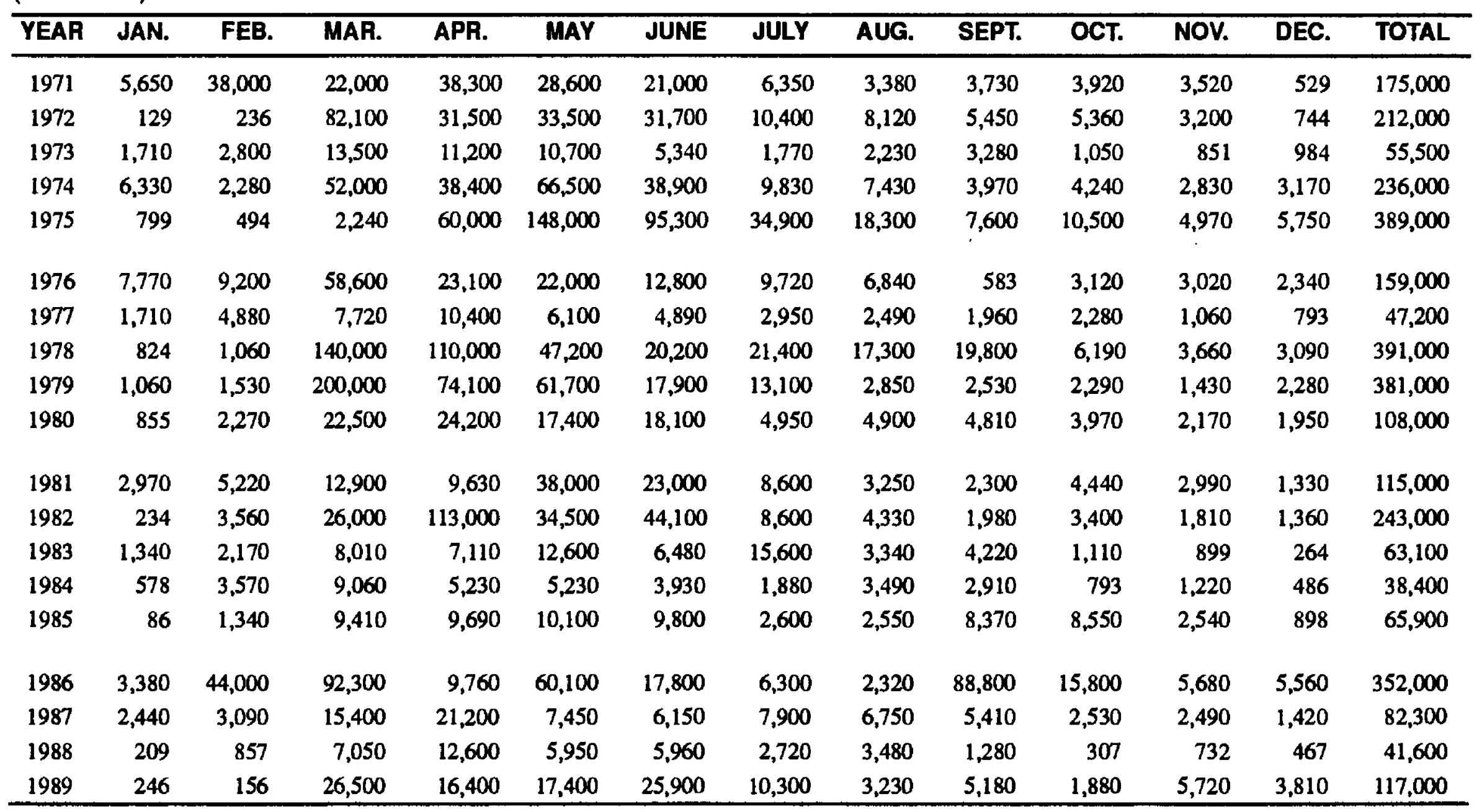


Table 12. Synthesized streamflow volumes for Milk River at Harlem pumping plant, Montana, 1928-89, in acre-feet

\begin{tabular}{|c|c|c|c|c|c|c|c|c|c|c|c|c|c|}
\hline YEAR & JAN. & FEB. & MAR. & APR. & MAY & JUNE & JULY & AUG. & SEPT. & OCT. & NOV. & DEC. & TOTAL \\
\hline 1928 & 16,100 & 6,980 & 170,000 & 145,000 & 34,600 & 36,400 & 51,600 & 12,300 & 10,300 & 10,900 & 7,130 & 4,170 & 505,000 \\
\hline 1929 & 2,610 & 2,220 & 43,600 & 69,300 & 61,000 & 46,400 & 5,100 & 92 & 1,480 & 4,830 & 4,080 & 3,090 & 244,000 \\
\hline 1930 & 1,900 & 25,100 & 115,000 & 112,000 & 29,700 & 10,900 & 4,020 & 1,530 & 4,140 & 4,350 & 2,820 & 3,680 & 315,000 \\
\hline 1931 & 2,280 & 2,510 & 13,800 & 7,920 & 4.400 & 6,450 & 3,040 & 3,780 & 3,830 & 31 & 2,770 & 904 & 51,700 \\
\hline 1932 & 1,040 & 6,480 & 33,600 & 27,700 & 17,700 & 28,000 & 3,610 & 2,120 & 2,930 & 2,280 & 2,170 & 707 & 128,000 \\
\hline 1933 & 603 & 1,240 & 29,900 & 52,000 & 37,300 & 13,800 & 2,560 & 148 & 184 & 3.460 & 4,890 & 1.410 & 147,000 \\
\hline 1934 & 3,390 & 19,400 & 53,100 & 32,000 & 16,800 & 24,500 & 4,870 & 1.210 & 4,840 & 3,620 & 5,680 & 4,060 & 173,000 \\
\hline 1935 & 8,530 & 17,900 & 44,300 & 78,800 & 23,800 & 8,820 & 10,000 & 1,700 & 952 & 2,410 & 89 & 228 & 197,000 \\
\hline 1936 & 80 & 29 & 25,700 & 116,000 & 8,650 & 5,410 & 750 & 2,420 & 994 & 824 & 1.980 & 209 & 163,000 \\
\hline 1937 & 295 & 272 & 8,390 & 62,700 & 19,400 & 29,700 & 12,900 & 603 & 2,290 & 4,020 & 1,090 & 560 & 142,000 \\
\hline 1938 & 1,110 & 1,790 & 61,500 & 41,100 & 30,500 & 27,500 & 14,700 & 2,100 & 4,180 & 1,930 & 3,860 & 885 & 191,000 \\
\hline 1939 & 726 & 478 & 146,000 & 12,200 & 7,910 & 68,900 & 10,800 & 1,510 & 2,290 & 873 & 2,210 & 394 & 254,000 \\
\hline 1940 & 172 & 265 & 40,800 & 176,000 & 21,400 & 8,200 & 5,770 & 1,610 & 2,390 & 1,800 & 2,430 & 344 & 261,000 \\
\hline 1941 & 184 & 444 & 107,000 & 9,960 & 6,500 & 21,300 & 6,070 & 1,730 & 1,450 & 2,830 & 2,300 & 1,910 & 162,000 \\
\hline 1942 & 369 & 6,120 & 28,700 & 70,700 & 25,600 & 53,400 & 11,700 & 1,990 & 2,450 & 5,010 & 2,450 & 2,250 & 211,000 \\
\hline 1943 & 609 & 92,200 & 192,000 & 75,400 & 29,800 & 34,400 & 11,100 & 2,200 & 1,200 & 4,350 & 4,610 & 1,800 & 449,000 \\
\hline 1944 & 6,160 & 7,350 & 17,600 & 16,200 & 5,640 & 10,400 & 10,000 & 15,200 & 1,180 & 1,610 & 1,520 & 1,120 & 94,100 \\
\hline 1945 & 480 & 10,300 & 41,100 & 13,000 & 17,100 & 64,000 & 6,790 & 135 & 1,340 & 2,830 & 1,670 & 1,330 & 160,000 \\
\hline 1946 & 750 & 14,600 & 50,300 & 8,770 & 10,100 & 10,600 & 3,200 & 1.480 & 2,760 & 7,290 & 1,860 & 1,380 & 113,000 \\
\hline 1947 & 1,000 & 4,040 & 142,000 & 64,000 & 27,900 & 17,000 & 2,980 & 4,370 & 5,430 & 6,510 & 2,990 & 1,930 & 280,000 \\
\hline 1948 & 2,000 & 1,710 & 35,200 & 140,000 & 66,300 & 62,200 & 20,800 & 9,270 & 1,210 & 7,120 & 5,080 & 2,360 & 353,000 \\
\hline 1949 & 1,200 & 1,350 & 10,000 & 29,400 & 26,600 & 7,840 & 1,550 & 98 & 958 & 4,700 & 3,470 & 1,250 & 88,400 \\
\hline 1950 & 123 & 1,020 & 12,800 & 204,000 & 35,200 & 29,400 & 10,500 & 5.490 & 839 & 2,800 & 5,020 & 1,820 & 309,000 \\
\hline 1951 & 2,020 & 1,840 & 51,300 & 117,000 & 74,000 & 56,200 & 36,300 & 21,300 & 21,500 & 19,300 & 13,200 & 8,680 & 423,000 \\
\hline 1952 & 5,260 & 17,500 & 105,000 & 784,000 & 49,200 & 18,100 & 13,000 & 3,760 & 2,920 & 4,020 & 3,450 & 3,400 & $1,010,000$ \\
\hline 1953 & 3,560 & 4,660 & 15,200 & 55,100 & 87,400 & 190,000 & 27,800 & 7.740 & 4,090 & 7,050 & 6,470 & 4,700 & 413,000 \\
\hline 1954 & 2,910 & 14,500 & 14,100 & 140,000 & 53,600 & 32,700 & 8,490 & 9,310 & 11,600 & 10,600 & 5,560 & 3,770 & 308,000 \\
\hline 1955 & 1.410 & 1,560 & 37,800 & 256,000 & 130,000 & 38,800 & 138,000 & 4,550 & 3,990 & 7,220 & 2,050 & 2,520 & 625,000 \\
\hline 1956 & 1,890 & 2,350 & 28,000 & 51,600 & 31,400 & 15,500 & 18,400 & 10,200 & 3,570 & 5,200 & 4,550 & 1.480 & 174,000 \\
\hline 1957 & 1,150 & 2,890 & 33,900 & 71,800 & 41,600 & 18,500 & 3.580 & 3,750 & 4,140 & 8,080 & 4,940 & 3,000 & 197,000 \\
\hline 1958 & 1,900 & 4,250 & 62,800 & 128,000 & 13,800 & 13,700 & 5,770 & 1,760 & 1,580 & 3,760 & 3,120 & 3,740 & 244,000 \\
\hline 1959 & 2,340 & 2,380 & 97,600 & 48,700 & 31,300 & 23,500 & 7,560 & 1,890 & 3.360 & 5,810 & 3,970 & 5,100 & 234,000 \\
\hline 1960 & 2,420 & 3,310 & 165,000 & 32,000 & 37,900 & 8,050 & 1,600 & 1,810 & 1,010 & 2,570 & 2,090 & 1,820 & 259,000 \\
\hline 1961 & 2,150 & 2,780 & 42,700 & 6,240 & 17,200 & 9,150 & 461 & 504 & 1,060 & 3,380 & 2,320 & 621 & 88,500 \\
\hline 1962 & 2,400 & 4,820 & 50,400 & 28,700 & 11,800 & 23,100 & 41,800 & 283 & 2,230 & 1,500 & 1,560 & 1,460 & 170,000 \\
\hline 1963 & 639 & 24,000 & 13,900 & 10,900 & 6,140 & 7,770 & 14,600 & 941 & 1,620 & 1,680 & 762 & 486 & 83,400 \\
\hline 1964 & 560 & 1,290 & 2,820 & 19,700 & 66,800 & 56,900 & 11,200 & 3,300 & 4,180 & 7,210 & 4,810 & 1,990 & 181,000 \\
\hline 1965 & 756 & 10,300 & 23,800 & 256,000 & 66,200 & 91,600 & 44,200 & 7,160 & 16,600 & 12,300 & 6,380 & 5,880 & 542,000 \\
\hline 1966 & 855 & 2,050 & 138,000 & 56,300 & $2<, 400$ & 33,400 & 13,400 & 5,200 & 2,430 & 7,700 & 3,570 & 2,710 & 288,000 \\
\hline 1967 & 2,990 & 5,780 & 104,000 & 157,000 & 215,000 & 59,400 & 14,300 & 4,540 & 5,340 & 6,630 & 5,080 & 3,520 & 583,000 \\
\hline 1968 & 7,220 & 11,100 & 38,700 & 20,800 & 25,400 & 22,600 & 9,170 & 8,440 & 12,700 & 15,100 & 7,940 & 4,830 & 184,000 \\
\hline 1969 & 1,600 & 2,510 & 84,100 & 191,000 & 28,100 & 28,600 & 32,200 & 2,610 & 2,240 & 6,270 & 5,860 & 4,160 & 389,000 \\
\hline 1970 & 1,160 & 3,340 & 29,200 & 53,200 & 107,000 & 50,300 & 11,400 & 4,940 & 5,320 & 5,970 & 5,350 & 2,100 & 279,000 \\
\hline
\end{tabular}


Table 12. Synthesized streamflow volumes for Milk River at Harlem pumping plant, Montana, 1928-89, in acre-feet (Continued)

\begin{tabular}{|c|c|c|c|c|c|c|c|c|c|c|c|c|c|}
\hline YEAR & JAN. & FEB. & MAR. & APR. & MAY & JUNE & JULY & AUG. & SEPT. & OCT. & NOV. & DEC. & TOTAL \\
\hline 1972 & 129 & 259 & 117,000 & 36,300 & 36,100 & 45,000 & 11,800 & 8,980 & 5,640 & 5,980 & 3,490 & 775 & 271,000 \\
\hline 1974 & 8,450 & 2,820 & 72,800 & 61,700 & 115,000 & 62,600 & 13,600 & 11,200 & 5,530 & 4,610 & 3,630 & 5.200 & 367,000 \\
\hline 1975 & 1,120 & 778 & 3,600 & 97,000 & 225,000 & 132,000 & 47,100 & 25,500 & 10,700 & 12,100 & 5,450 & 6,470 & 566,000 \\
\hline 1977 & 1,760 & 6,710 & 10,400 & 13,500 & 7,460 & 5,360 & 3,360 & 2,600 & 2,270 & 2,360 & 1,140 & 861 & 57,800 \\
\hline 1978 & 910 & 1,080 & 185,000 & 185,000 & 71,800 & 25,500 & 29,300 & 17,600 & 22,500 & 7,030 & 3,970 & 3,110 & 553,000 \\
\hline 1979 & 1,290 & 2,250 & 327,000 & 122,000 & 88,600 & 21,900 & 17,600 & 3,420 & 2,890 & 2,720 & 1,580 & 2,660 & 594,000 \\
\hline 1980 & 904 & 2,860 & 30,000 & 31,000 & 18,700 & 19,300 & 5,160 & 5,170 & 4,840 & 4,700 & 2,260 & 2,040 & 127,000 \\
\hline 1985 & 92 & 2,610 & 14,400 & 29,800 & 18,100 & 10,600 & 2,820 & 2,790 & 9,260 & 10,600 & 3,010 & 1,010 & 105,000 \\
\hline 1986 & 3,740 & 53,300 & 172,000 & 15,900 & 104,000 & 27,600 & 10,300 & 2,890 & 205,000 & 35,900 & 10,100 & 9,640 & 651,000 \\
\hline 1987 & 3,950 & 4,470 & 50,400 & 41,900 & 13,000 & 8,850 & 9,020 & 8,600 & 6,050 & 3,590 & 2,960 & 1,650 & 154,000 \\
\hline 1988 & 277 & 1,010 & 9,780 & 19,100 & 8,260 & 6,510 & 2,860 & 3,520 & 1,340 & 326 & 744 & 473 & 54,200 \\
\hline 1989 & 252 & 161 & 28,000 & 23,000 & 18,900 & 29,100 & 10,900 & 3,370 & 5,360 & 2,300 & 5,910 & 3,940 & 131,000 \\
\hline
\end{tabular}


Table 13. Synthesized streamflow volumes for Milk River near Harlem, Montana, 1928-1989, in acrefeet

\begin{tabular}{|c|c|c|c|c|c|c|c|c|c|c|c|c|c|}
\hline$\overline{\text { YEAR }}$ & JAN. & FEB. & MAR. & APR. & MAY & JUNE & JULY & AUG. & SEPT. & OCT. & NOV. & DEC. & TOTAL \\
\hline 1928 & 16,200 & 6,990 & 175,000 & 148,000 & 35,000 & 37,500 & 52,500 & 12,600 & 10,400 & 11,100 & 7.130 & 4,300 & 517,000 \\
\hline 1929 & 2,610 & 2,220 & 46,900 & 70,300 & 62,900 & 47,400 & 5,410 & 98 & 1,520 & 4,890 & 4,080 & 3,190 & 251,000 \\
\hline 1930 & 1,900 & 25,100 & 114,000 & 117,000 & 29,700 & 11,100 & 4,210 & 1,560 & 4,180 & 4,430 & 2,820 & 3,790 & 320,000 \\
\hline 1931 & 2,280 & 2,510 & 14,800 & 7,940 & 4,400 & 6.470 & 3,040 & 3,780 & 3,860 & 31 & 2,770 & 916 & 52,800 \\
\hline 1932 & 1,050 & 6,480 & 35,800 & 28,100 & 17,800 & 28,300 & 3,730 & 2,120 & 2,970 & 2,320 & 2,170 & 707 & 131,000 \\
\hline 1933 & 603 & 1,240 & 31,600 & 52,500 & 37,900 & 14,000 & 2,750 & 148 & 220 & 3,460 & 4,890 & 1,440 & 151,000 \\
\hline 1934 & 3,390 & 19,400 & 55,100 & 32,400 & 16,800 & 24,700 & 4,890 & 1.210 & 4,880 & 3,620 & 5,680 & 4,130 & 176,000 \\
\hline 1935 & 8,530 & 17,900 & 45,300 & 79,700 & 23,800 & 9,020 & 10,000 & 1,700 & 988 & 2,410 & 95 & 246 & 200,000 \\
\hline 1936 & 80 & 29 & 26,800 & 117,000 & 8,700 & 5,440 & 750 & 2,420 & 1,030 & 824 & 1,980 & 209 & 166,000 \\
\hline 1937 & 344 & 317 & 8,680 & 63,200 & 19,400 & 31,100 & 14,600 & 603 & 2,290 & 4,020 & 1,090 & 560 & 146,000 \\
\hline 1938 & 1,170 & 2,080 & 62,100 & 41,600 & 30,800 & 29,400 & 15,200 & 2,120 & 4,270 & 1,980 & 3,960 & 928 & 196,000 \\
\hline 1939 & 799 & 533 & 148,000 & 12,300 & 8.410 & 78,900 & 12,200 & 1,510 & 2,290 & 879 & 2,230 & 443 & 268,000 \\
\hline 1940 & 203 & 322 & 45,800 & 178,000 & 22,000 & 8,460 & 5,830 & 1,610 & 2,390 & 1,800 & 2,430 & 357 & 269,000 \\
\hline 1941 & 184 & 494 & 110,000 & 10,200 & 6,710 & 24,000 & 6,150 & 1,770 & 1,450 & 2,990 & 2,530 & 1,940 & 168,000 \\
\hline 1942 & 369 & 7,210 & 31,100 & 76,500 & 27,500 & 54,100 & 11,800 & 2,050 & 2,460 & 5,170 & 2,610 & 2,310 & 223,000 \\
\hline 1943 & 627 & 195,000 & 113,000 & 76,400 & 31,300 & 36,200 & 11,900 & 2,230 & 1,200 & 4,460 & 4,710 & 1,890 & 478,000 \\
\hline 1944 & 7,380 & 8,750 & 18,100 & 16,800 & 5,920 & 11,900 & 10,700 & 15,300 & 1,200 & 1,760 & 1,630 & 1,190 & 101,000 \\
\hline 1945 & 510 & 12,600 & 41,800 & 14,500 & 18,900 & 75,300 & 7,810 & 160 & 1,420 & 2,910 & 1,740 & 1,330 & 179,000 \\
\hline 1946 & 750 & 17,600 & 51,100 & 8,930 & 10,800 & 10,800 & 3,270 & 1,600 & 2,780 & 7,630 & 1,930 & 1,450 & 119,000 \\
\hline 1947 & 1,000 & 4,150 & 150,000 & 65,900 & 28,500 & 17,800 & 3,030 & 4,430 & 5,480 & 6,840 & 3,120 & 1,970 & 292,000 \\
\hline 1948 & 2,000 & 1,960 & 40,800 & 151,000 & 71,100 & 63,200 & 21,000 & 9,700 & 1,230 & 7,510 & 5,340 & 2,360 & 377,000 \\
\hline 1949 & 1,200 & 1,440 & 10,300 & 30,300 & 29,100 & 8,380 & 1,620 & 98 & 976 & 4,780 & 3,550 & 1,290 & 93,100 \\
\hline 1950 & 141 & 1,090 & 13,800 & 208,000 & 35,700 & 29,600 & 10,500 & 5,720 & 857 & 2,850 & 5,110 & 1,850 & 315,000 \\
\hline 1951 & 2,170 & 2,040 & 55,600 & 119,000 & 74,500 & 56,300 & 36,400 & 21,300 & 21,500 & 19,300 & 13,200 & 8,850 & 430,000 \\
\hline 1952 & 5,290 & 19,400 & 797,000 & 115,000 & 49,900 & 18,600 & 13,300 & 3,800 & 2,930 & 4,060 & 3,470 & 3,400 & $1,036,000$ \\
\hline 1953 & 3,560 & 4,680 & 15,700 & 55,200 & 91,400 & 198,000 & 29,300 & 8,010 & 4,110 & 7,110 & 6,760 & 4,940 & 429,000 \\
\hline 1954 & 3,010 & 15,800 & 14,800 & 143,000 & 54,400 & 33,400 & 8,750 & 9,360 & 11,800 & 10,800 & 5,810 & 3,970 & 315,000 \\
\hline 1955 & 1,470 & 1,620 & 40,000 & 265,000 & 137,000 & 40,800 & 139,000 & 4,670 & 4,020 & 7,260 & 2,100 & 2,520 & 645,000 \\
\hline 1956 & 1,890 & 2,350 & 28,800 & 52,300 & 31,600 & 15,600 & 18,400 & 10,200 & 3,570 & 5,210 & 4,550 & 1,480 & 176,000 \\
\hline 1957 & 1,150 & 2,900 & 34,800 & 72,500 & 42,100 & 18,700 & 3,590 & 3,750 & 4,160 & 8,080 & 4,940 & 3,010 & 200,000 \\
\hline 1958 & 1,900 & 4,440 & 63,700 & 128,000 & 13,800 & 13,700 & 5,770 & 1,760 & 1,580 & 3,760 & 3,120 & 3,850 & 245,000 \\
\hline 1959 & 2,360 & 2,380 & 102,000 & 49,300 & 31,500 & 23,800 & 7,700 & 1,890 & 3,400 & 5,880 & 3,990 & 5,150 & 239,000 \\
\hline 1960 & 2,510 & 3,490 & 169,000 & 32,700 & 38,500 & 8,400 & 1,770 & 1,840 & 1,020 & 2,580 & 2,100 & 1,820 & 266,000 \\
\hline 1961 & 2,150 & 2,780 & 42,700 & 6,270 & 17,400 & 9,250 & 461 & 504 & 1,060 & 3,380 & 2,320 & 621 & 88,900 \\
\hline 1962 & 2,400 & 4,890 & 51,300 & 28,800 & 12,200 & 23,400 & 42,100 & 295 & 2.230 & 1,500 & 1,560 & 1,470 & 172,000 \\
\hline 1963 & 646 & 27,000 & 14,400 & 11,200 & 6,270 & 7,850 & 14,700 & 947 & 1,650 & 1,680 & 762 & 486 & 87,500 \\
\hline 1964 & 590 & 1,300 & 2,830 & 19,900 & 69,300 & 59,200 & 11,600 & 3,430 & 4,330 & 7,430 & 5,020 & 2,030 & 187,000 \\
\hline 1965 & 756 & 11,400 & 24,700 & 270,000 & 71,200 & 95,100 & 47,700 & 7,860 & 17,600 & 13,000 & 6,890 & 6,220 & 573,000 \\
\hline 1966 & 892 & 2,100 & 146,000 & 57,500 & 22,800 & 33,600 & 13,500 & 5,240 & 2,430 & 7,700 & 3,590 & 2,740 & 298,000 \\
\hline 1967 & 3,070 & 6,000 & 113,000 & 159,000 & 218,000 & 60,600 & 14,600 & 4,640 & 6,070 & 6,940 & 5,310 & 3,680 & 601,000 \\
\hline 1968 & 8,230 & 12,300 & 40,100 & 21,400 & 25,600 & 23,300 & 9,290 & 8,690 & 12,900 & 15,300 & 8,130 & 4,920 & 190,000 \\
\hline 1969 & 1,610 & 2,510 & 89,600 & 194,000 & 29,400 & 30,800 & 35,100 & 2,830 & 2,280 & 6,580 & 6,250 & 4,530 & 406,000 \\
\hline 1970 & 1,210 & 3,620 & 31,500 & 54,700 & 120,000 & 55,800 & 12,300 & 5,170 & 5,500 & 6,360 & 5,690 & 2,280 & 304,000 \\
\hline
\end{tabular}


Table 13. Synthesized streamflow volumes for Milk River near Harlem, Montana, 1928-1989, in acre-feet (Continued)

\begin{tabular}{|c|c|c|c|c|c|c|c|c|c|c|c|c|c|}
\hline YEAR & JAN. & FEB. & MAR. & APR. & $\overline{\text { MAY }}$ & JUNE & JULY & AUG. & SEPT. & OCT. & NOV. & DEC. & TOTAL \\
\hline 1971 & 11,300 & 67,500 & 35,400 & 75,500 & 36,400 & 25,900 & 7,320 & 3,470 & 3,850 & 4,430 & 3,760 & 541 & 275,000 \\
\hline 1972 & 129 & 270 & 119,000 & 36,900 & 36,400 & 47,300 & 11,900 & 8,980 & 5,640 & 6,010 & 3,610 & 787 & 277,000 \\
\hline 1973 & 1,720 & 2,890 & 19,400 & 18,400 & 15,100 & 8,780 & 2,180 & 2,320 & 3,340 & 1,220 & 952 & 1,000 & 77,200 \\
\hline 1974 & 9,410 & 3,070 & 74,200 & 62,600 & 127,000 & 71,800 & 14,900 & 12,500 & 6,190 & 4,630 & 4,000 & 6,120 & 397,000 \\
\hline 1975 & 1,260 & 905 & 4,130 & 243,000 & 141,000 & 101,000 & 51,500 & 27,000 & 11,600 & 12,200 & 5,670 & 6,800 & 605,000 \\
\hline 1976 & 8,610 & 235,000 & 12,500 & 107,000 & 40,000 & 23,400 & 16,400 & 10,200 & 7,350 & 643 & 3,580 & 3,140 & 2,390 \\
\hline 1977 & 1,780 & 7,540 & 10,800 & 13,900 & 7,580 & 5,420 & 3,370 & 2,650 & 2,400 & 2,370 & 1,170 & 892 & 59,900 \\
\hline 1978 & 947 & 1,080 & 204,000 & 188,000 & 80,000 & 27,400 & 32,400 & 17,700 & 22,900 & 7,050 & 4,110 & 3,120 & 589,000 \\
\hline 1979 & 1,380 & 2,580 & 364,000 & 129,000 & 95,700 & 22,800 & 17,900 & 3,470 & 2,960 & 2,730 & 1,640 & 2,830 & 647,000 \\
\hline 1980 & 922 & 3,130 & 31,600 & 31,700 & 18,700 & 19,300 & 5,170 & 5,200 & 4,850 & 4,850 & 2,280 & 2,080 & 130,000 \\
\hline 1981 & 3,010 & 5,270 & 15,500 & 11,200 & 40,500 & 26,000 & 9,280 & 3,400 & 2,340 & 4,650 & 3,110 & 1,430 & 126,000 \\
\hline 1982 & 240 & 8,160 & 35,500 & 168,000 & 50,200 & 79,300 & 13,200 & 4,950 & 2,370 & 5,430 & 2,420 & 1,800 & 371,000 \\
\hline 1983 & 1,660 & 2,620 & 12,900 & 11,000 & 21,800 & 6,860 & 30,300 & 3,870 & 4,250 & 1,860 & 1,100 & 301 & 98,500 \\
\hline 1984 & 916 & 5,460 & 12,900 & 8,810 & 5,970 & 4,570 & 1,910 & 3,490 & 2,910 & 799 & 1,230 & 504 & 49,400 \\
\hline 1985 & 92 & 3,190 & 15,100 & 30,300 & 18,200 & 10,700 & 2,820 & 2,880 & 9,410 & 11,100 & 3,210 & 1,060 & 108,000 \\
\hline 1986 & 3,900 & 57,500 & 176,000 & 16,800 & 120,000 & 31,100 & 11,500 & 3,040 & 218,000 & 41,300 & 11,800 & 11,300 & 702,000 \\
\hline 1987 & 4,580 & 4,960 & 51,600 & 44,000 & 13,700 & 9,380 & 9,280 & 8,750 & 6,150 & 3,730 & 3,150 & 1,720 & 161,000 \\
\hline 1988 & 289 & 1,060 & 10,100 & 19,200 & 8,500 & 6,520 & 2,860 & 3,520 & 1,340 & 332 & 744 & 473 & 55,000 \\
\hline 1989 & 252 & 161 & 28,400 & 23,600 & 19,100 & 29,300 & 11,000 & 3,390 & 5,370 & 2,350 & 5,970 & 3,970 & 133,000 \\
\hline
\end{tabular}


Table 14. Synthesized streamflow volumes for Milk River upstream from Peoples Creek, Montana, 1928-89, in acre-feet

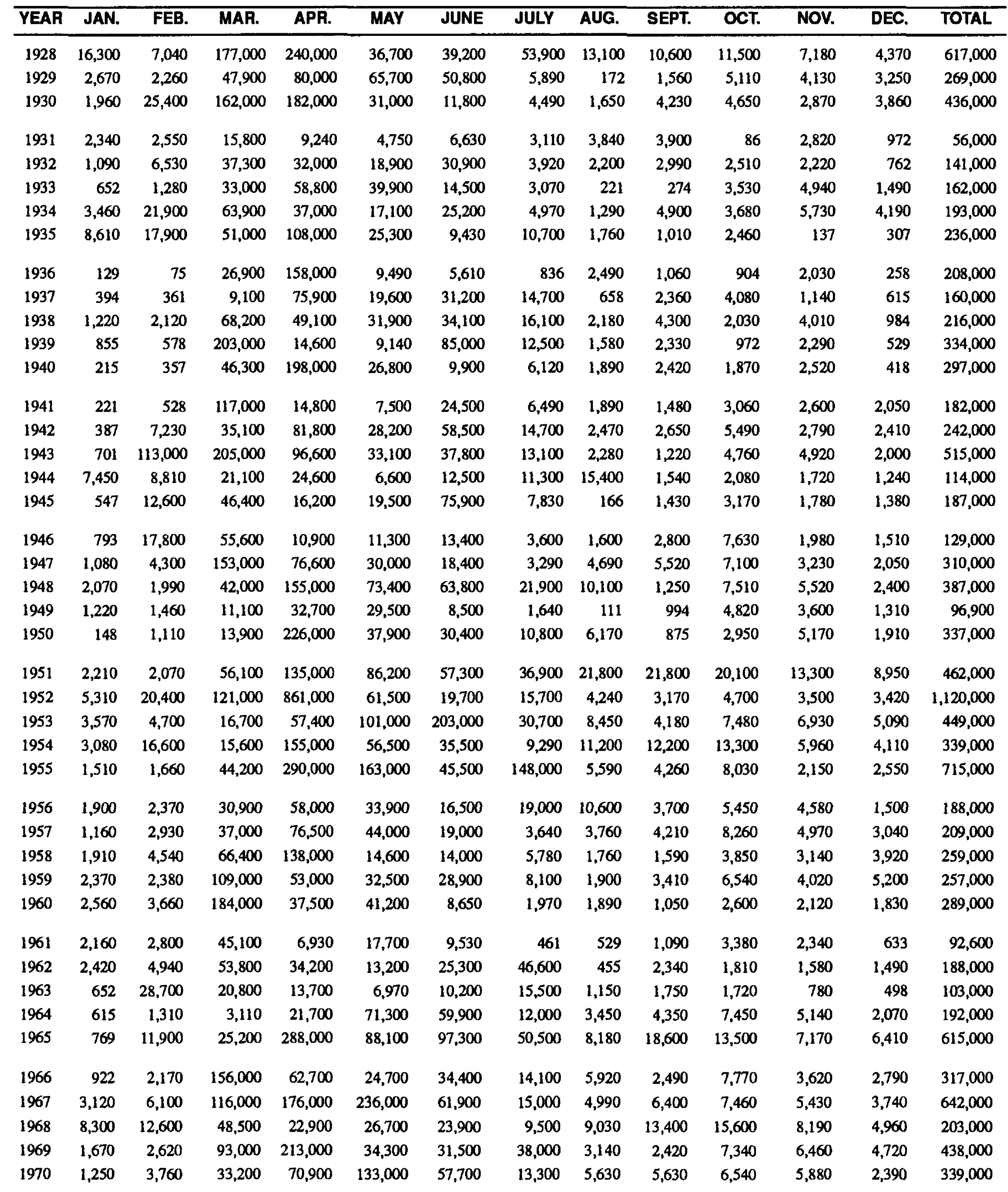


Table 14. Synthesized streamflow volumes for Milk River upstream from Peoples Creek, Montana, 1928-89, in acre-feet (Continued)

\begin{tabular}{|c|c|c|c|c|c|c|c|c|c|c|c|c|c|}
\hline YEAR & JAN. & FEB. & MAR. & APR. & MAY & JUNE & JULY & AUG. & SEPT. & OCT. & NOV. & DEC. & TOTAL \\
\hline 1972 & 135 & 288 & 127,000 & 38,300 & 37,700 & 48,600 & 12,200 & 9,210 & 5,850 & 6,470 & 3,700 & 805 & 290,000 \\
\hline 1974 & 9,970 & 3,430 & 76,800 & 77,400 & 136,000 & 73,200 & 15,700 & 13,200 & 6,400 & 5,000 & 4,210 & 6,270 & 428,000 \\
\hline 1975 & 1,360 & 955 & 4,350 & 110,000 & 261,000 & 142,000 & 52,900 & 27,800 & 12,200 & 13,500 & 5,800 & 7,050 & 639,000 \\
\hline 1978 & 1,040 & 1,170 & 220,000 & 202,000 & 86,100 & 28,100 & 34,400 & 17,900 & 23,800 & 7,240 & 4,400 & 3,340 & 629,000 \\
\hline 1979 & 1,520 & 2,720 & 374,000 & 147,000 & 107,000 & 23,700 & 19,500 & 3,810 & 3,060 & 2,850 & 1,840 & 3,070 & 690,000 \\
\hline 1980 & 1,010 & 3,200 & 33,400 & 35,700 & 19,200 & 19,700 & 5,290 & 5,370 & 4,960 & 4,990 & 2,470 & 2,160 & 138,000 \\
\hline 1981 & 3,140 & 15,200 & 16,600 & 11,600 & 41,100 & 26,700 & 9,640 & 3,430 & 2,350 & 4,650 & 3,210 & 1,510 & 139,000 \\
\hline 1985 & 117 & 3,480 & 16,200 & 35,000 & 19,100 & 11,000 & 2,830 & 2,910 & 9,470 & 11,500 & 3,380 & 1,130 & 116,000 \\
\hline 1986 & 4,020 & 59,700 & 196,000 & 17,900 & 130,000 & 32,000 & 12,400 & 3,170 & 229,000 & 45,400 & 12,800 & 12,300 & 755,000 \\
\hline 1987 & 4,970 & 6,540 & 59,500 & 49,400 & 14,400 & 9,930 & 10,200 & 9,210 & 6,280 & 3,830 & 3,360 & 1,850 & 179,000 \\
\hline 1988 & 320 & 1,110 & 10,700 & 20,300 & 8,940 & 6,780 & 3,430 & 3,530 & 1,340 & 332 & 797 & 529 & 58,100 \\
\hline 1989 & 289 & 194 & 30,700 & 26,000 & 20,100 & 30,300 & 11,100 & 3,420 & 5,410 & 2,360 & 6,130 & 4,070 & 140,000 \\
\hline
\end{tabular}


Table 15. Synthesized streamflow volumes for Peoples Creek at mouth, Montana, 1928-89, in acre-feet

\begin{tabular}{|c|c|c|c|c|c|c|c|c|c|c|c|c|c|}
\hline YEAR & JAN. & FEB. & MAR. & APR. & MAY & JUNE & JULY & AUG. & SEPT. & OCT. & NOV. & DEC. & TOTAL \\
\hline 1928 & 6.1 & 5.8 & 10,600 & 7.380 & 738 & 2,440 & 1,840 & 799 & 77 & 400 & 6.0 & 301 & 24,600 \\
\hline 1929 & 6.1 & 5.6 & 7,320 & 2,260 & 4,180 & 2,080 & 676 & 18 & 77 & 148 & 6.0 & 215 & 17,000 \\
\hline 1930 & 6.1 & 5.6 & 6,390 & 4.640 & 68 & 399 & 424 & 55 & 77 & 178 & 6.0 & 258 & 12,500 \\
\hline 1931 & 6.1 & 5.6 & 2,340 & 48 & 0 & 60 & 6.1 & 6.1 & 77 & 0 & 6.0 & 31 & 2,580 \\
\hline 1932 & 6.1 & 5.8 & 4,800 & 774 & 166 & 595 & 283 & 6.1 & 77 & 105 & 6.0 & 6.1 & 6.830 \\
\hline 1933 & 6.1 & 5.6 & 3,690 & 1.070 & 1,480 & 571 & 443 & 6.1 & 77 & 0 & 6.0 & 61 & 7.410 \\
\hline 1934 & 6.1 & 5.6 & 4,490 & 714 & 0 & 565 & 49 & 6.1 & 77 & 0 & 6.0 & 141 & 6,060 \\
\hline 1935 & 6.1 & 5.6 & 2,150 & 2,080 & 166 & 446 & 6.1 & 6.1 & 77 & 0 & 6.0 & 43 & 5,000 \\
\hline 1936 & 6.1 & 5.8 & 2,400 & 3,510 & 123 & 60 & 6.1 & 6.1 & 77 & 0 & 0 & 0 & 6,190 \\
\hline 1937 & 117 & 106 & 676 & 1,250 & 123 & 3,030 & 3,940 & 0 & 0 & 0 & 0 & 0 & 9,240 \\
\hline 1938 & 117 & 666 & 1,230 & 1,010 & 861 & 4,280 & 1,050 & 43 & 184 & 111 & 220 & 105 & 9,880 \\
\hline 1939 & 166 & 122 & 4.730 & 113 & 1,110 & 22.300 & 3,070 & 0 & 0 & 12 & 42 & 117 & 31,700 \\
\hline 1940 & 68 & 127 & 10.900 & 4,520 & 1,410 & 583 & 117 & 0 & 0 & 0 & 0 & 31 & 17,800 \\
\hline 1941 & 0 & 111 & 6,520 & 655 & 461 & 6,070 & 178 & 92 & 0 & 350 & 512 & 74 & 15,000 \\
\hline 1942 & 0 & 2,440 & 5,350 & 12,900 & 4,120 & 1,430 & 191 & 141 & 24 & 350 & 357 & 135 & 27,500 \\
\hline 1943 & 43 & 46,000 & 6,520 & 2,140 & 3,380 & 4,050 & 1,720 & 74 & 0 & 240 & 202 & 203 & 64,600 \\
\hline 1944 & 2,710 & 3,110 & 984 & 1,310 & 615 & 3,150 & 1,480 & 49 & 48 & 320 & 250 & 160 & 14,200 \\
\hline 1945 & 80 & 4.890 & 1,600 & 3.390 & 4,120 & 25,100 & 2,280 & 61 & 167 & 178 & 155 & 0 & 42,000 \\
\hline 1946 & 0 & 6,660 & 1.910 & 351 & 1,480 & 298 & 154 & 271 & 42 & 738 & 161 & 154 & 12,200 \\
\hline 1947 & 0 & 233 & 19,300 & 4,280 & 1,230 & 1,610 & 129 & 129 & 119 & 738 & 303 & 105 & 28,200 \\
\hline 1948 & 12 & 546 & 12,500 & 24,500 & 10,600 & 2,140 & 307 & 922 & 60 & 861 & 577 & 0 & 53,100 \\
\hline 1949 & 0 & 205 & 738 & 2,140 & 5,530 & 1,190 & 154 & 12 & 48 & 172 & 179 & 68 & 10,400 \\
\hline 1950 & 31 & 161 & 2.280 & 8,330 & 1.230 & 387 & 0 & 504 & 36 & 111 & 190 & 68 & 13,300 \\
\hline 1951 & 3.38 & 444 & 9.470 & 4,280 & 1,050 & 101 & 184 & 18 & 113 & 92 & 143 & 369 & 16,600 \\
\hline 1952 & 61 & 4,140 & 23,000 & 27,400 & 1,720 & 1,070 & 676 & 80 & 12 & 86 & 48 & 0 & 58,300 \\
\hline 1953 & 6.1 & 33 & 1,110 & 214 & 8,790 & 19,800 & 3,260 & 615 & 42 & 141 & 655 & 523 & 35,100 \\
\hline 1954 & 209 & 2,830 & 1,410 & 5,710 & 1,780 & 1,550 & 578 & 129 & 381 & 486 & 547 & 449 & 16,100 \\
\hline 1955 & 117 & 117 & 4,800 & 18,600 & 15,200 & 4,460 & 2,340 & 258 & 54 & 86 & 113 & 0 & 46,200 \\
\hline 1956 & 0 & 0 & 1.720 & 1,490 & 467 & 125 & 129 & 12 & 6.0 & 25 & 0 & 0 & 3,970 \\
\hline 1957 & 0 & 39 & 2,0130 & 1,490 & 922 & 327 & 18 & 0 & 42 & 6.1 & 18 & 31 & 4,920 \\
\hline 1958 & 0 & 411 & 2,030 & 470 & 18 & 0 & 0 & 0 & 0 & 0 & 0 & 221 & 3,150 \\
\hline 1959 & 18 & 0 & 9.530 & 1,430 & 394 & 774 & 307 & 0 & 95 & 148 & 48 & 123 & 12,900 \\
\hline 1960 & 191 & 408 & 9,470 & 1,550 & 1,230 & 774 & 387 & 68 & 42 & 25 & 6.0 & 0 & 14,100 \\
\hline 1961 & 0 & 0 & 141 & 71 & 406 & 202 & 0 & 0 & 0 & 0 & 0 & 0 & 821 \\
\hline 1962 & 0 & 172 & 1,970 & 36 & 799 & 506 & 738 & 31 & 0 & 0 & 0 & 31 & 4,280 \\
\hline 1963 & 6.1 & 6.720 & 1,110 & 506 & 283 & 167 & 184 & 12 & 60 & 0 & 0 & 0 & 9,040 \\
\hline 1964 & 68 & 17 & 49 & 262 & 5,470 & 5,120 & 799 & 283 & 321 & 492 & 458 & 80 & 13,400 \\
\hline 1965 & 0 & 2,220 & 2.030 & 31,000 & 11,100 & 7,910 & 7,690 & 1,600 & 2,380 & 1,480 & 1,130 & 738 & 69,300 \\
\hline 1966 & 86 & 122 & 15,900 & 2,620 & 799 & 327 & 160 & 105 & 0 & 0 & 36 & 80 & 20,300 \\
\hline 1967 & 166 & 500 & 19,400 & 5,890 & 6,390 & 2,680 & 615 & 221 & 1,610 & 676 & 512 & 338 & 39,000 \\
\hline 1968 & 2,280 & 2,760 & 3.010 & 1,370 & 510 & 1,670 & 271 & 547 & 411 & 492 & 422 & 203 & 13,900 \\
\hline 1969 & 6.1 & 5.6 & 12,200 & 6,780 & 3,070 & 4,700 & 6,460 & 480 & 95 & 676 & 833 & 799 & 36,100 \\
\hline 1970 & 111 & 611 & 5,170 & 3,330 & 28,500 & 12,200 & 2,090 & 498 & 417 & 861 & 774 & 412 & 54,900 \\
\hline 1971 & 3,940 & 20,500 & 8,790 & 5,000 & 1,600 & 893 & 178 & 0 & 0 & 0 & 167 & 6.1 & 41,100 \\
\hline 1972 & 0 & 23 & 4,490 & 1,370 & 676 & 5,180 & 234 & 0 & 0 & 86 & 286 & 31 & 12,400 \\
\hline 1973 & 6.1 & 56 & 1,050 & 2,920 & 1,600 & 1,070 & 197 & 0 & 18 & 61 & 71 & 12 & 7,050 \\
\hline 1974 & 2.150 & 544 & 3,200 & 2,020 & 27,800 & 20,600 & 2.830 & 3,010 & 1,490 & 31 & 833 & 2,030 & 66,500 \\
\hline 1975 & 320 & 283 & 1,170 & 8,630 & 38,700 & 20,500 & 9,720 & 3,380 & 2,020 & 105 & 482 & 738 & 86,000 \\
\hline
\end{tabular}


Table 15. Synthesized streamflow volumes for Peoples Creek at mouth, Montana, 1928-89, in acre-feet (Continued)

\begin{tabular}{|c|c|c|c|c|c|c|c|c|c|c|c|c|c|}
\hline YEAR & JAN. & FEB. & MAR. & APR. & MAY & JUNE & JULY & AUG. & SEPT. & OCT. & NOV. & DEC. & TOTAL \\
\hline 1976 & 584 & 2,300 & 4.180 & 1,130 & 240 & 238 & 61 & 80 & 30 & 18 & 89 & 37 & 8,990 \\
\hline 1977 & 49 & 1,830 & 861 & 952 & 252 & 143 & 25 & 111 & 274 & 43 & 77 & 68 & 4,690 \\
\hline 1978 & 86 & 17 & 41.900 & 7,560 & 18,100 & 4,170 & 6,760 & 240 & 952 & 37 & 309 & 18 & 80,200 \\
\hline 1980 & 49 & 575 & 3,690 & 1,550 & 141 & 0 & 18 & 61 & 24 & 301 & 71 & 86 & 6,560 \\
\hline 1981 & 18 & 28 & 258 & 565 & 258 & 417 & 31 & 55 & 24 & 141 & 83 & 68 & 1,950 \\
\hline 1984 & 228 & 1,320 & 1,170 & 833 & 320 & 95 & 0 & 0 & 0 & 0 & 0 & 6.1 & 3,970 \\
\hline 1985 & 0 & 1,280 & 1,600 & 1,130 & 381 & 137 & 0 & 215 & 315 & 1,170 & 458 & 105 & 6,790 \\
\hline 1986 & 357 & 9,330 & 7,130 & 1,960 & 35,400 & 7,740 & 2,520 & 326 & 28,600 & 12,000 & 3,810 & 3,810 & 113,000 \\
\hline 1987 & 1,410 & 1,110 & 2,580 & 4,520 & 1,660 & 1,190 & 578 & 332 & 220 & 301 & 422 & 172 & 14,500 \\
\hline 1988 & 18 & 109 & 738 & 411 & 547 & 6.0 & 0 & 0 & 0 & 6.1 & 0 & 0 & 1,840 \\
\hline
\end{tabular}


Table 16. Synthesized streamflow volumes for Milk River at Vandalia diversion dam, Montana, 1928-89, in acre-feet

\begin{tabular}{|c|c|c|c|c|c|c|c|c|c|c|c|c|c|}
\hline YEAR & $\overline{J A N}$. & FEB. & MAR. & APR. & MAY & JUNE & JULY & AUG. & SEPT. & OCT. & NOV. & DEC. & TOTAL \\
\hline 1928 & 17,800 & 7,850 & 228,000 & $1,620,000$ & 64,100 & 67,000 & 77,200 & 20,900 & 14,500 & 18,000 & 8,040 & 5,710 & $2,150,000$ \\
\hline 1929 & 3,590 & 2.950 & 69,900 & 228,000 & 112,000 & 105,000 & 13,800 & 1,330 & 2.340 & 8,530 & 4,890 & 4,480 & 557,000 \\
\hline 1930 & 2,850 & 30,000 & 837,000 & $1,210,000$ & 50,900 & 22,700 & 9,200 & 3,050 & 5,160 & 8,160 & 3,610 & 5,130 & $2,190,000$ \\
\hline 1931 & 3,250 & 3,240 & 32,400 & 28,800 & 10,100 & 9,090 & 4,090 & 4,750 & 4,520 & 965 & 3,560 & 1,880 & 107,000 \\
\hline 1932 & 1,950 & 7,310 & 64,100 & 91,800 & 36,200 & 70,200 & 6,950 & 3,300 & 3,430 & 5,460 & 2,950 & 1,610 & 295,000 \\
\hline 1933 & 1,460 & 1,970 & 58,100 & 155,000 & 70,400 & 22,400 & 8,300 & 1,340 & 1,140 & 4,650 & 5,720 & 2,460 & 333,000 \\
\hline 1934 & 4,410 & 58,800 & 200,000 & 107,000 & 22,700 & 33,000 & 6,310 & 2,510 & 5,300 & 4,660 & 6,540 & 5,280 & 457,000 \\
\hline 1935 & 9.760 & 19,000 & 139,000 & 531,000 & 48,100 & 15,900 & 21,000 & 2,790 & 1,400 & 3,250 & 875 & 1,240 & 794,000 \\
\hline 1936 & 941 & 788 & 31,000 & 768,000 & 21,500 & 8,060 & 2,120 & 3,470 & 1,610 & 2,070 & 2,760 & 1,010 & 844,000 \\
\hline 1937 & 1,270 & 1,150 & 16,100 & 267,000 & 22,700 & 36,200 & 20,500 & 1,550 & 3,390 & 4,960 & 1,870 & 1,460 & 378,000 \\
\hline 1938 & 2,180 & 3,450 & 161,000 & 164,000 & 47,900 & 109,000 & 32,000 & 3,050 & 4,990 & 2,930 & 4,960 & 1,980 & 537,000 \\
\hline 1939 & 1,840 & 1,380 & $1,040,000$ & 49,100 & 21,300 & 199,000 & 21,200 & 2,660 & 2,840 & 2,340 & 3,220 & 1.920 & $1,350,000$ \\
\hline 1940 & 480 & 1,010 & 65,400 & 507,000 & 101,000 & 32,200 & 10,500 & 6,070 & 2,890 & 2,890 & 3,830 & 1,330 & 735,000 \\
\hline 1941 & 799 & 1,080 & 227,000 & 84,400 & 19,800 & 38,000 & 11,800 & 3,790 & 1,850 & 4,490 & 4,060 & 3,740 & 400,000 \\
\hline 1942 & 713 & 10,100 & 101,000 & 175,000 & 43,700 & 126,000 & 58,300 & 9,000 & 5,680 & 10,800 & 5,890 & 4,030 & 551,000 \\
\hline 1943 & 1,860 & 160,000 & 376,000 & 404,000 & 63,600 & 65,500 & 32,700 & 2,970 & 1,450 & 9,400 & 8,290 & 3,900 & $1,130,000$ \\
\hline 1944 & 11,200 & 12,800 & 67,700 & 144,000 & 17,500 & 25,200 & 21,400 & 17,700 & 6,720 & 7,350 & 3,290 & 2,120 & 337,000 \\
\hline 1945 & 1,150 & 18,900 & 117,000 & 44,000 & 33,100 & 111,000 & 10,300 & 314 & 1,830 & 7,250 & 2,610 & 2,090 & 350,000 \\
\hline 1946 & 1,440 & 27,700 & 125,000 & 41,400 & 21,200 & 53,800 & 8,780 & 1,960 & 3,060 & 8,390 & 2,760 & 2,430 & 297,000 \\
\hline 1947 & 2,160 & 6,820 & 219,000 & 242,000 & 54,800 & 30,500 & 7,270 & 8,660 & 6,150 & 11,800 & 5,020 & 3,380 & 597,000 \\
\hline 1948 & 3,010 & 2,980 & 72,100 & 247,000 & 118,000 & 74,000 & 36,500 & 16,600 & 1,540 & 8,360 & 8,730 & 3,090 & 592,000 \\
\hline 1949 & 1,510 & 1,860 & 23,400 & 69,600 & 41,500 & 11,400 & 1,940 & 258 & 1,270 & 5.680 & 4,510 & 1,760 & 165,000 \\
\hline 1950 & 357 & 1,530 & 17,600 & 503,000 & 72,000 & 43,400 & 15,100 & 13,400 & 1,140 & 4,570 & 6,340 & 2,770 & 681,000 \\
\hline 1951 & 3,190 & 3,070 & 73,000 & 381,000 & 264,000 & 73,900 & 43,500 & 30,200 & 26,900 & 31,700 & 14,300 & 10,800 & 956,000 \\
\hline 1952 & 5,730 & 40,700 & 234,000 & $1,860,000$ & 238,000 & 37,900 & 52,900 & 11,000 & 6,870 & 14,400 & 4,000 & 3,620 & $2,510,000$ \\
\hline 1953 & 3,760 & 5,040 & 33,400 & 91,400 & 247,000 & 291,000 & 54,700 & 15,800 & 5,190 & 13,100 & 10,100 & 7,800 & 778,000 \\
\hline 1954 & 4,310 & 31,100 & 29,100 & 350,000 & 90,400 & 68,600 & 18,000 & 39,200 & 18,300 & 51,800 & 8,740 & 6,740 & 716,000 \\
\hline 1955 & 2,200 & 2,430 & 113,000 & 683,000 & 571,000 & 120,000 & 271,000 & 19,800 & 8,030 & 19,700 & 2,980 & 3,010 & $1,820,000$ \\
\hline 1956 & 2,050 & 2,660 & 63,400 & 146,000 & 69,700 & 30,400 & 27,200 & 16,500 & 5,660 & 8,970 & 4,960 & 1,830 & 380,000 \\
\hline 1957 & 1,300 & 3,300 & 72,600 & 139,000 & 74.400 & 24,800 & 4,400 & 3,840 & 4,980 & 10,900 & 5,340 & 3,540 & 348,000 \\
\hline 1958 & 2,070 & 6,420 & 109,000 & 287,000 & 26,600 & 18,600 & 5,840 & 1,850 & 1,690 & 5,260 & 3,380 & 5,220 & 474,000 \\
\hline 1959 & 2,610 & 2,530 & 224,000 & 110,000 & 48,300 & 106,000 & 14,400 & 1,990 & 3,610 & 16,600 & 4,520 & 5,980 & 540,000 \\
\hline 1960 & 3,570 & 6,560 & 420,000 & 112,000 & 83,400 & 13,300 & 5,340 & 2,650 & 1,480 & 2,940 & 2,410 & 2,050 & 656,000 \\
\hline 1961 & 2,330 & 2,980 & 80,200 & 16,900 & 23,200 & 13,900 & 492 & 928 & 1,620 & 3,400 & 2,590 & 855 & 149,000 \\
\hline 1962 & 2,590 & 5,790 & 93,700 & 116,000 & 29,700 & 55,700 & 114,000 & 2,930 & 4,090 & 6,520 & 1,840 & 1,850 & 435,000 \\
\hline 1963 & 855 & 61,600 & 119,000 & 53,100 & 17,800 & 45,700 & 28,100 & 4,230 & 3,340 & 2,290 & 1,050 & 719 & 338,000 \\
\hline 1964 & 1,070 & 1,580 & 7,180 & 49,900 & 106,000 & 76,100 & 18,300 & 4,000 & 4,920 & 8,230 & 7,450 & 2,640 & 287,000 \\
\hline 1965 & 947 & 22,100 & 34,500 & 578,000 & 353,000 & 137,000 & 99,800 & 14,500 & 35,800 & 22,000 & 12,500 & 9,980 & $1,320,000$ \\
\hline 1966 & 1,500 & 3,210 & 329,000 & 144,000 & 53,800 & 47,100 & 22,300 & 16,100 & 3,430 & 8,780 & 4,220 & 3,500 & 637,000 \\
\hline 1967 & 4,010 & 8,100 & 185,000 & 424,000 & 514,000 & 84,400 & 21,100 & 10,500 & 12,900 & 16,000 & 7,750 & 5,060 & $1,290,000$ \\
\hline 1968 & 11,700 & 19,300 & 178,000 & 46,400 & 42,700 & 34,200 & 12,900 & 14,600 & 21,500 & 19,500 & 9,310 & 5,690 & 416,000 \\
\hline 1969 & 2,630 & 4,200 & 156,000 & 508,000 & 111,000 & 47,300 & 87,600 & 8,180 & 4,590 & 19,400 & 10,500 & 8,510 & 969,000 \\
\hline 1970 & 1,920 & 6,590 & 64,000 & 317,000 & 359,000 & 98,800 & 29,900 & 13,100 & 7,910 & 10,200 & 9,460 & 4,450 & 922,000 \\
\hline
\end{tabular}


Table 16. Synthesized streamflow volumes for Milk River at Vandalia diversion dam, Montana, 1928-89, in acre-feet (Continued)

\begin{tabular}{|c|c|c|c|c|c|c|c|c|c|c|c|c|c|}
\hline YEAR & JAN. & FEB. & MAR. & APR. & MAY & JUNE & JULY & AUG. & SEPT. & OCT. & Nov. & DEC. & TOTAL \\
\hline 1971 & 29,800 & 168,000 & 78,000 & 226,000 & 80,800 & 40,900 & 11,400 & 5,720 & 4,120 & 6,280 & 4,870 & 812 & 57,000 \\
\hline 1972 & 301 & 633 & 250,000 & 60,100 & 58,200 & 74,400 & 17,800 & 12,600 & 8,960 & 13,400 & 5,280 & 1,180 & 12,000 \\
\hline 1973 & 1,940 & 3,480 & 60,000 & 43,500 & 32,500 & 28,000 & 6,950 & 3,760 & 3,590 & 1,840 & 2,210 & 1,850 & 190,000 \\
\hline 1974 & 20,400 & 9,410 & 120,000 & 302,000 & 296,000 & 115,000 & 31,300 & 26,500 & 10,900 & 10,600 & 8,210 & 10,500 & 960,000 \\
\hline 1975 & 3,190 & 1,990 & 8,890 & 259,000 & 580,000 & 183,000 & 84,300 & 42,900 & 22,700 & 33,900 & 8,130 & 11,500 & $1,240,000$ \\
\hline 1976 & 15,500 & 33,700 & 512,000 & 180,000 & 46,500 & 51,500 & 33,100 & 19,100 & 2,050 & 6,000 & 4,010 & 3,390 & 907,000 \\
\hline 1977 & 3,140 & 15,600 & 23,600 & 36,700 & 17,600 & 9,340 & 5,560 & 4,640 & 3,750 & 39,800 & 2,120 & 2,290 & 164,000 \\
\hline 1978 & 2,490 & 2,430 & 499,000 & 417,000 & 196,000 & 42,000 & 72,100 & 21,300 & 37,600 & 10,300 & 9,200 & 6,780 & $1,320,000$ \\
\hline 1979 & 3,910 & 5,410 & 609,000 & 437,000 & 289,000 & 38,300 & 44,700 & 8,950 & 4,710 & 4,740 & 4,970 & 6,980 & $1,460,000$ \\
\hline 1980 & 2,470 & 5,000 & 64,300 & 96,800 & 26,400 & 26,300 & 7,270 & 8,090 & 6,630 & 7,620 & 5,280 & 3,570 & 260,000 \\
\hline 1981 & 5,130 & 164,000 & 34,200 & 17,400 & 49,400 & 37,100 & 15,000 & 3,990 & 2,590 & 4,880 & 4,680 & 2,690 & 341,000 \\
\hline 1982 & 904 & 33,200 & 167,000 & 438,000 & 136,000 & 184,000 & 33,500 & 10,200 & 4,590 & 11,200 & 6,040 & 4,270 & $1,030,000$ \\
\hline 1983 & 3,810 & 6,800 & 46,600 & 43,200 & 63,000 & 13,000 & 72,900 & 8,500 & 4,670 & 3,390 & 2,690 & 1,130 & 270,000 \\
\hline 1984 & 2,290 & 11,700 & 29,300 & 25,700 & 10,800 & 13,700 & 2,020 & 3,540 & 2,910 & 861 & 2,340 & 1,160 & 106,000 \\
\hline 1985 & 467 & 9,290 & 34,800 & 107,000 & 32,600 & 16,600 & 2,980 & 3,630 & 10,700 & 18,300 & 6,320 & 2,210 & 245,000 \\
\hline 1986 & 6,200 & 102,000 & 518,000 & 36,700 & 309,000 & 52,800 & 28,900 & 5,520 & 433,000 & 120,000 & 31,700 & 30,400 & $1,680,000$ \\
\hline 1987 & 12,200 & 31,500 & 181,000 & 135,000 & 26,900 & 19,300 & 24,700 & 16,500 & 8,410 & 5,670 & 6,910 & 4,010 & 472,000 \\
\hline 1988 & 769 & 1,910 & 20,700 & 36,200 & 16,100 & 10,800 & 12,100 & 3,710 & 1,340 & 338 & 1,670 & 1,360 & 107,000 \\
\hline 1989 & 898 & 705 & 65,700 & 63,200 & 35,500 & 45,600 & 13,700 & 3,900 & 6,060 & 2,660 & 8,660 & 5,610 & 252,000 \\
\hline
\end{tabular}


Table 17. Synthesized streamflow volumes for Milk River at mouth, Montana, 1928-89, in acre-feet

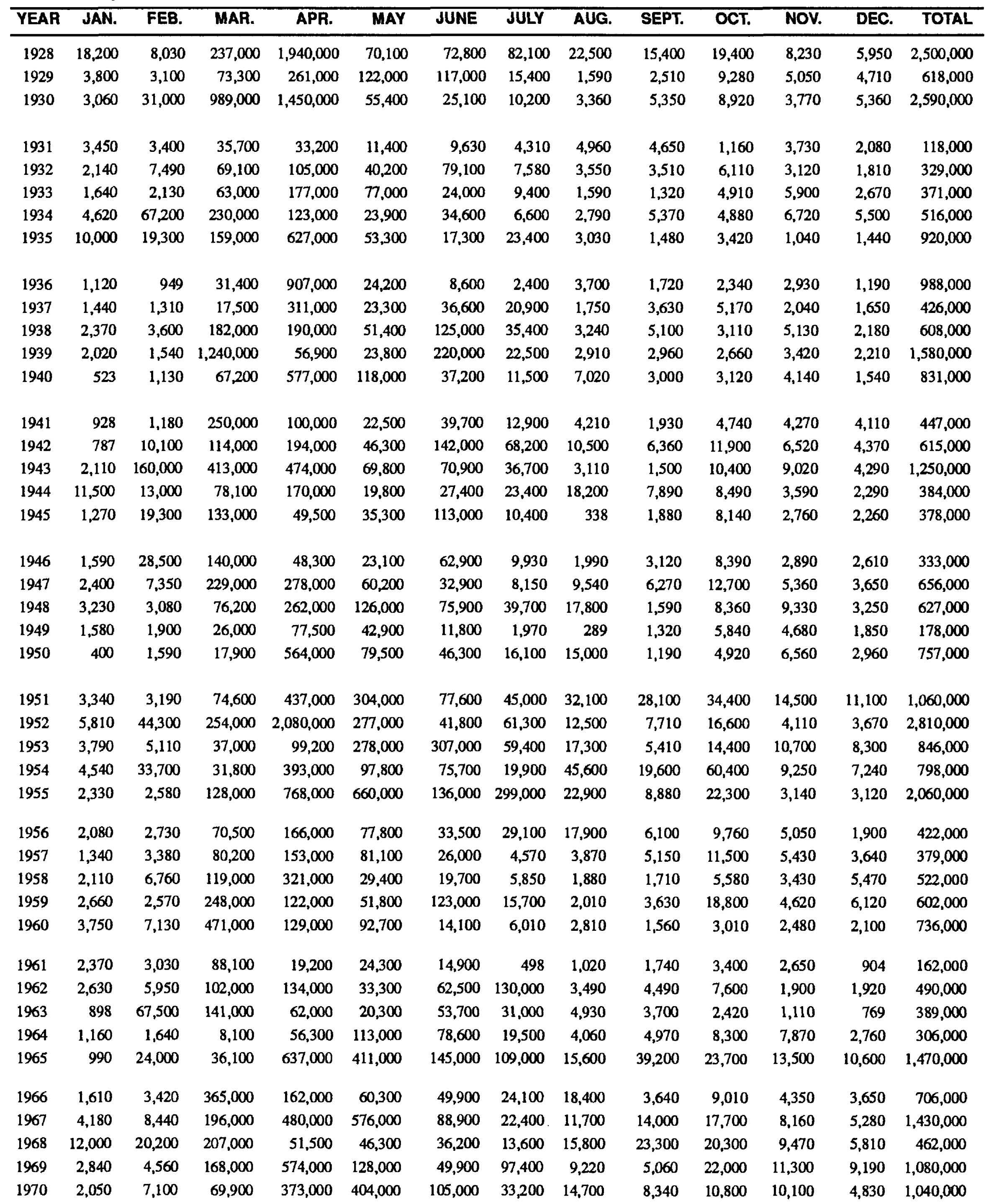


Table 17. Synthesized streamflow volumes for Milk River at mouth, Montana, 1928-89, in acre-feet (Continued)

\begin{tabular}{|c|c|c|c|c|c|c|c|c|c|c|c|c|c|}
\hline $\begin{array}{l}\text { YEAR } \\
\text { Y }\end{array}$ & JAN. & FEB. & MAR. & APR. & MAY & JUNE & JULY & AUG. & SEPT. & OCT. & NOV. & DEC. & TOTAL \\
\hline 1971 & 32,900 & 185,000 & 85,200 & 257,000 & 90,000 & 43,900 & 12,200 & 6,200 & 4,180 & 6,670 & 5,080 & 867 & 729,000 \\
\hline 1972 & 338 & 708 & 277,000 & 64,800 & 62,700 & 79,100 & 19,000 & 13,400 & 9,670 & 14,900 & 5,580 & 1,250 & 548,000 \\
\hline 1973 & 1,990 & 3,600 & 68,500 & 48,300 & 35,900 & 31,900 & 7,940 & 4,060 & 3,640 & 1,960 & 2,470 & 2,030 & 212,000 \\
\hline 1974 & 22,300 & 10,600 & 129,000 & 352,000 & 326,000 & 119,000 & 34,200 & 28,900 & 11,600 & 11,900 & 8,940 & 11,000 & $1,070,000$ \\
\hline 1975 & 3,540 & 2,160 & 9,650 & 291,000 & 644,000 & 188,000 & 89,200 & 45,500 & 24,700 & 38,500 & 8,540 & 12,300 & 0,000 \\
\hline 1976 & 16,900 & 37,800 & 598,000 & 209,000 & 51,400 & 58,900 & 37,900 & 21,700 & 2,340 & 6,510 & 4,180 & 3,600 & $1,050,000$ \\
\hline 1977 & 3,420 & 17,000 & 26,200 & 41,400 & 19,700 & 10,200 & 6,020 & 5,040 & 3,990 & 47,800 & 2,310 & 2,580 & 5,000 \\
\hline 1978 & 2,800 & 2,710 & 553,000 & 464,000 & 217,000 & 44,200 & 79,200 & 22,000 & 40,500 & 11,000 & 10,200 & 7,560 & 0,000 \\
\hline 1979 & 4,400 & 5,860 & 644,000 & 500,000 & 327,000 & 41,200 & 50,200 & 10,100 & 5,050 & 5,170 & 5,650 & 7,780 & $1,610,000$ \\
\hline 1980 & 2,790 & 5,280 & 70,600 & 110,000 & 28,000 & 27,800 & 7,720 & 8,690 & 7,010 & 8,150 & 5,910 & 3,870 & 286,000 \\
\hline 1981 & 5,580 & 198,000 & 38,100 & 18,600 & 51,200 & 39,400 & 16,200 & 4,110 & 2,640 & 4,910 & 5,000 & 2,940 & 387,000 \\
\hline 1982 & 1,050 & 37,900 & 194,000 & 495,000 & 154,000 & 204,000 & 37,500 & 11,300 & 5,060 & 12,300 & 6,720 & 4,730 & $1,160,000$ \\
\hline 1983 & 4,230 & 7,640 & 53,600 & 49,900 & 71,400 & 14,300 & 80,300 & 9,460 & 4,750 & 3,710 & 3,000 & 1,300 & 304,000 \\
\hline 1984 & 2,550 & 12,800 & 32,600 & 29,100 & 11,800 & 15,600 & 2,040 & 3,550 & 2,910 & 873 & 2,580 & 1,300 & 118,000 \\
\hline 1985 & 53 & 10,300 & 38,700 & 123,000 & 35,600 & 17,900 & 3,010 & 3,750 & 10,900 & 19,600 & 6,880 & 2,430 & 273,000 \\
\hline 1986 & 6,610 & 110,000 & 590,000 & 40,600 & 342,000 & 55,800 & 32,100 & 5,970 & 473,000 & 134,000 & 35,100 & 33,700 & $1,860,000$ \\
\hline 1987 & 13,500 & 37,000 & 208,000 & 154,000 & 29,300 & 21,200 & 27,900 & 18,100 & 8,840 & 6,020 & 7,630 & 4,460 & 536,000 \\
\hline 1988 & 867 & 2,070 & 22,800 & 39,700 & 17,500 & 11,800 & 14,000 & 3,740 & 1,340 & 338 & 1,870 & 1,550 & 118,000 \\
\hline 1989 & 1,040 & 822 & 73,400 & 71,400 & 38,900 & 49,000 & 14,300 & 4,000 & 6,190 & 2,710 & 9,200 & 5,950 & 277,000 \\
\hline
\end{tabular}

